\title{
DE SU PROPIA VOZ, EL IMPACTO DEL DUELO CULTURAL Y LUTO MIGRATORIO EN LATINAS VIVIENDO EN CANADÁ. \\ (IN THEIR OWN VOICES, THE IMPACT OF CULTURAL BEREAVEMENT AND GRIEF MIGRATION ON LATINAS IN CANADA)
}

\author{
by
}

Covadonga Blanco BSW, Ryerson University, 2019

\author{
A Major Research Paper \\ Presented to Ryerson University \\ in partial fulfillment of the requirements for the degree of \\ Master of Social Work \\ in the program of \\ Social Work
}

Toronto, Ontario, Canada, 2020

(C) Covadonga Blanco, 2020 


\section{AUTHOR'S DECLARATION}

I hereby declare that I am the sole author of this MRP. This is a true copy of the MRP, including any required final revisions.

I authorize Ryerson University to lend this MRP to other institutions or individuals for the purpose of scholarly research

I further authorize Ryerson University to reproduce this MRP by photocopying or by other means, in total or in part, at the request of other institutions or individuals for the purpose of scholarly research.

I understand that my MRP may be made electronically available to the public. 


\title{
DE SU PROPIA VOZ, EL IMPACTO DEL DUELO CULTURAL Y LUTO MIGRATORIO EN LATINAS VIVIENDO EN CANADÁ. (IN THEIR OWN VOICES, THE IMPACT OF CULTURAL BEREAVEMENT AND GRIEF MIGRATION ON LATINAS IN CANADA)
}

\author{
Covadonga Blanco \\ Master of Social Work, 2020 \\ School of Social Work \\ Ryerson University
}

\begin{abstract}
The lives of immigrants are forever changed by the many losses that they leave behind during their migration journey. Through the use of poetry, this qualitative research draws upon narrative and art-based approaches to explore the effects of cultural bereavement and migratory grief on the identity and well-being of Latinas Immigrants. Three Latina women shared their grief stories through poetry, disrupting preconceived notions of representation in Canada. Under the lens of Latino critical race theory, issues of race, culture, and gender that intersect to dictate Latinas experiences with migratory grief were analyzed. Findings yielded five theoretical concepts: The cumulation of grief, losses and stress guides process of acculturation, cultural values dictate Latinas settlement, changes in identity, struggle with oppressive systems and resistance and resilience. The result of this research will guide the reader to understand immigrants' experiences with the invisible yet powerful pain of grief associated with migration.
\end{abstract}

\section{Keywords}

Migratory grief, cultural bereavement, Latinas, Latin America, poetry, Immigration, losses. Migration, identity. 


\title{
DE SU PROPIA VOZ, EL IMPACTO DEL DUELO CULTURAL Y LUTO MIGRATORIO EN LATINAS VIVIENDO EN CANADÁ. (IN THEIR OWN VOICES, THE IMPACT OF CULTURAL BEREAVEMENT AND GRIEF MIGRATION ON LATINAS IN CANADA)
}

\author{
Covadonga Blanco \\ Maestria en Trabajo Social, 2020 \\ Escuela de Trabajo Social \\ Universidad de Ryerson
}

\begin{abstract}
O
La vida de los inmigrantes cambia para siempre debido a las pérdidas que enfrentan al dejar sus lugares de origen y por las dificultades que enfrentan durante su camino migratorio. Mediante el uso de la poesía, esta investigación cualitativa usa una combinación de arte con narrativa para explorar los efectos del duelo cultural y el luto migratorio en la identidad y el bienestar de los inmigrantes Latinos. Tres mujeres Latinas compartieron sus historias de duelo a través de poemas, rechazando ideas preconcebidas acerca de la representación en Canadá. Bajo la lente de la teoría crítica de la raza Latina, se analizaron la interseccionalidad de raza, cultura y género y su influencia en dictaminar las experiencias de las mujeres Latinas con el duelo migratorio y el luto cultural. Los resultados arrojaron cinco conceptos teóricos: la acumulación de pérdidas y el estrés guían el proceso de aculturación, los valores culturales dictan el asentamiento de las Latinas, existen cambios en la identidad, hay lucha con sistemas opresión y la resistencia y la resiliencia. El resultado de esta investigación guiará al lector a comprender las experiencias de los inmigrantes con el invisible pero poderoso duelo asociado con la migración.
\end{abstract}

\section{Palabras clave}

Dolor migratorio, luto cultural, Latinas, América Latina, poesía, inmigración, pérdidas. Migración, duelo cultural, identidad. 


\section{ACKNOWLEDGEMENTS/ AGRADECIMIENTOS}

\section{To Ken Moffatt}

Thank you for your patience, feedback and ongoing encouragement which motivated me to go deeper in exploring this work. Thank you for showing the great flexibility to accommodate my learning needs and your heart-felt effort in guiding me to see my strengths. I greatly appreciated the opportunity to learn from you in each moment we had together.

\section{A todas las Latinas que participaron en esta investigación;}

Gracias por abrir su corazón, y compartir sus dolorosas experiencias de dejar su país, su lengua, su cultura y sus familias. Gracias por permitirnos entender un poco mejor el efecto del duelo migratorio en sus vidas y de demostrarnos su perseverancia y fortaleza por salir adelante.

To all the Latinas who participated in this research

Thank you for opening your heart, and sharing your experiences of leaving your country, your language, your culture and families. Thank you for allowing us to understand a little better the effect of migratory mourning on your lives and for showing us your perseverance and strength to move forward.

\section{A Froilán Blanco del Peral ...el emigrante}

Quien fuera pensar que el camino migratorio que empezó contigo iba hacer yo quien lo siguiera. Esa senda que tu abriste ahora la amplio al venirme al Canadá. Al seguir tus pasos como inmigrante, comprendo y entiendo tu dolor de dejar lo que más querías; a tu España querida, tu familia, tus costumbres. Y a pesar de estar en un país extraño, lo hiciste tuyo sin dejar a un lado tu apego a tu Lores, tu tierra. Admiro tú Fortaleza, entiendo tu duelo y aprecio tus sacrificios. 
To Froilán Blanco del Peral... the immigrant

Whoever thought that the migratory path that began with you, it would have been me who followed it. I had widened the path that you opened when I immigrated to Canada. As I follow your steps as an immigrant, I understand your pain of leaving what you loved most; your beloved Spain, your family, your customs. Even though you were in a strange country, you made it yours without leaving aside your attachment to your Lores, your land. I admire your strength; I understand your grief and I appreciate your sacrifices. 


\section{DEDICATION/DEDICATORIA}

A las mujeres Latinas de mi vida; mi Abue Eloísa, mi Mama, y mi amada Tia Yola.

Que han sido mujeres sabias, guerreras, luchadoras, fuertes y de "armas tomar", que nada las ha vencido ni las agobia lo suficiente como para perder las esperanzas y seguir luchando. Que, con sus experiencias de vida y su ejemplo de sabiduría, fortaleza, y ternura no solo han definido mi existencia si no que me han enseñado hacer frente a los obstáculos con la cabeza en alto.

To the Latina women in my life; my Grandmother Eloisa, my Mama, and my beloved Aunt Yola.

Wise women, warriors, fighters, strong and of "weapons to take", that nothing overcomes or overwhelms them enough to lose hope and continue fighting. That with their life experiences and their example of wisdom, strength, and tenderness they have not only defined my existence but they have also taught me to face obstacles with my head held high.

This research is dedicated to my beautiful children; Vanessa my greatest teacher, you have taught me what it means unconditional love and to Luis; mi fino, you are the most beautiful story that destiny wrote in my life.

I hope all the time, effort, and sacrifice I have made to accomplish this goal will serve as an example that you should always look to the sky and set your goals high and that no matter what you want to accomplish in life never, ever give up.

Esta investigación está dedicada a mis hermosos hijos; Vanessa mi mejor maestra, me has enseñado lo que significa amor incondicional y para Luis mi fino, eres la historia más hermosa que el destino escribió en mi vida. 
Espero que todo el tiempo, el esfuerzo y el sacrificio que he hecho para lograr este objetivo sirvan como un ejemplo de que siempre deben mirar al cielo y establecer sus objetivos altos y que no importa lo que quieran lograr en la vida, nunca, nunca deben darse por vencidos.

También dedico esta investigación a mi amado abuelo Roberto...

Un hombre amoroso, recto con altos valores y moral; su ejemplo de amor, perseverancia, fortaleza y honradez es parte de todo lo que hago.

I also dedicate this research to my beloved grandfather Roberto...

A loving, righteous man with high values and morals, his example of love, perseverance, strength and honesty is part of everything I do.

Finally, to God, the one that has guide me and sustain me during my migration journey, he has strengthened my soul and walked with me in dark moments shining his light to follow his path... 


\section{TABLE OF CONTENTS}

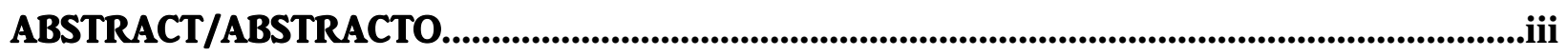

ACKNOWLEDGEGMENT........................................................................................................................

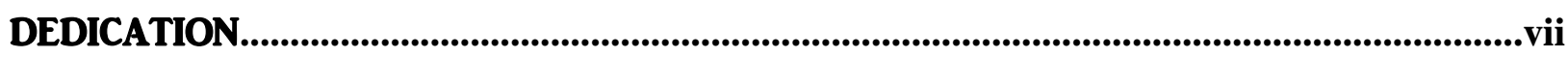

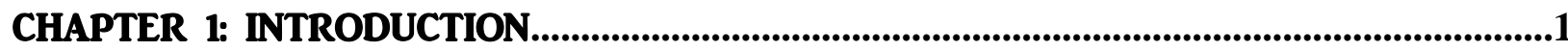

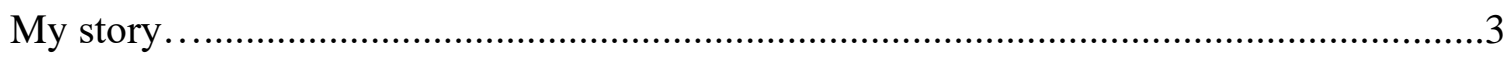

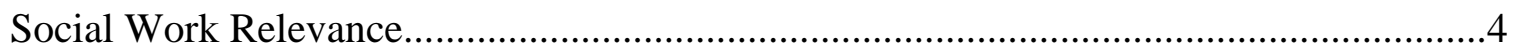

CHAPTER 2: LITERATURE REVIEW ............................................................................................6

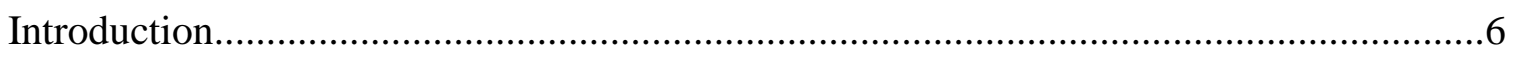

Overview of Latin American Immigration in Canada......................................................

Grief and Loss Perspectives ..............................................................................10

Migratory Grief Perspectives...............................................................................13

Migratory Grief \& Latinos..............................................................................14

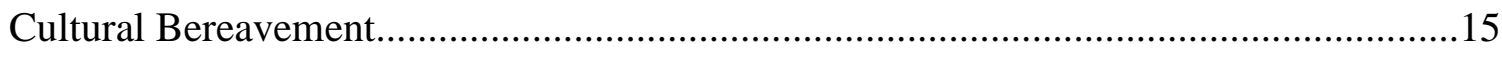

Cultural Bereavement \& Latinos Values.............................................................16

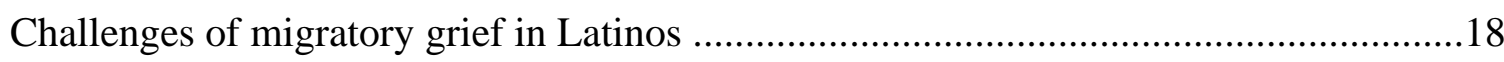

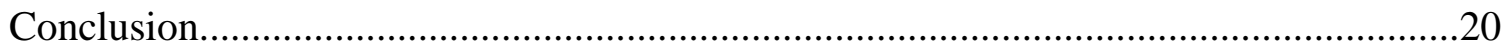

CHAPTER 3: THEORETICAL APPROACH...............................................................................23

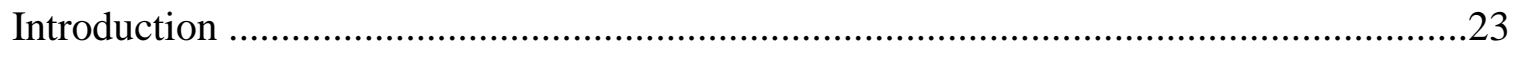

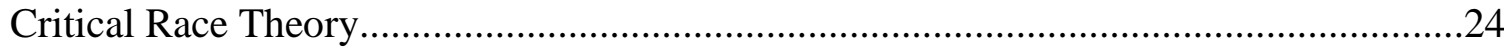

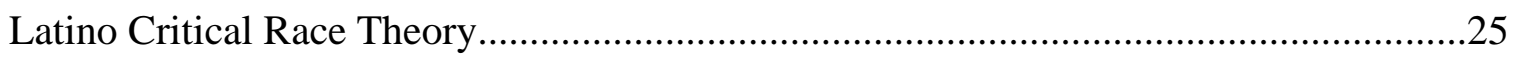

Tenets of Latino Critical Race Theory..................................................................26 
Latinas stories under Latino Critical Race lens..................................................29

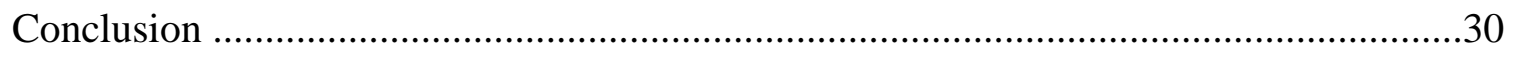

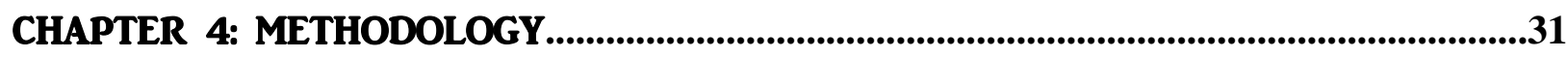

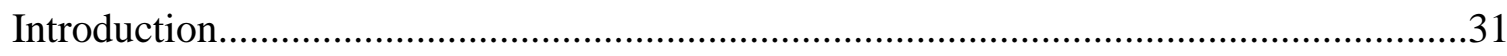

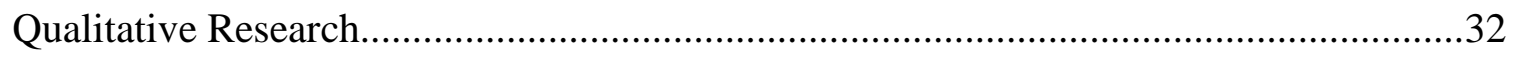

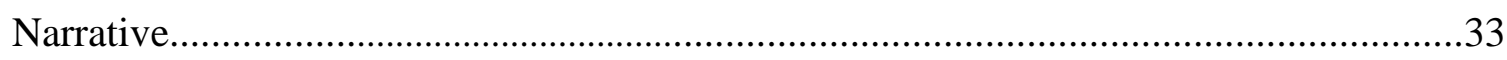

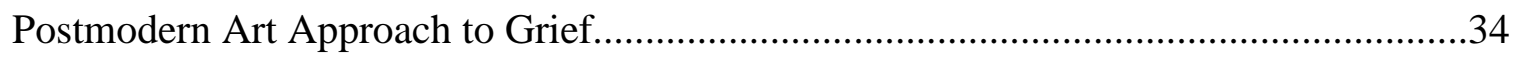

Feminist Postmodern art- based approach to Grief............................................35

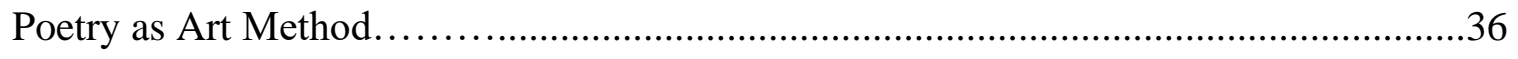

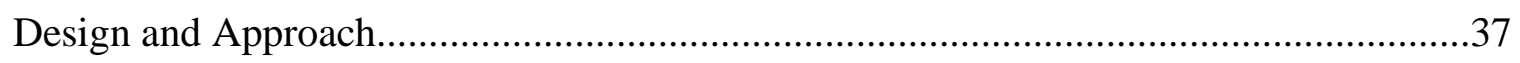

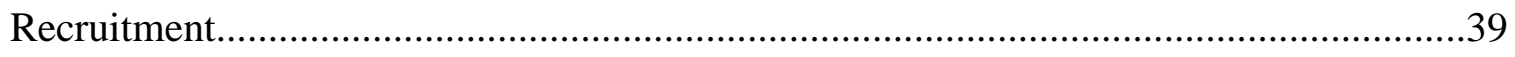

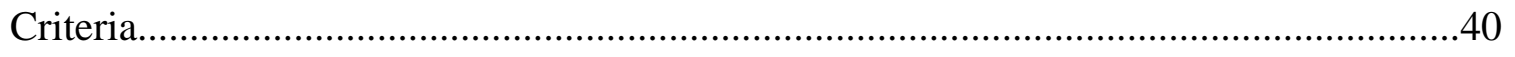

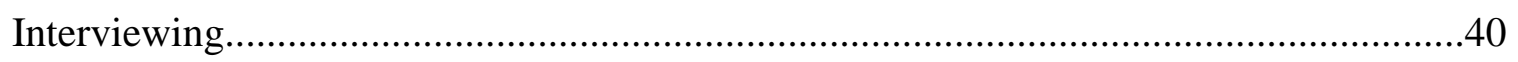

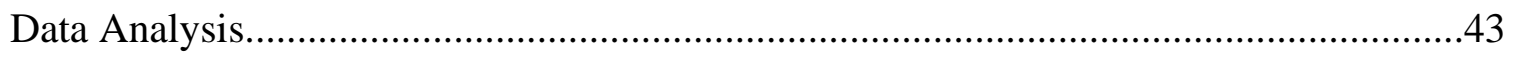

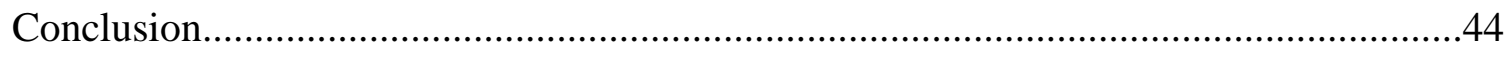

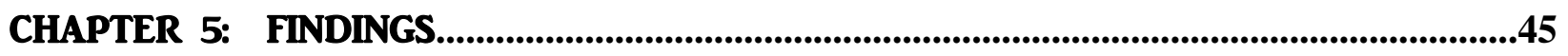

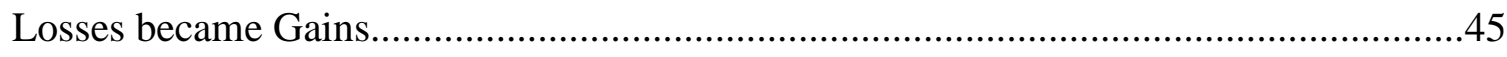

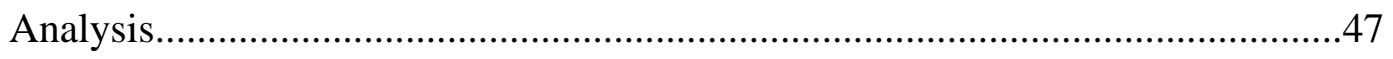

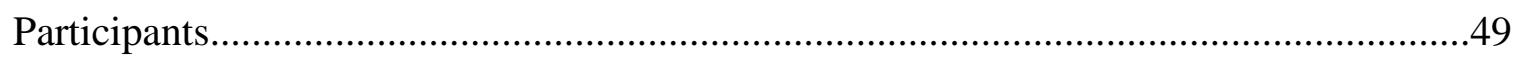

Participant 'A' - Alinne \& The Labyrinth of Pain..........................................49

Participant 'B' - Blanca \& Doble Identity..................................................49

Participant ' $\mathrm{C}$ '- Carla \& Breaking out of my Cocoon.....................................50

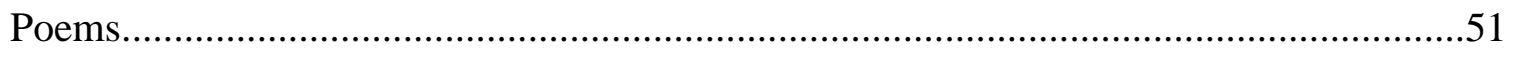




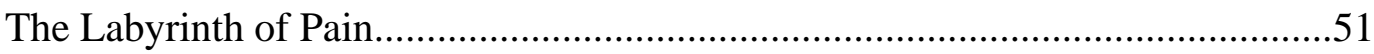

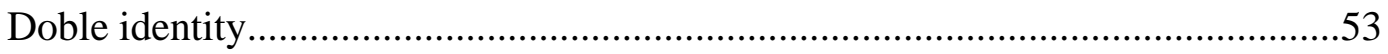

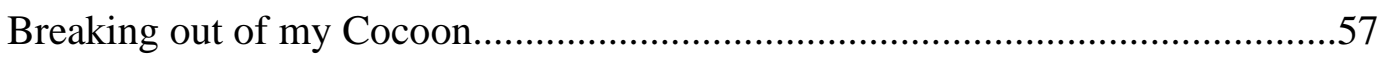

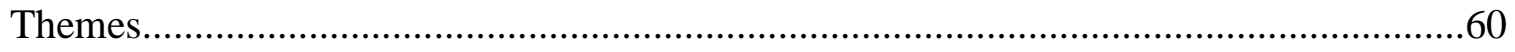

The cumulation of grief, losses and stress guide migration..............................61

Cultural Values dictate Latinas settlement.....................................................66

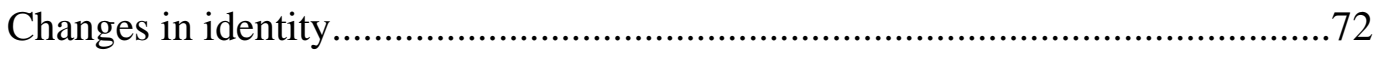

Struggle with oppressive systems...........................................................75

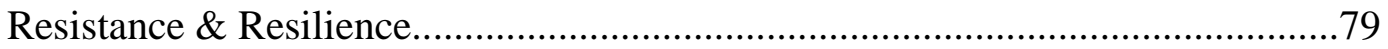

CHAPTER 6: DISCUSSION \& CONCLUSION............................................................................83

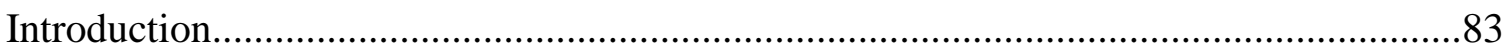

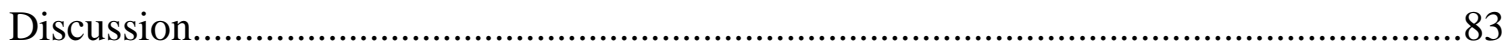

The cumulation of grief, losses and stress guide migration..............................84

Cultural Values dictate Latinas settlement..................................................8

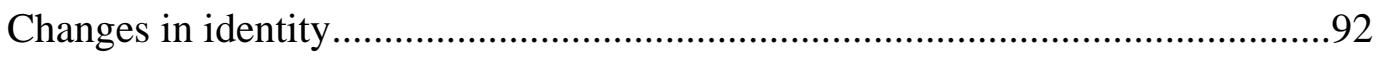

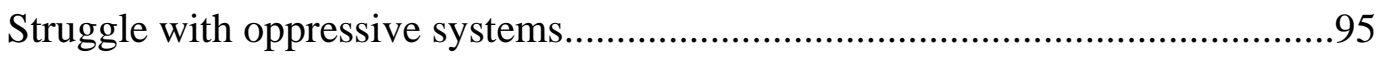

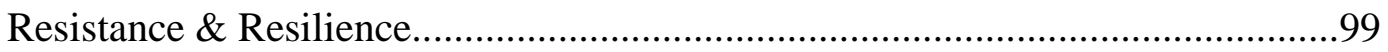

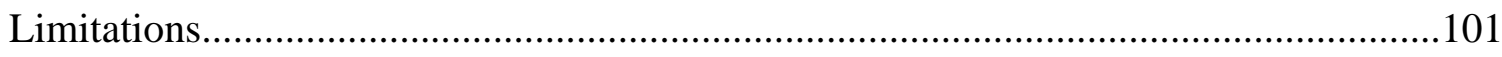

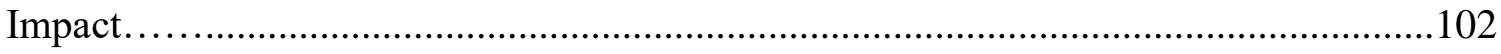

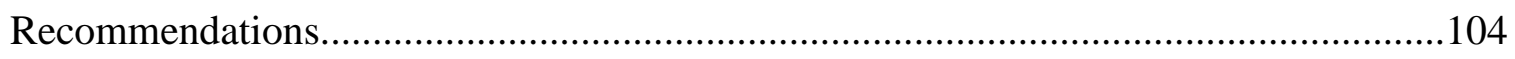

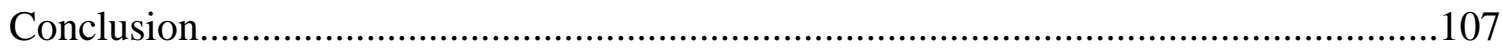

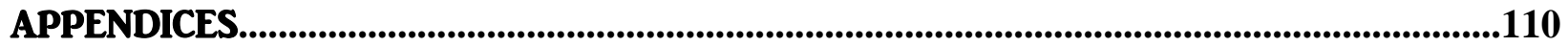

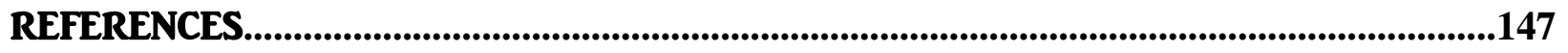




\section{LIST OF APPENDICES}

Appendix A - Recruitment Email in English \& Spanish

Appendix B - Consent form in English.

Appendix C - Consent form in Spanish

Appendix D - Interview Guide in English

Appendix E - Interview Guide in Spanish

Appendix F - List of Resources.in Spanish \& English 


\section{CHAPTER 1 \\ INTRODUCTION}

They have no idea what it is like to lose home

at the risk of never finding home again,

have your entire life split between two lands

and become the bridge between two countries.

- "First Generation Immigrant" by Rupi Kaur (Kaur,2016)

Accordingly, to writer Joan Didion (1979), "we tell ourselves stories to live," stories are windows to understanding. The more complex those stories are, the higher our knowledge becomes, those stories awaken us to "the existence and experience of others, especially those others who are perceived to be different from us" (Holman, 2016, p.230). One of those windows to understanding the existence of others is the story of migratory grief and the cultural bereavement of Latinos. Latinos migrated from different countries in North, Central and South America from diverse motives and reasons, and their lives are forever changed by their migration journey (Perez \& Arnold-Berkovits, 2018).

My research topic studies the impact of migratory grief and cultural bereavement in the well-being as well as the identity of Latina Immigrants. This research contributes to understanding the specific needs and challenges that newcomers have to face when immigrating to Canada. Through a qualitative narrative and art-based design, participants share their stories of grief and migration through poetry. This approach to research gives value to the poetic expression of participants while recognizing the influences of their experiences in the research process.

In Canada, the Latin American population has been ignored in academia and research, thus neglecting the power of this population (Glaser, 2017). This research under the lens of Latino 
Critical Race Theory (LatCrit) brings to the light how issues of subordination and race as a social construction are used in Canada to oppress and control Latinas' experiences with migration, loss and grief (Yosso, 2005).

This study gives voice to a selected number of participants as they share through poetry that expresses their lived experiences with migratory grief and cultural bereavement. The purpose of this study is to draw upon a Critical Race and Latina Critical Race lens to take on a decolonized perspective in research and practice. The decolonized approach focuses on migratory grief to raise awareness of the losses and their outcomes on the identities and well-being of Latinas (Chatterjee, 2019).

I also present my poetic expression reflecting on migratory grief experience as a Latina immigrant in Canada, to use as a prelude to expanding the understanding of the social phenomena, to decolonize the research, and to support the narratives of the participants. This research aims to help Social Work to better understand the unique issues of this population so culturally competent social work practice and programs are created to serve better the Latin American diaspora community.

This research is divided into seven major sections. The first chapter presents an overview of the research topic, including the author's personal motivation to create this project and the relevance of the topic to social work. In the second chapter, a literature review summarizes the existing literature on migratory grief, cultural bereavement, losses related to migration, cultural values on the Latin American population are discussed. The third chapter introduces a summary of the theoretical frameworks of Critical Race Theory (CRT), under the lens of Latino Critical Race Theory (LatCrit) for this study. In the fourth chapter, the methodology used in this study is presented along with an overview of the design and approach to collect data. In the fifth chapter, 
the poems and findings obtained throughout this research are presented. Finally, in the sixth chapter, a discussion and conclusion are presented, along with the recommendations and implications for social work.

\section{My Story}

My motivation to create this project comes from my personal experience with migratory grief as a Latina immigrant as well as my professional experience as a grief counsellor working with newcomers and immigrants. Those experiences had sensitized me to the experiences of grief, bereavement and loss that immigrants faced when they migrate to Canada.

The inspiration for this narrative and art-based research took place while I began to critically reflect upon my past struggles as a Latina immigrant. I have had the opportunity to work in settlement services, social services, child welfare and grief support; those fields that appear to be very different have the commonality of migratory grief and loss. However, I noticed that migratory grief is not an issue that is openly addressed and that its invisibility persists.

Based on my personal experiences, I felt inclined to blend my interests in working in immigration/refuges settlement services with grief and loss into my research project. I want to take a step forward and to examine the cultural bereavement process associated with immigration under the lens of the Latin American population and to learn about the influence of unresolved grief in the identity of Latinas and their settlement process, cultural beliefs and identity.

During my application for my Masters in Social Work, I decided to do a research project regarding migratory grief in Latinas to confront and challenges academia and research practices that have mostly ignored the experiences of the Latin American diaspora in Canada (Glaser, 2017). I decided to attached my poem in my Master's application as an artistic expression of the type of 
research I wanted to pursue during my studies. It was at that moment that I understood that doing this study is my counter-story. In other words, the research is a way to resist but also to invite Latinas to cofacilitate research by narrating their experiences with migratory grief. As a LatCrit counter-story strategy, we reclaim our power and to seek liberation from oppressive structures (Delgado et al., 2017).

This research follows the qualitative tenet of locating as a researcher my values, and interests as a data collector. I present in chapter five of this study a poem that I wrote regarding my own experiences as a Latina immigrant with migratory grief and cultural bereavement, illustrating and summarizing my stance as a Latina immigrant in Canada. As a Latina immigrant, a Social Worker, and a researcher, I embrace the opportunity to gather new knowledge and meanings regarding migratory grief. I feel honoured by the opportunity to hear from my fellow Latinas immigrants that willing to share their migratory grief stories.

\section{Social Work Relevance}

This study is relevant to social work because of its potential to assist social workers in addressing the unique experiences of this population. Social workers can assist in the advocacy and implementation of grief support services that are culturally designed to support Latina immigrant women through their migratory journey.

This research is relevant to Canadian Social Work practice due to its design to address and bring to the light in an anti-oppressive manner the unique issues of the Latin American community. Anti-oppressive research identifies the oppression of minorities groups, "exposing imbalances on power relationships by recognizing that knowledge is socially constructed and political” (Potts \& Brown, 2015, p. 262) In this project I challenge notions of who construct knowledge by facilitating 
research that can help Latinas in reclaiming their power. This study can be used as a first step to see the Latin America community proportionally represented in practice, trough an anti oppressive research and academia in Canada that until now has been invisible in the field of Social Work

Finally, this project can contribute to postmodern social work by bringing poetry into research to challenge the main discourses of what constitutes research based on the usually strict expectations of how research should be presented. The nature of the participants' experience in research is often taken for granted, by recognizing the resilience of minorities (Latinas) and their capacities in facing adversity, the project will enable the researcher and further social work research to engage more consciously with the participants through their poetic expression. Poetry can be more than a way to gather data; it can create a therapeutic process for the participants (Wakeman, 2015). 


\title{
CHAPTER 2
}

\section{LITERATURE REVIEW}

\author{
Living here Is wanting to be there. \\ Being there Is wanting to be here. \\ This is confusing. \\ I don't know where I want to be. \\ If I am here, I have to learn English. \\ If I'm there, I have to learn to survive. \\ I don't know where I want to be. \\ - "Living Here" by Carmen (Christoph, 2014)
}

\section{Introduction}

The purpose of this literature review is to examine the experiences of Latinas with grief due to migration and to study the effects of cultural bereavement in their well being. The objective through my research is to contribute to center Latin American identities in Canadian social work research and practice. The question guiding this review is about "How do migratory grief and cultural bereavement impact the identity and well being of Latinas immigrants in Canada?", parting from that question, this review gathers insight on how Latina women experience migratory grief. Furthermore, this literature review illustrates and serves as a guide to broaden the understanding of the complex processes that Latin American immigrants experience when faced with the reality of migratory grief while adapting to a new host culture.

In this literature review, the common factor is migratory grief. However, I have identified other themes that are present in research as migration, Latin American immigration, Latinas migration, acculturation, losses, cultural bereavement, Latino values and effects of migration in their identity, social support network. The literature review starts with an introduction of postmodern social work and art-based approaches in grief support as a base of the review. Then it summarizes the existing literature on migratory grief, cultural bereavement, losses on the Latin American immigrants, and their impact on the well being of Latina immigrant women. 


\section{Overview of Latin American Immigration in Canada}

Latin Americans are described as people that descend or origin from any Spanish-speaking country in America. Zea, Quezada, \& Belgrave (1994) defined "Latinos" as a no gender-specific term that represents all persons living in North America whose ethnic and cultural origins can be traced to all the Spanish speaking countries of Latin America (Mexico, Central American, South America and the Caribbean. However, it is essential to clarify that the terms "Latinos" or "Latin Americans" are not racial and are only used to describe ethnic and cultural origins. For example, these umbrella terms encompass Latinas, Afro-Hispanics, Indigenous Latin Americans, and they will be used to refer to Latin Americans that have immigrated to Canada. In this research, the terms "Latinos" and "Latin Americans" will be largely used interchangeably in this paper to describe them as a group, community, or diaspora.

The term "Latinos" will be used as a gender-neutral term to describe the Latin-American community instead of the new term Latinx that has been lately used by some North American scholars to replace the term Latinos. In North American research, the supporters of the term "Latinx" argue that aims to promote greater acceptance among non-binary Latinos. Although the use of is increasing, the controversy between scholars surrounding the term is intense.

The critics of the term "Latinx" and supporters of "Latinos" as a gender-inclusive term, argue that the term "Latinx" is too foreign for Latinos outside the United States and virtually nonexistent in any Spanish-speaking country (Patterson, 2017). Ramírez \& Blay (2016) have "expressed their worry that the misuse by those who do not understand the term Latinx will negate any positive social gains from acceptance of the term itself" (as cited in Patterson, 2017, p.12). Furthermore, Guerra \& Orbea (2015) argue that Latin American scholars see the imposition of the Latinx term as an Anglo-western "form of linguistic imperialism, that forces Anglo ideals upon a 
Spanish language in a way that does not grammatically or orally correspond with it ( pp.3) The replacement of the letters o's and a's with x's, in the word "Latinx" is reduced to be incomprehensible to any Spanish speaker.

The world Latinx becomes a North American attempt to impose an Anglo-western theory of gender by trying to distort, police and erase the Spanish language that is already a gendered inclusive language. Advocating for the erasure of gender in the world Latino in Spanish is to advocate for the erasure of Spanish, it genders inclusive words and Latin American culture" (Guerra \& Orbea, 2015; Hernández \& Torres, 2015; Salinas, 2020). This study counteracts Anglowestern ideologies regarding Latin American identities by selecting to use the term "Latinos" as a form to resist the imposition of Anglo-Saxon linguistic ideology that lacks cultural awareness towards Latin American diaspora its culture and language.

According to Bhugra \& Becker (2005), migration is the "process of going from one country, region or place of residence to settle in another." Due to a variety of circumstances, immigrants have to leave their countries and immigrate to other destinations that offer more stability and safety that their country of origin (p. 18).

North America is one of the top three destinations to immigrate in the world, due to persistent economic and demographic inequalities between the global south and the north. As a result of those issues, North America has become one of the favourite international migration destinations for countries in the global south, specifically for Latin America (Martin, 2008). In this paper, the term immigrant will be largely used. However, the term is not necessarily limited to people who have voluntarily moved from their home countries; it could include those with work, study permits, refugee claimant, refugee status or protected persons. 
The migratory journey "becomes a crucial piece in the psychology of those who undertake it” (Perry, 2010). For Latin American immigrants, that means leaving behind their country, family, relatives, traditions, customs and language. Doka (2002) argues that while it is commonly agreed that are many losses in migration, and those losses create a grief process. There still no fully understood how immigrants experience migratory grief due to their unique cultural values influencing their grief process. It is this lack of understanding that can influence migratory grief into a form of disenfranchised grief (Perry, 2010).

The Latino immigrant population has grown considerably in North America. In Canada, it has continued rising in the past decade, yet Latinos are one of the least studied immigrant population in this country. (Martin, 2008). The Latin American population in Canada by 2001, has grown considerably faster than the overall population up to thirty-two percent vs the only four percent of the overall population (Statistics Canada, 2001). The majority of Latinos live primarily in Ontario, most of them are foreign-born, relatively young, educated (holding an undergraduate or graduate degree), multilingual and able to converse in English and French, Canada's two official languages live primarily in Ontario (Statistics Canada, 2011)

When Latinos arrive in Canada, they have to leave their old life, to be able to build a new one in their host country. Research in the United States has shown that the migration journey of Latinos in North America brings grief, and a sense of isolation into their settlement process (Casado et al., 2010; Gonzalez; 2005; Perry, 2010).

Casado et al. (2010) argue that the losses and grief of Latinos associated with migration are neglected and ignored, and if they remain unprocessed can cause harmful effects to their identity and well being (Gonzalez, 2005). However, other studies argue that argues that for Latina women, their migration experiences are also influenced by their gender (Hondagneu-Sotelo, 1992: 
Renfroe, 2018) Latina is a gender-specific term that represents all people that identify as a woman whose origins can be traced to all Spanish-speaking countries of Latin American; Mexico, Central American, South America and Caribbean (Zea et al., 1994). The term Latinas or Latina women (used as the plural of Latina), will be used interchangeably in this paper to describe them as a gender-specific group.

Patriarchal structures in both Latin American culture and American culture intersect, shaping Latinas experiences with migratory grief. Those patriarchal structures put pressure on Latina immigrants to adjust to the new host country with little grief expression over their cultural and personal losses associated with migration (Renfroe, 2018, p.394). Those influences cause that Latina women find it more difficult to integrate fully and assimilate the culture and customs of the dominant society (Houben, 2012 p.17).

The majority of the research focused on Latinos and Latinas experiences with migratory grief in the United States. This writer was not able to find social work research in Canada studying migratory grief in Latinas. However, a Canadian study was found in the Immigrant \& Refugee Studies Journal. The study focuses on Latina women fleeing gender-related violence and their experiences within the Canadian immigration system. The study brings knowledge regarding some of the aspects of grief and loss that Latina encountered when immigrating to Canada (Bhuyan et al., 2016).

\section{Grief and Loss Perspectives}

Usually, in literature, grief and bereavement had been seen as a reaction to the death of a loved one. However, grief is multidimensional and encompasses different types of losses. Grief is defined as the process of reacting to the loss of someone or something. (Stroebe \& Blink, 2008). 
Rando (1984) described grief as the psychological, emotional, social and somatic reaction to a loss (as cited in Casado et al., 2010). Grief and bereavement literature had focused on the reaction to the death of a loved one. However, grief is multidimensional, encompassing different types of losses. Most importantly, grief is viewed as a response to the disruption of the griever's subjective representation of the world. That representation can include losses due to migration (Bonanno,2004; Casado \& Leung, 2001; Stroebe, \& Blink, 2008).

In literature, rigid grief models have been presented to understand the types and factors that influence grief, to classify grief in stages, to give grief specific characteristics, or to differentiated different types of grief. However, some studies have criticized the rigidity of some stage models, although they recognized their contribution to inform specific bereavement reactions. Researchers argue that models are rigid and linear, minimizing the fluidity, duality and competitivity of grief experience (Bonanno \& Kaltman, 2001; Stroebe et al., 2017; Worden, 1982; Wortman et al.,1993).

Research has demonstrated that grief is not linear as it is commonly represented (Parkes,1996; Stroebe, \& Blink, 2008; Stroebe et al., 2017; Worden, 1982; Wortman et al., 1993). Furthermore, the literature had shown that in the domain of grief, there are no established stages which an individual move to resolve the grief (Bonanno, 2004; Casado \& Leung, 2001; Parkes, 1996; Stroebe, \& Blink, 2008; Stroebe et al., 2017).

Losses have many meanings depending on culture and social location. The process of losing someone or something is also complex. Research shows that losses are dependent on many factors and are divide into primary and secondary losses (Casado \& Leung, 2001; Gonzalez, 2005; Rando, 1993). 
Primary loss refers to the loss of a loved one and secondary losses (Casado et al., 2010; Casado \& Leung, 2001; Gonzalez, 2005). This research will focus on the multiple types of secondary losses due to migration (Rando, 1993).

Secondary loss can is divided into two types of losses:

a) Physical losses: which refer to tangible loss, such as access to family, house, a country or a job.

b) Symbolic loss: Involves intangible aspects of our lives that are necessary like loss of a homeland, family ties, language, culture and identity aspects of our lives that are vital for the well being of a person (Casado et al., 2010; Casado \& Leung, 2001).

Rando (1984), states that grief is not only a reaction to a loss, but it is intertwined with the multiple losses that convey grief (as cited in Casado et al., 2010). The intensity of grief is relative to the magnitude of the perceived loss. It differs depending on "how the bereaved perceives that loss and the importance of what is being lost" (Gonzalez, 2005, p.4). Scrutton (1995) argued that loss by death, maybe be the most ultimate lost, however, it is not the only loss that initiates the grief process, "other multiple secondary losses trigger a grief response" (as cited in Casado et al., 2010, p.4)

In literature, rigid grief models have been presented to understand the factors that influence grief, to classify grief in stages, to give grief specific characteristics, or to differentiated types of grief. However, some studies have criticized the rigidity of some stage models, although they recognized their contribution to inform specific bereavement reactions, researchers argue that models are rigid and linear minimizing the fluidity and duality of grief experience (Bonanno \& Kaltman, 2001; Stroebe et al., 2017; Worden, 1982; Wortman et al., 1993). 
Research shows that the dual-process model focus is an alternative to the rigidity of other models. It is based on the uncertainty of grief, recognizing that grief is not staged (Stroebe and Schut, 2010). The dual-process model, developed by Stroebe and Schut (2010), explains the ambiguity that exists in grief; that instead of the bereaved be centred on loss; it recognizes a dual process of grief and losses. This process appreciates that grief is multidimensional, recognizing a dualism in the way the bereaved reacts to grief. The process recognizes the oscillation between coping behaviour and avoidance, and the importance of the need of the bereaved to express and control feelings. However, this duality may be both beneficial and detrimental, depending on the circumstances (Stroebe and Schut, 2010; Stroebe et al., 2016; Stroebe et al., 2017; Stroebe et al., 2002).

A connection exists between the dual model of grief due to bereavement and the one due to homesickness. Leaving the place that is known as home is a universal loss recognize and experience in all cultures and societies. This phenomenon is connected to migratory grief because of both present dualities in their grief process. Immigrants faced the ambivalence of grieving their losses due to migration while trying to acculturate in a new country. (Stroebe et al., 2016)

\section{Migration Grief Perspectives}

Research studies argue that migratory grief is the response invoked by losses due to migration that impact the well-being of immigrants (Casado et al., 2010; Stroebe, \& Blink, 2008). In this project, the focus will be on grief caused by migration.

Migratory grief is a natural reaction to those losses; however, if it is not addressed without the proper support and services. Migratory grief can have severe effects on the well-being of the immigrants (Casado et al., 2010; De la Revilla et al., 2010). The literature argues that migration causes such a significant change in the structure of the life of immigrants that it results in periods 
of pain, frustration and disorganization and transformation (Grinberg and Grinberg,1989: De la Revilla et al., 2010; Ortiz, 2017).

In many of the studies reviewed, migratory grief is associated with the experience of migration (Achotegui, 2019; Bhuyan et al., 2016; Bucher-Maluschke et al., 2017; Casado et al., 2010; De la Revilla et al., 2010; De Snyder, 1987; Diaz et al., 2015; Gil, \& Vega, 1996; Horton, 2009; Moya et al., 2016; Perez, \& Arnold-Berkovits, 2018). Three of those studies focus on migratory grief and their effects in different immigrant groups; one study measured migratory grief and losses of Chinese immigrants in the United States (Casado et al., 2010). Another study focuses on the grief and losses of Moroccan immigrant women and their effects on their identity and wellbeing. (Ayala \& Dalouh, 2014). Finally, the last study article studies the effects of migratory grief on Latinos in Spain (De la Revilla et al., 2010).

Some studies have used quantitative approaches to develop methods to measure migratory grief (Casado et al., 2010). Other authors have developed frameworks to understand migratory losses (Perez \& Arnold-Berkovits,2018). Further mixed methods research has been developed to test migratory grief theory like the Ulysses syndrome among Latino immigrants (Moya et al., 2016; Achotegui, 2019). There has not been a study focusing on the migratory grief experiences of Latinos in Canada. Nevertheless, one research study found that focuses on Latino children's experiences with family separation due to migration (Vega, 2011).

\section{Migratory Grief \& Latinos}

Regardless of migration reasons, gender and country of origin, the immigration process brings unique challenges to the Latin American population. Most of the research focuses on the implications of the migratory process on the Latino community in the United States (Ayón et al., 2017; De Snyder, 1987; Gil, \& Vega, 1996; Horton, 2009; Moya et al., 2016; Perez \& Arnold- 
Berkovits, 2018). Some studies regarding Latinos experiences with migratory grief were developed by Latinos for Latinos and are available in Spanish with an abstract version in English. Due to the lack of studies available in English, three studies in Spanish inform this research (De la Revilla et al., 2010; Diaz et al., 2015; Gil, \& Vega, 1996; Moya et al., 2016).

The literature demonstrates that migration results in confront two types of losses when Latinos migrate; the fist one refers to physical losses, and the second refers to symbolic losses. Many factors influence those types of losses; race, gender, education, ability, socio-economic status (Ayala \& Dalouh, 2014; Casado et al., 2010; Casado \& Leung, 2001; Diaz et al., 2015; Gonzalez, 2005; Moya et al., 2016; Perez \& Arnold-Berkovits, 2018).

Grief and loss bring a vulnerability to immigrants and duality to their grief process that dictates their bereavement. During migration, immigrants experience multiple symbolic losses, and their bereavement is influenced by their unique cultural values (Stroebe and Schut, 1995;1996). Those cultural values influence immigrants' occurrences with grief, dictating their experiences with cultural bereavement. Eisenbruch (1984) states that it is false to assume that immigrants grieve in conformity with the customs established by the host society. Their cultural values and traditions dictate their bereavement process. Immigrants feel powerless by the loss of those traditions and values. Many circumstances can hinder the abilities of immigrants to continue to carry on with their values and traditions in the host country, affecting their cultural bereavement. (Eisenbruch, 1991).

\section{Cultural Bereavement}

Cultural Bereavement is the psychological response of a person to the loss of social structures, culture, language family ties, values and customs (Bhugra \& Becker, 2005; Eisenbruch, 1990:1991;). Social, cultural and economic factors influenced the bereavement expression of a 
person, factors as immigration, linguistic barriers, religious beliefs and financial issues have an immense impact on their grieving process (Bhugra \& Becker,2005).

Cultural bereavement in immigration studies focuses not only on the trauma of the losses due to migration but on the social strategies that immigrants used to overcome it. The process of acculturation may influence the cultural bereavement of immigrants (Bhugra \& Becker, 2005).

Eisenbruch (1991) concluded that if the migration system of the host country puts less pressure on immigrants to renounce to their cultural values and traditions, their migratory grief journey is less painful and complicated. The more access immigrants have to their traditions, and cultural values in their host country, the less complicated their grief process will be (Bhugra \& Becker, 2005, p.74).

Grief is universal; however, the mourning that influences bereavement varies significantly by culture and ethnic group. Bereavement in every cultural group is influenced by the values and customs of that group; those traditions can be so particular that they are not always known or understood by people outside the cultural group (Schoulte, 2011). In North America, grief and bereavement have been primarily studied among the dominant European American population, relegating experiences of minorities. North America has ignored that bereavement varies across cultures and ethnicities accordingly to their values. In this instance, for Latinos, their cultural values affect how they perceive the world, their interactions with others, influencing their bereavement experiences with grief and loss (Schoulte 2011; Vazquez \& Dinelia, 2011).

\section{Cultural Bereavement and Latino Cultural Values}

In Latin America, since colonial times, has existed a socially constructed structure of beliefs and traditions that dictated norms of conduct according to gender and are based in patriarchal ideologies (Smith, 1966). The cultural values and traditions of the Latin American 
population are a learned system of behaviours, attitudes and beliefs that are frequently carried through generations.

Even though Latinos represent a heterogeneous group, they share distinct cultural values, attitudes beliefs that make them more alike than different. Those shared values dictate the attitudes and behaviours of Latinos (Zea et al., 1994). Some of the most important values in Latinos are; marianismo, familismo and simpatica. Those values impact their experiences with migration, grief and bereavement. The cultural values of Latinos are incorporated in their bereavement process. Some of those values can influence healthy positive coping mechanisms, while others may hinder the grieving process (Diaz et al., 2015; Perez \& Arnold-Berkovist, 2018; Schoulte, 2011; Smith, 1966;).

Shapiro (1995) argue that structures of oppression such as poverty, racism, sexism, violence may influence the cultural bereavement and migratory grief of Latinos (as cited in Schoulte, 2011). In particular, for Latinas, the intersection of those oppressive factors and their cultural values not only determine their stories as immigrants but dictate their experience with migratory grief. Also, those migratory experiences can challenge the coping resources of Latinas who are already struggling through their adaptation to a new country while learning to live with their grief (Schoulte 2011; Vazquez \& Dinelia, 2011).

The unique cultural values of Latinas dictate their gender roles and experiences of bereavement during migration. Familismo value (closeness to their family) influences their cultural bereavement causing a conflict with their psychological attachment to their homeland and affecting their acculturation process in their host country (Perez \& Arnold- Berkovist, 2018).

Family ties for Latinas are essential to their social relations (Horton, 2009), those relations create a sense of belonging that identifies them with their culture, those ties to their home country 
extend deeply towards their culture and traditions. The values and traditions of Latinas are firmly attached to their culture, the losses of their language, traditions, social support, culture, even their ethnic food dictate their experiences with migratory grief and cultural bereavement. (De Snyder, 1987; Furman et al., 2009).

In Latin America, being simpatico is a quality that is very much appreciated in society and is a reflection of class, education and good manners. In the case of Latinas, simpatica dictates that Latinas must be caring, agreeable and forgiving. Those qualities are highly valued in the Latino community. However, the value of simpatica can also be deterrent to Latinas, influencing their migratory experiences to disguise discomfort. Forcing them into subordination and agreeableness even at the risk of trauma or violence. (Harper 2017).

Marianismo is a cultural belief that influences the behaviour of selflessness and selfsacrifice in Latinas. This cultural value is rooted in patriarchal ideologies impose by European Catholic settlers. It refers to the Catholic devotion of "Maria" the Virgen Mary. In marianismo, like the Virgin Mary, Latina women are honoured as mothers and nurturers who are "all-forgiving, sacrificing, morally superior and more spiritually evolved" (Stevens, 1973, p.62). However, marianismo limits Latinas identity into three roles: virgin (morally pure) mother (pillar of the family \& source of strength) or unconditional wife (compliance to men to maintain harmony). It demands Latinas to be submissive, religious, modest and pure. This value shaped and influenced the role of Latinas as immigrants (Gil \& Vazquez, 1997; Nuñez et al., 2016)

\section{Challenges of migratory grief In Latinos}

In one study, Latino experiences and challenges before and after their migration, intersect with the change of their social support network, and with their environment influencing their experiences with migratory grief (Diaz et al., 2015). One study examined specifically the pull 
factors associated with voluntary migration vs the push factors associated with forced migration. These factors contribute to migration dictate the experiences of Latinos with grief and bereavement (Perez, \& Arnold-Berkovits, 2018).Three research studies highlighted in their findings a correlation between migratory grief in Latinos and their process of acculturation and adaptation to their host country (Ayón et al., 2017; De Snyder, 1987; Gil, \& Vega, 1996)

Casado et al. (2010) argue that despise grief being a natural reaction to those losses. Migratory grief can have severe effects on the well-being of immigrants if it is not adequately addressed (p.612). The many research studies concluded that migratory grief affects their physical, social and psychological well-being of Latinos (Ayón et al., 2017; De la Revilla et al., 2010; Diaz et al., 2015; Moya et al., 2016; Perez \& Arnold-Berkovits, 2018)

Some studies highlighted the stress on Latinos influenced by familial, economic, social changes, family separation and cumulative losses (Ayón et al., 2017; De la Revilla et al., 2010; Perez \& Arnold-Berkovits, 2018). Other studies have examined more deeply the process of acculturation and its impact on the migratory grief of Latinos (Gil \& Vega, 1996; Perez \& ArnoldBerkovits, 2018). Acculturation is described in the literature as a process where the minority group adopts the cultural traits of the dominant group in public life while keeping its own culture in the private sphere (Perruchoud \&Redpath-Cross, 2011; Perez \& Arnold-Berkovits, 2018). However, research does not present a more profound analysis and reflection on how the identity of Latinos is shaped by migratory grief and cultural bereavement.

Regarding migratory grief effects on Latinas, one study concluded that with Latinas are even more vulnerable to challenges, due to their unique cultural values and the traditional expectations of the role of women in Latin America (Bhuyan et al., 2016). Other studies argue that the immigration process in Latinas may isolate them even further from the dominant cultures than 
males. Moreover, those changes without adequate support can affect their process of adaptation causing psychological effects in their well-being that will last throughout their life (Bhuyan et al., 2016; De Snyder, 1987; Horton, 2009;).

When Latinas immigrate, they have to pick up the pieces of their old life to be able to build a new one in their host country. That process, in many cases, comes with grieving the loss of their culture, family, language while facing frustration and disappointment due to the circumstances that they have to encounter in their host country (Perez \& Arnold-Berkovits, 2018). A variety of articles concluded that Latinas when confronted by losses and challenges during migration, they experience a sense of loss that can persist for decades or even a lifetime affecting their identity (Ayón et al., 2017; Horton, 2009; Perez \& Arnold-Berkovits 2018).

\section{Conclusion}

In conclusion, the articles found in this review relating to grief as part of migration were diverse. However, a varied range of research articles concentrates on measuring migratory grief, or in developing frameworks of models to understand migratory losses around the world. The review demonstrates that it exists a significant gap in what voices are being heard in academia in Canada. Research relating to Latino immigrants, in general, is scarce in Canada. Moreover, Perez \& Berkovits (2018), states that in North America, the phenomenology of "migratory grief, cultural bereavement and its effects in the identity and well-being of Latinas, is understudied" (p.91). No study was found that focuses exclusively on Latinas' experiences of migratory grief and its effect in Canada.

To expand my research into migratory grief in Latin American immigrants, I had to include research studies created in Spain and in the United States that focus on Latinos' experiences with migratory grief to enrich this literature review. Nevertheless, examining such a varied range 
of articles and research relating to the themes of my research topic helped me realize that there is not much available relating to my chosen topic of interest. Although Latin American experiences with migratory grief were included in the studies of this literature review, there is a gap in the literature about migratory experiences of Latino immigrants in Canada. An attempt was made to include studies relevant to the Canadian context; however, in Canada, there has been little research studying immigration challenges on Latinos Research studies exploring the grief process as its relation to Latino immigrants is almost non-existent in Social Work in Canada. Due to the lack of Canadian studies regarding migratory grief in Latinos, this review mostly focuses on the voices of Latinos residing in the United States.

However, in the review of the literature, a couple of studies were found that relate to the subject. One study was found that focused on the migratory experiences of Latin American children; this research did not address their migratory grief. However, it focuses on Latino children's experience of loss regarding family and cultural values (Vega, 2011). Another study written by Gastaldo (2014) argues that for many newcomers in Canada, their process of migration is determinate by the losses (economic, social, cultural and personal) and the bereavement suffered during their immigration journey (p.62). The study focused in immigrants in general without any particular lens to a specific ethnicity and its connection with cultural values. The other study that was found was center in Latinas immigrants, but the focus was in Latinas immigrants fleeing violence; without addressing precisely issues of migratory grief, that dictates their experiences (Bhuyan et al., 2016).

This review informs my research question of "how do migratory grief and cultural bereavement impact the identity and well being of Latinas immigrants in Canada?”. In general, all the studies in this review aimed to bring attention in one way or another to the impact of 
migratory grief in the lives of immigrants. Furthermore, this literature review shows that there is an influence of Latin American cultural values on the migratory grief journey of Latinas. Finally, this review demonstrates that in North America in general and in Canada specifically, the phenomenology of migratory grief, cultural bereavement and its effects in the identity and wellbeing of Latinas, is understudied.

This review reveals that research in Social Work in Canada relating to Latino/Latina immigrants, in general, is scarce. In a variety of the studies presented in this literature review, the experiences of Latinos are seen through the idiosyncratic lens of the researcher interpretation dictating how the experiences of Latinos are being portrayed in research. This anti-oppressive project aims to challenge these notions through the use of critical race theory as a framework. Through the lens of Latino critical race, the experience of Latinas will be analyzed to fully understand and validate Latinas bereavement experiences of migratory grief, considering their social, cultural and migratory factors that influence their immigration process. 


\title{
CHAPTER 3
}

\section{THEORETICAL APPROACH}

\author{
So, \\ here you are \\ too foreign for home \\ too foreign for here. \\ never enough for both. \\ - “Diaspora Blues” by Ijeoma Umebinyuo, (goodreads, n.d.)
}

\section{Critical Race \& Latino Critical Race Theory}

\section{Introduction}

In the book Critical Race Theory: The Cutting Edge, Delgado and Stefancic (2013) state that "our social world, with its rules, practices, and assignments of prestige and power, is not fixed; rather, we construct with its words, stories and silence. Nevertheless, we need not acquiesce in arrangements that are unfair and one-sided. By writing and speaking against them, we may hope to contribute to a better, fairer world" (p.13). This project aims to challenge the imbalance of power and notions of invisibility in the migratory grief journey of Latinas immigrants in Canada by using Latino critical race theory as a framework.

Critical Race Theory (CRT) and Latino Critical Race Theory (LatCrit) are the theoretical foundations for this research study. CRT will be used to centers race at the front of issues affecting racialized minorities. Moreover, LatCrit theory will be used to takes some steps further, and it will analyze the migratory experiences of Latinas and their intersection with their social location, in order to understand their lived realities of cultural bereavement as immigrants in Canada

Latino critical race theory (LatCrit) will be applied to names, questions, challenges, and calls out structures of oppression and their systems created by the dominant culture to marginalize Latinos by recognizing that racism is embedded into the daily practices of those structures (Perez 
Huber, 2010). Thus, CRT and LatCrit theory disputes confronting practices that enable imbalance of power to persist while also challenging these practices to seek liberation from systemic oppression. (Delgado et al., 2017; Solórzano \& Delgado 2001;)

\section{Critical Race Theory}

Critical Race theory deconstructs issues of race, power, and oppression by acknowledging that racism is necessary to recognize it to be able to challenge it. CRT research begins with the perception that minorities have multiple strengths, capitals and skills that are often placed under a devalued lens. Moreover, racialized minorities are denied access to resources due to the domination of systems of whiteness (Delgado et al., 2017).

Crenshaw (1995) argues that critical race analysis reveals policies perpetuating racism, sexism and subordination of minorities. Another study argues that oppressive policies have been created to advance the agenda of the white elite. Therefore, it is imperative to challenge those views by critically examining those structures of oppression within a historical and cultural lens to deconstruct racialized content and thinking (Bernal, 2002).

Critical Race theory has had much influence in research that became an international movement. Aylward (1999) argues that in Canada, the Critical race theory movement started in 1980. Canadian theorists of colour started to follow the work of American critical race theorists by incorporating in their analysis the role of race and racism in political, legal systems. Although the image of Canada to the world is tolerance, exists a racial inequality. A dichotomy between "the public image of Canada as an "egalitarian" society free from the racism that plagues the United States and the actual racial reality in this country" (Aylward, 1999, p.40) 
The exclusion of people of colour had contributed to an underrepresentation of not only research about minorities issues but also of the exclusion in academia of researchers of colour, which in turn has contributed to slower development of Critical Race Theory in Canada" (Aylward, 1999).

Fernando \& Rinaldi (2017) argue that critical race theory in Canada regarding immigration is exclusionary based on race. Immigrants of colour are excluded and alienated based on the intersection of their social location and imbalances of power. The use of Critical Race theory on issues that racialized immigrants faced when immigrating to Canada can aim to challenge immigration policies and practices that hinder the integration of immigrants into society.

From the theoretical framework of critical race theory, Latino critical race theory was formed to question and dispute dominant ideas of devaluation such as colorblindness and meritocracy. LatCrit shows how those ideas operate to disadvantage Latinos and to further the advantage of the dominant white group (Bernal, 2002; Delgado \& Stefancic, 1998).

LatCrit is rooted in critical race theory; however, it deepens its focus, interrogating how approaches to race and civil rights ignore the problems and special situations of Latinos, including bilingualism, sexism, immigration reform. Furthermore, LatCrit confronts those dominant ideas of whiteness and colonialism put in practice to serve the dominant society, making visible Latinos experiences. (Delgado \& Stefancic, 1994;1998; Stefancic 1997; Bernal, 2002).

\section{Latino Critical Race (LatCrit)}

Latino critical scholarship has existed for a long time; however, it has been largely ignored by white academia. It originated when the scholar Acuna (1972) reformulated American history by taking into consideration the history of the United States colonialization on Mexican land. Acuna (1972) "focused on the colonization effect on Mexicans living in the colonized territories 
of California, Nevada, Utah, Nuevo México, Texas, Colorado and parts of de Arizona, Wyoming, Kansas y Oklahoma” (as cited in Delgado \& Stefancic, 1998).

The thesis of Acuna (1972) expanded to include all people immigrating from Spanishspeaking countries in the North American continent, forcing scholars into the examination of North American society from a Latino perspective. The analysis by Acuna (1972) formed a more profound understanding of how the dynamics of race, gender and power intersect with the cultural values, beliefs, language, spirituality of Latinos. (Delgado \& Stefancic, 1998).

LatCrit, through the lens of migration, goes deeper in examining how issues of race, culture, gender and power intersect with the migratory grief process of Latin Americans. Furthermore, LatCrit, in this research project, aims to challenge preconceived notions of how Latinas assimilate their losses in a new country. To critical analyze under the lens of LatCrit, Latinas participants in this study will be invited to share their stories of grief and migration through poesy, to challenge established ways of doing research. This approach will give value to the participants' poetic expressions by recognizing the influences of their experiences in the research process (Yosso, 2005).

LatCrit not only brings to light issues of oppression but also goes one step further by bringing awareness of the problems of racial subordination that exist toward the Latin American population. LatCrit analysis explores how Latina women as a group are particularly oppressed and relegated in issues of migration bringing a new perspective of how the dominant group marginalized Latinas by focusing in their deficits instead of focusing in their skill and ability to resist and persevere (Grillo, 1995; Olmos, 2019; Yosso, 2005)

\section{The Basic Tenets of Latino Critical Race Theory}

\section{Race is socially constructed}


One of the tenants of CRT \& LatCrit is the principle that race is a socially constructed phenomenon. There is no biological basis for racial categories. However, minorities are subjugated to stereotypes and biases based on the perception of the dominant group of their ethnicity. Latino/a critical race (LatCrit) theory deconstructs issues of race by addressing classism, racism and sexism that subordinate Latinos experience on their immigration status, sexuality, culture, language and migratory grief (Johnson, 1998; Montoya, 1994; Stefancic, 1997; Yosso, 2005).

The social construction of race is central to how people of colour are constrained in society. Latino/a Critical Race deconstruct the identity of Latinos and analyze how they experience the world based not only on their racial identifications but also based on their gender, class, ability. Through storytelling, Latinos can voice their experiences and regain their power by narrating stories of resistance (Yosso, 2005).

\section{Storytelling/counter storytelling}

Latino culture incorporates a long, rich tradition of storytelling. Though the narration of their stories and counter-stories, Latinos reclaim their power and reconnect with their culture and values. This tenet identifies the oppression of Latinos, exposing imbalances on power relationships by recognizing that knowledge is socially constructed and political (Delgado et al., 2013) In this project, ideas of who construct knowledge are defied by inviting Latinas to cofacilitate research by narrating their experiences with migratory grief as LatCrit counter-story strategy to reclaiming their power (Delgado et al., 2017).

Latinas will be invited to reclaim their power by telling their unique stories through poesy of leaving their home country, migratory grief, cultural bereavement and how they intersect with their identity and their settlement process. Those narratives can provide valuable information to 
Canadian-Latin American studies, informing service and programs. Findings can guide scholars in understating factors that contribute to their acculturation in Canada (Stefancic, 1997).

When immigrants arrive in North America, they have to pick up the pieces of their old life to be able to build a new one in their host country. In many cases, that process comes with grieving the loss of their culture, family, language, while facing frustration and disappointment due to the circumstances that they faced during their settlement. Confronted by those losses and challenges, Latinos experience a sense of loss that can persist during their acculturation process (Perez \& Arnold-Berkovits,2018).

Understanding under the lens of LatCrit, the counter-stories of Latina women within migratory grief, cultural bereavement, and their influence in their identity and settlement process will provide valuable information to Social Work and service providers to create a practice that addresses those issues. (Delgado et al., 2017).

\section{Each voice of colour is unique}

The final tenet use in this theoretical perspective relates to the preconceived notion that exists a unique voice of colour. This tenet aims to disrupt notions of essentialism; they believe that there is a unique experience for everyone in a group (Grillo, 1995). CRT and LatCrit refute that notion under that there is only one unique voice of colour. Although race can never be subtracted from one's identity, the intersections of class and gender, help to create a different experience for the individual. It should be" up to that minority to communicate to the white dominant counterparts matters that the whites are unlikely to know" (Delgado et al., 2017, p.11).

Under the LatCrit lens notions that "each voice of colour is unique," theorists believe that due to the Latin American population has had different histories and experiences with colonialism, oppression and subordination, those issues of oppression have been ignored or relegated by the 
white state. (Grillo, 1995) Latinos are the most qualified to communicate the issues affecting them instead of their white counterpart speaking for them. (Olmos, 2019). As a group, Latinas have multiple voices and experiences that deserve to be put on the front and be heard by academia and therefore, they should not be grouped into predetermined categories based on stereotypes, racism and bias

This study aims to inform research and academia of the need to challenge colorblind notions that dominate migration policies and services in Canada. Furthermore, it aims to promote "unique voices of "colour, in this case, Latina voices. The participants will narrate their unique stories of migratory grief, their challenges, their resistance and the effects of grief on their well being and how they intersect with the racialized power and inequalities that construct the migratory process in Canada.

\section{Latinas stories under Latino Critical Race lens}

LatCrit can be used to reveal the ways Latinas experience race, class, gender, and sexuality, while also acknowledging their experiences with issues of immigration status, language, ethnicity and culture. Thus, LatCrit enables researchers to better articulate the experiences of Latinas, specifically through a more focused examination of the unique forms of oppression this group encounters (Solorzano \& Bernal, 2001).

A LatCrit theoretical framework in this study considers the intersectionality of race and gender with other issues such as immigration status, class, language, socio-economic status, that Latinas negotiate daily. LatCrit theory will guide these research findings to have a better understanding of how issues such as immigration, migratory grief, cultural bereavement intersect with Latinas identities. (Pérez Huber, 2010, p. 79) 
In migration, CRT centers in ways race, class, gender, sexuality and other forms of oppression manifest in their migratory experience (Perez Huber, 2010; Yosso, 2005; 2006). Latino Critical Race Theory emerges as an extension of the efforts of CRT in research. Although in Canada, there is no literature based on the Canadian experience of Latinas immigrants. LatCrit applied to Latinos immigrants goes one step further from CRT by questioning forms of marginalization that dictate the stories of Latinas in North America confronting dominant ideologies of oppression such as whiteness, sexism, patriarchism (Solorzano \& Bernal, 2001). Furthermore, LatCrit challenges systemic oppressions by bringing into consideration the unique characteristics and cultural values that influence the identity of Latinas (Yosso, 2006).

Haig-Brown (2012) argues that our problems come not only from our lack of willingness to listen to each other but also from our avoidance of sharing our stories of colonialization (p.88). Through the use of poetry, LatCrit can aid in decolonizing autobiographies to deepen the discussion of gender and race in a way that will expand our understanding of Latinas' experiences. Latin Critical Race perspectives can aid Latinas in understanding their expediencies with the feeling of not being "good enough" or being the "other" created by the colonial state in Canada. (Murcina, 2019)

\section{Conclusion}

The Latino Critical Race Theory framework will guide this research to connect the findings of this study with the research question presented. The LatCrit framework is supported by a qualitative inquiry of a narrative and art-based poetic expressions to present the voices of Latinas immigrants sharing their stories of grief and bereavement due to migration. This research continues to challenge the notion of the invisibility of migratory grief by creating a space where poetic narratives are used to validate the experiences of loss and grief in Latinas. 


\section{CHAPTER 4}

\section{METHODOLOGY}

To understand me, you have to go

through what I've gone through...

Hunger doesn't recognize borders

Nor race, nor color.

I've encountered it and I've never forgotten.

My traveler's shoes.

My carpenter's heart.

All that I have that is strong and pure,

Is indissoluble and emigrant

- "Traveler's Shoes" by Dolores (Christoph, 2014)

\section{Introduction}

As the Immigrants diaspora communities increase in Canada, so it does the need to understand and research the invisibility of grief and its impact on immigrants. Latin Americans can assist social work research in Canada by sharing their migration stories to gain a better understanding of the issues and challenges of the Latino diaspora.

The study explores the experiences of grief and loss of Latina women due to migration. A qualitative approach was chosen in order to gather a comprehensive, in-depth understanding of the unique experiences of these individuals. This research project uses as a base, a postmodern artbased approach to address migratory grief.

The methodology of this project uses poetry as inquiry and as a method through a design of narrative and art-based approaches. Through poetry inquiry, Latinas will create and rediscover their knowledge. Poetry is a powerful tool to use to tell stories that we need to advocate for social justice (Leavy, 2018) This research disrupted bias notions of how Latinas have been represented and treated in Canada by using a narrative and poetic inquiry as a methodology. 


\section{Qualitative Research}

As it was mentioned earlier, throughout an anti-oppressive perspective, this project uses narrative and poetic inquiry as a methodology. The theoretical framework of Latino critical race theory is center into the testimonies of Latinas immigrants to answerer the question of this study regarding the effects of migratory grief and cultural bereavement on their well being.

Qualitative research understands that human realities are subjective instead of rigid and that individuals have a unique interpretation of reality based on their perspectives. Qualitative approaches believe that the researcher enriches the study by participating "developing a better understanding of how the world is constructed" (Perry, 2010).

Qualitative research allows the researcher to use "reflexive elements that enable the participant-researcher relationship to discover substantive meaning” (Erlingsson \& Brysiewicz, 2013). According to Gillian (1982), it is essential as researchers to create spaces for women to find their voice and to regain their power. Furthermore, Gillian (1982) argues that it is vital to create research that deviates from the dominant male perspectives (Gilligan, Spencer, Weinberg, \& Bertsch, 2003; Zambo \& Zambo, 2013). This research uses a qualitative design that allows for the participants to express their perspectives in their own words using poetry. Qualitative researchers believe that researcher participation enriches the study

The question of this research challenges traditional research models. It demands a holistic and qualitative approach, that deals with the idiosyncratic experiences of participants and assumes that there is not a universal truth or realities, but rather many truths and realities to be found (Perry, 2010). Those realities are bound by the context of the stories of migration of each participant. A qualitative design in this research brings to light issues of migratory grief and cultural 
bereavement, as well as the influencing factors that hinder the process of acculturation of Latinas (Glaser, 2017; Solórzano \& Yosso, 2000).

\section{Narrative}

A narrative method is very helpful to research marginalized populations who might have complex power relations and to bring to the front issues of power relations. A narrative approach may bring to light issues that otherwise will stay dormant or ignored. (Clandinin, 2007).

In this research, a narrative design gives participants a voice to tell stories through poetry and interviews, revealing to the reader that others may have similar experiences. Through the collection method of storytelling, the narratives of three Latinas immigrants were collected through their poems and semi-structured interviews. This method is emphasized in critical race theory and in LatCrit describing that purpose of storytelling ( counter-narrative) "is to cast doubt on the validity or accepted premises or myths, especially ones held by the majority" regarding minorities (Delgado and Stefanic 2001,p. 144) .The use of storytelling in this study supported Latinas into sharing their experiences with migratory grief and cultural bereavement through their testimonies in their poems and interviews.

Dialogue and collaboration between the researcher and participants were established through a semi-structured interview method were their stories show that the social realities of minorities (Latinas) have been obscured in social work research (Leavy, 2018; Moffatt, 2019). Furthermore, narrative stories can name discrimination and inequalities, so once named them, they can be combated. (Moffatt et al., 2018; Moffatt, 2019) This method may begin a process of awareness by calling attention to neglected evidence, reminding readers of their shared humanity with the participants. (Delgado \& Stefancic, 2013) 
A narrative can help in bringing awareness of the process of the negotiation and renegotiation of the identity of the participants, challenging traditional and stereotyping representations of Latinas identities (Falkuner, 2006; Faulkner, 2009; Leavy, 2018). Moreover, findings in narrative approaches may contribute to the development of new theories, inform practices, truthfully reflect experiences and needs of marginalized populations, and in the collection and interpretation of data narrative methods can reframe the way that participants resonate with the research (Hyden, 1994; Fraser, 2004).

Using art-based and narrative approaches combined in research creates a space for a reflective practice that is open, considers emotions, allows for a creative presentation of social affairs through art, and "provides a catalyst for the process of critical reflection" (Moffatt, 2019, p.181).

\section{Postmodern Art-Based Approach to Grief}

This research is based on the postmodern concept of art-based approaches and its relevancy to reflection (Moffatt, 2019). Through this postmodern approach, this study incorporates narrative and art-based poetry to challenge dominant discourses of what constitutes a legitimate narrative based on rigid linear concepts of how stories should be presented (Sands \& Nuccio, 1992).

Postmodernist approaches in social work reject linear, rigid narratives defying categories in order to embrace the temporary and the new. One can move to a holistic way of thinking by deconstructing established ideologies (Moffatt, 2019). Furthermore, postmodern social work pushes for a critical exploration of power and how it is exercised in practices and discourse. Discourse can offer an alternative to understanding human needs by offering space through artbased approaches. The new arts-based expressions create and co-create new forms of knowledge that lead to the possibility of new social relations (Moffatt, 2019, p.44). 
Regarding art-based approaches, postmodernism rejects the idea of artistic development as goal-oriented, or the notion that only men are artistic geniuses, and the colonialist assumption that non-white races are inferior. This rejection opened the space to new ideas and creations in art; those expressions of art have been challenging established ways of thinking, bringing new art perspectives that can inform social work practices (Buskirk 2003).

From a postmodern approach, Foote \& Frank (1999) argue that "grief is undisciplined, risky, and society seeks to discipline grief as part of its surveillance" (as cited in Walter \& McCoyd, 2016, p.170). The areas of grief and loss in postmodern social work reject those ideas by understanding grief unconventional behaviours reinforcing a new way of perceiving, feel and express grief.

Postmodern social work in grief support, through reflective practice and research, is always conditional on historical and social context, embracing principles of multiples ways of knowing and truth by disrupting the traditional ways to grief (Foote \& Frank, 1991; Walter, 2007; Moffatt, 2019). Moreover, postmodern social work in grief introduced art-based approaches as a way to deconstruct and reconstruct knowledge challenging the idea that there was one inherent meaning to study, research and express grief (Walter, 2007).

\section{Feminist Postmodern art-based approach to Grief}

Feminist in postmodernism in social work takes a step further; it considering the diverse nature of the population, objecting to binary categories by emphasizing diversity, multiplicity, and pluralism. In narrative approaches, postmodern feminism argues that stories are nonlinear, and reject "legitimatization" of narratives based on rigid notions of what is considered a valid narrative. (Fraser \& Nicholson, 1990) Furthermore, postmodern feminism desire to change the social and 
political order so that women will be able to tell their stories of marginalization as a way to empower themselves and fight systems that oppressed them. (Sands \&Nuccio, 1992, 492).

The purpose of using poetry as a tool to narrate the migratory grief experiences of Latinas is to generate new information, and to allows the participants to reclaim their stories by giving them space for their voices to be heard. Furthermore, this research study not only aims to bring immigrant women experiences into the light but also to challenge pre-existing rigid concepts and stereotypes regarding grief, loss and bereavement and its intersection with migration.

\section{Poetry as an Art-based Method}

In the last decade, poetry in qualitative research has gained validity as an art-based approach. Incorporating art-based methods in research can be an accurate, precise, functional and valuable qualitative research strategy "for the reason that it allows the researcher to document lived experiences interestingly and artfully" (Zambo \& Zambo, 2013, p. 4). Arts-based practices are a useful tool in gathering and generating data due to the compelling depiction of how the reality of the individual is experienced. In social work research, art-based approaches have become a method for producing knowledge by understanding the social context of the participants' stories. These methods enable the creation of information by reflecting experiences that are emotionally driven (Clandinin, 2007).

In art-based qualitative research, poetry as a method of inquiry is a growing area of interest for researchers. The nature of participants' experience in research is often taken for granted. Poetry as a method of inquiry challenges misconceptions of being difficult and ambiguous by becoming a tool for social justice. (Leavy, 2018 p.209) Based on those notions, this research recognizes Latinas' resilience and capacities in facing adversity. Furthermore, the project critique and challenge preconceived colonial notions of representation, migration and grief by creating an 
empowering space that will enable the researcher to engage more consciously with the participants through their poetry. (Galvin \& Prendergast, 2016; Leavy, 2018; Moffatt, 2019).

Poetry can be seen as a "form of research, and way of knowing, it can be therapeutic for both the participants and the reader" (Wakeman, 2015, p.50). Through poetry, Latina women will rediscover their knowledge, disputing preconceived notions of how they have been represented and treated in Canada (Madison, 2005, p.4). Poetry has a significant impact on the understanding of grief on the bereaved and on determining what the grief experience encompasses in the researchers (Stroebe, 2018, p.68).

Poetry can be effectively be used as a research method to inquiry and as a tool of data through the lens of Latino critical race. This type of art- based method is incorporated in this research to bring the voices of the participants to the front (Galvin \& Prendergast, 2016; Zambo \& Zambo, 2013). The narrative and art-based poetry methods in this study make Latinas stories visible so their narratives will not only inform this research, but they will aspire to inform social work academia and practices.

\section{Design and Approach}

As mentioned previously, this anti-oppressive, qualitative research uses as a framework Latino Critical Race theory to inform this study. LatCrit is used to address gender, class, racial subordination and to engage with women of colour positively (Solórzano and Yosso, 2000). Establishing that immigrants' lives are not frequently recognized by academia, mainstream literature and the general public (Glaser, 2017)

Under the lens of Latino critical race theory, this study recognizes the knowledge of people of colour, confronting traditional research paradigms (Solórzano \& Yosso, 2000). This qualitative study, under the design of narrative and art-based, uses a narrative inquiry with an art-based poetry 
component as a design. It recognizes the value of the stories of Latinas by using poetry and interviews to inquiry and collect the experiences of participants with migratory grief (Bishop \& Willis, 2014).

Poetry and semi-structured interviews are used as an inquiry to gather information while acknowledging oral storytelling traditions in Latin Americans. Anzaldua (1990) argues that the use of an arts-based component in research supports the continuation of traditional methods of sharing by drawing on the lived experiences of women of colour (Glaser, 2017). Art-based research includes a variety of methodologies, the narrative is one of them, and it can incorporate many creative expressions, including poetry (Glaser, 2017; Knowles and Cole, 2008).

Poetry is an important tool of this research, it is rooted in postmodern social work, Latino critical race theory and feminism, and it is used as an art-based design, as a method to inquiry, collect data and also as a method of presentation and representation (Zambo \& Zambo, 2013). Poetry as a method of representation, captures the contextual and psychological worlds of both the participant and the subject, making visible participants experiences and putting voices of minorities to the front (Bishop \& Willis, 2014; Carr, 2003; Rapport, 2008). To be fairly represented, participants were given a choice to write their poems and tell their narratives in their native language, Spanish or in English. Finally, poetry as a tool of data in this study aims to create knowledge based on the narratives of the researched and researcher (Cahnmann, 2003; Langer \& Furman, 2004; Piirto, 2002; Zambo \& Zambo, 2013.)

Due to the COVID-19 outbreak, the approach of this research was modified to accommodate safety protocols to protect participants and researchers. To prevent any risk, this study follows the guidelines of Ryerson Research Ethics Board (REB). All personal contact and 
interviews between participants and the researcher were modified using social distance guidelines to prevent infection and to safeguard the well-being of participants and researchers.

\section{Recruitment}

In relation to recruitment, I combined purposive sampling and snowball as a recruitment strategy. I sought out participants through the support of a non-profit organization that offers emotional support through an anonymous phone line to citizens in the Region of Peel and the MSW program at Ryerson University. Those two organizations support this investigator by sending recruitment information to their contacts.

The first step of my recruitment strategy was to create a recruitment email in Spanish and English that fulfilled the Ryerson Research Ethics Board and COVID-19 guidelines. The recruitment email was to send out to the non-profit support services organization providing information on the study I am conducting. Through this, the coordinator of the Spanish services forwarded the email to other agencies that provide service to the Latin Community and the Latino listservs. The MSW program at Ryerson University forwarded the recruitment email to their MSW listservs. Also, potential participants might have passed on the recruitment information to others.

All methods of correspondence were switched to only email and phone. The recruitment stage was completely done through email due to COVID 19. Potential participants were invited to be in contact with me through email. The selection process involved responding to the interest of potential participants through email. All forms and documentation for participants were presented in Spanish and English. The participants were selected by identifying themselves according to the inclusion criteria outlined in the recruitment email. Participants were given the option to be interviewed and to create their poetry in Spanish or English. This study confronts traditional models of researching by putting Latinas voices to the front. It was up to the participants 
to decide in what language they felt more comfortable responding and sharing their experiences. (Zambo \& Zambo, 2013)

Once the participants selected themselves and confirmed their interest in joining the study, a protected link was sent to participants to read and fill the const form. Following COVID-19 guidelines, a Google form was created for consent, where participants indicated their consent by submitting the form digitally. The link to access the consent form was sent to participants by email before the first phone interview. Participants were able to access their consent form and printed it for their records.

\section{Criteria}

The criteria for potential participants required them to be more than 18-year-old, identify themselves as Latina women, that have immigrated from any country that forms part of Latin America and currently residing in Canada for at least a year.

Five potential participants showed interest in participating in this research; of those five, just three potential participants continued with the recruitment and interview process. An issue that I encountered is that two potential participants were not able to continue to the recruitment stage. One potential participant decided no to continue with the recruitment process because she felt that she was not ready to share her story with the world. The second potential participant was disqualified from continuing because she did not meet the residency requirement established in this research. The other three potential participants filled the recruitment criteria and decided to continue with the interview process.

\section{Interviewing}

This qualitative narrative and art-based study introduce narrative methods such as poetry as storytelling and oral testimony in the form of a semi-structured interview. Tenets of Latino 
critical race principle argues that knowledge gathered about Latinos have to stem from their lived experiences. (Clandinin, 2007; Glaser,2017; Solórzano and Yosso, 2000).

In research and academia, Latino critical race, Latina feminist, and Chicana theories use storytelling methods as the dominant form of creating and sharing knowledge and as a counteract measure against rigid methods of collecting knowledge (Delgado, et al., 2017; Solórzano and Yosso, 2000;). This research gathers information through poetry as a storytelling and a semistructured interview format that uses open-ended questions to allow the participants the opportunity to expand their comments regarding the themes found in the poems. The purpose of using this method is to create a decolonizing space that empowers Latinas to produce and share their knowledge as resistance to dominant ways of data collection.

As a researcher, I centre myself through this lens as well. I included in this study, a poem voicing my experiences with grief as a Latina immigrant with a narrative of my connection to this topic. I used my poem to center the poetry of the participants and as a form of resistance to Anglowestern ideologies of gathering data.

The interviewing process was done through phone calls due to the COVID-19 pandemic. Participants consented to be audio recorded during the interviews and to send their poetic expression through email. An option was given to participants to write a poetic expression narrating their stories of migration and loss if they did not feel comfortable creating a poem. All three participants created poetry to narrating their story of migratory grief and its impact in their life as Latinas.

Using Latino storytelling narrative methods in the form of poetry and semi-structured interviews in this study validate their experiential knowledge and contribution to this research. Therefore, in this study, participants were given the option to decide what language (Spanish or 
English) they felt more comfortable responding to and sharing their experiences (Solórzano and Yosso, 2000). Two participants create their poems in English and one participant in Spanish. Poems were translated at English and Spanish accordingly by the principal investigator to present findings. A copy of the translation of the poem was given to the participants for their records.

During the interview stage, I collected the poems from three Latinas immigrants who shared their grief experiences with me trough their poetic expressions, as well as orally under a semi-structured interview. Creswell (2013) argues that collecting stories using "this method assists in gather knowledge that is produced through the collaboration and dialogue between the researcher and the participant" (p.71).

Participants were required to have an initial and final interview of one hour long each one in two weeks. The first interview was done after participants filled their consent form electronically and were informed of their rights as participants. The purpose of the first interview was to serve as an orientation of the research study to clary any questions about their rights procedures, expectations, potential risks and benefits of participation and to give instructions to create a poem.

In the week between the first and the second interview, in their free time, at their leisure, participants were asked to invest two hours of their time and create a poem describing their experiences with migration and grief as Latina immigrants. In the second week, during the second interview, participants were asked to read their poems and to talk more in detail about their poems.

The conversations with the participants followed a semi-structured interview designed that intended that the dialogue was friendly and informal. This format encourages participants to share their insights, feelings and subjective meanings and to express themselves as they normally speak and think (Neuman 2011; Vega, 2011). An in-depth interview with semi- unstructured questions 
was designed to allow the participant to guide the conversation; the questions were reworded spontaneously to fit the context of the participants' poetry.

Due to the personal nature of sharing experiences of loss and grief, a mindfulness exercise, emotional support and referral services were available during the interview process. As a final step of their second interview, participants were invited to do a grounding exercise to recognize and validate their emotions. The goal of the exercise was to help participants to release memories that were brought back with the poem and interview process. This mindfulness therapy has been proved in grief support to ground participants.

\section{Data Analysis}

After the semi-structured interviews, the data collected through the poetry and narratives of the participants were transcribed. A thematic analysis was used to find themes within the narratives shared by the participants in their poetry and stories. (Bold, 2012; Calero,2017). The data collected in the poetry and interviews were examined "for commonalities and differences that exist among and between participants' stories" (Fraser, 2004 p.194). Furthermore, Fraser (2004) argues that in narrative research, to be able to examine personal stories is necessary to present an "analysis that is coherent and corresponds not only to those stories but to the objectives of the research as well"' (p.196).

The themes finding in the poetry was cross-referenced with the themes found in the interviews. Similar themes were found in the poems and interviews of the participants. Direct quotations from the poetry and interview transcripts that represented the themes, were used in the analysis to give a space where the voices of the participants are heard. Being a Latina immigrant has given me a unique perspective of certain events and occurrences in the narrative of the 
participants, influencing my understanding and analysis. Narrative researchers argue that researchers that are insiders gain an understanding that others who have not experienced that issue would. Furthermore, minority researchers have value in research regarding minority groups because researchers that belong to a minority can provide a distinct perspective of the issue studied due to be an insider. (Dei, 2000; Lau, 2008; Ng, 1995; Young, 2004 ) Minority researchers provided a unique perspective of the data analysis by "questioning information provided by the participants" (Solomon et al., 2005, p. 152). The themes that resulted from the analysis are presented and organized in the findings.

\section{Conclusion}

In postmodern social work and qualitative arts-based approaches, poetry and narratives are valuable tools for presenting complex lived experiences (Moffatt, 2019). Using poetry as an artbased method of inquiry and data in this study will help in bringing to the front the narratives of cultural bereavement and grief of Latinas immigrants. The research is designed by incorporating arts-based and narrative inquiry to help understand how cultural practices of Latinas immigrants related to their migratory grief process by describing and analyzing their personal experiences through poetry. Incorporating poetic and narrative inquiry in this research has the finality to create a safe space for Latina women to express and share their stories of grief and migration through their artistic, poetic expressions. Combining poetic inquiry with narrative approaches aims to validate the knowledge of 'ordinary' people, especially women, in this case, Latina women who are often omitted in research and academia in Canada (Fraser, 2004, p. 184). In the following chapter, the findings of the study are presented and organized according to themes that resulted from the analysis 


\title{
CHAPTER 5
}

\section{FINDINGS}

\author{
All I want is a better opportunity, \\ money and for my kids a community. \\ Lock them up in cages, the orange man demands! \\ While my people clean his hands. No! \\ Don't tell me I don't deserve to be in the land of the free \\ I will clean your house and he will cut your yard, \\ because people like us could never get degrees. \\ I am not like you, I actually worked hard. \\ - "I am not like you"- Victoria (Christoph, 2014)
}

\section{Losses became Gains}

In qualitative research, the researcher must be aware of her own bias, values and interests. It decreases the possibility that they will be projected into the participants (Josselson, Lieblich, $\&$ McAdams 2003, Glaser, 2017) As a researcher I am aware of the subjectivity and context of my experiences as a Latina immigrant and how they intersect with the research project. In the following section, I present in this chapter a poem that I wrote as a critical self-reflection of my experiences with migratory grief as a Latina immigrant in Canada and an analysis of the impact of migratory grief in my settlement journey. The participants and their poems are presented next. Finally, the main themes found in the poems and stories of the participants will be presented.

\section{My poem}

\section{$\underline{\text { Losses became Gains }}$}

I was part of the invisibility of grief.

I mourned the losses of leaving my country, but nobody acknowledged it, I was left on my own, without resources or support

To settle on, with the pressure to move on

Nobody cared about my grief 
Wasn't this something that I wanted?

Then don't complain, don't share your losses

My grief became part of me,

I have had to equilibrate my identity to preserve it

When society wanted to erase it

My identity was forever changed,

my losses became my gains...

I left Mexico with the idea one day to come back,

But I discovered the powerful grip that Canada had

I without realizing it, I fell in love with Canada's idealism for social justice and acceptance.

That is why I became a social worker to offer grief support,

to those that are lost,

and to create a consciousness

of immigrant issues that need our awareness.

My identity was forever changed,

my losses became my gains...

Once I was grieving the loss of language, sooner I discovered the healing power, that speaking Spanish has for a social worker, helping immigrants and newcomers.

How offering support in their language, opens the path to integration and acceptance.

My identity was forever changed,

my losses became my gains...

I am not the same person that I was when I came,

My identity has been forever changed...

Overcoming obstacles associated with migration,

Has brought awareness into my profession.

It has been expanded like the palette of colours of a painter,

Discovering colours unknown, with brighter tones

Those experiences had increasing my awareness, of the circumstances faced by clients.

My identity was forever changed, my losses became my gains...

Written by: Covadonga Blanco 


\section{Analysis}

I was part of the invisibility of grief.

I mourned the losses of leaving my country, but nobody acknowledged it,

I was left on my own, without resources or support

To settle on, with the pressure to move on

When I immigrated to Canada, I was characterized as an outsider; as an immigrant, I was given a label based on my ethnicity. I was not a regular woman part of society anymore. I had to be categorized and levelled as Latina or Hispanic, so the host society could fit me in their preconceived categories to permanently other me as a foreign. I experienced, for the first time, what it means to be considered the "other," and I did not like it.

Nobody cared about my grief

Wasn't this something that I wanted?

Then don't complain, don't share your losses

My grief became part of me,

I have had to equilibrate my identity to preserve it

When society wanted to erase it

My identity was forever changed,

my losses became my gains...

I grieved the losses of my culture, language, social relationships and privileges. This experience was so intense that my identity was affected. The losses that I experienced caused many internal conflicts that were also influenced by Canadian culture. I did know that I was mourning; my grief was invisible, not recognized by Canadian society. I had the first taste of what discrimination and oppression feel like; it was subtle sometimes no even felt until it was reflected upon.

I left Mexico with the idea one day to come back,

But I discovered the powerful grip that Canada had

I without realizing it, I fell in love with Canada idealism for social justice and acceptance.

That is why I became a social worker to offer grief support, to those that are lost, 
and to create a consciousness

of immigrant issues that need our awareness.

My identity was forever changed,

my losses became my gains...

My settlement process could have been easier if cultural bereavement programs and services were made available during my grief journey. The primary effect of these experiences was that I became self-aware of what I lost and what I gained. Those experiences influenced my identity. They influenced me to become a Social Worker and pushed me into the grief support field to assist individuals and families dealing with different types of losses. I wanted to offer to others want it was not offered to me when I needed the most.

Once I was grieving the loss of language, sooner I discovered the healing power, that speaking Spanish has for a social worker, helping immigrants and newcomers. How offering support in their language, opens the path to integration and acceptance. My identity was forever changed, my losses became my gains...

As a Social Worker, grief has sensitized; it has made me understand and care more deeply. Once I faced the covered racism and microaggression that exist about Latinas, it made me resist it. I embraced my accent; I felt empowered by my bilingualism. I saw the gap that exists in offering services in Spanish, and I saw how much newcomers yearned from the familiar sound in Spanish of welcome while receiving support services.

My identity has been forever changed... Overcoming obstacles associated with migration, Has brought awareness into my profession. It has been expanded like the palette of colours of a painter, Discovering colours unknown, with brighter tones Those experiences had increasing my awareness, of the circumstances faced by clients. My identity was forever changed, 
my losses became my gains...

I learned to accept and appreciate my conflicted identity. I have recognized the need to mourn my cultural losses, so I could be able to claim my humanity by integrating my many cultural and social influences into my new life in Canada. My personal experiences with grief have motivated me to apply grief support into my profession to issues of social justice related to cultural bereavement, loss and mourning, immigration and settlement. I decided to fight those systems that were working in oppressing me as a Latina immigrant. I decided to resist, what migration wanted to take away from me (my language, culture and traditions) I incorporated it into my practice. I refused to lose touch with the values and customs that shaped me to be who I am. I decided to apply them to connect with my clients to fight the system whit my cultural values, that is when my losses become my gains.

Despite the advances of my integration in Canadian society, I still feel surprised when my grief re-emerges, and it reminds me that cultural bereavement and migratory grief is a lifelong journey as an immigrant. Why is it so difficult then to move on, I wonder? After completing this study, I came with the conclusion that I am not, and maybe I will never be Canadian enough. Even though I have developed a sense of belonging to Canada, I still being seen and reminded subtlety on many occasions and in others bluntly that I am perpetually "othered."

\section{Participants}

I, under the lens of LatCrit, has invited Latinas to share their narratives, this study has given them space to freely communicate their unique experiences with migration and grief through the lens of their subjective stories. I decided to write an introductory paragraph about each participant and their poems with the intent of presenting the participants as creators of knowledge, and agents with unique life stories of strength. In this manner, the research is comprised of stories of 
resistance, not mere sources of data. The names of the participants have been changed; they were given a pseudonym to ensures confidentiality. Profiles are organized in the order in which the interviews were conducted. The following profiles present a brief synopsis of each participant story.

Participant 'A' - “Alinne” \& The Labyrinth of Pain

Alinne is a Latina woman that immigrated from Peru since she was a 7-years-old child. Alinne narrates, in her poem, the traumatic experience of leaving her "Abuelos" and everything that made her and defined who she was in her beloved Peru. Alinne shares in her poem "The Labyrinth of Pain" her grief and pain of emigrating to Canada to a mother, family and country that was unknown by her. Alinne, in her poetry, narrates her experiences and losses during and after her migration and how those experiences defined her grief and identity as Latina.

Participant 'B' - “Blanca” \& Doble Identity

Blanca emigrated from Mexico almost 17 years ago. Blanca expresses in her poem "Doble Identidad/ Doble Identity" her losses, her struggles during settlement, the challenges that she had to face as Latina in Canada. Blanca, in her poem, let us known how her migratory experiences have shaped her identity as a Latina woman and as a naturalized Canadian.

Participant 'C'- “Carla” \& Breaking out of my Cocoon

Carla immigrated to Canada from Mexico; her migration story is reflected in her poetry. In her poem, Carla narrates how her migratory journey has intersected with her immigration status, her experiences with domestic violence, her attachment to her country and, most importantly, her role as a mother. Carla defines herself as a "single mother" that is "sola"/ "esta sola" Carla 
commented that her children are her motivations to taking steps to heal from her experiences of loss and trauma.

\section{Poems}

Participants were given the option to write their poetic expressions in Spanish or English. All poems will appear firstly in the original language that they were created, and a translation to the other language will follow. Next, this study presents the poems written by the participants, organized in the order in which the interviews were conducted.

\section{"The Labyrinth of Pain" - Alinne}

Originally written in English

Mi abuelita y abuelito said you are ready for the road ahead!

We love you so much, our love will be with you always

No distance can separate how much we love you. Our bond is beyond distance

It is time to go. You have a long road ahead!

Where am I going? Why do I need to leave? Why are you Not coming? Why?

I do not want to go.... Please!

This moment was the first time I realized I had a heart...... [it]was in so much pain.

Lost in trying to understand the road ahead!

You have to understand no one puts their child on a plane to travel so far, unless the new destination promises a better future.

No one leaves home by choice, but we must!

I no longer felt the warmth of the sun on my skin. My world was gone.

I now felt the cold wind against my skin on the road ahead!

I no longer felt the love of my abuelita y abuelito.........gone forever on the road ahead!

My family was gone.... would I also disappear?

The little girl died--my identity died on that road ahead!

The minutes turned to hours, days, months, and years. I eventually forgot where I came from! The Labyrinth of pain was brought on by the road ahead!

[No] I do not want to stay here said the little girl. The woman said the road ahead is our home The years passed; my heart was filled with tears - as I got lost in the road ahead I no longer wanted to go home-my new home was found in the road ahead! On that road ahead-I am fully immersed in my new identity! 
But I see you in my dreams my abuelita y abuelito holding my hand I return home each time in my dreams...porque soy Latina!!

\section{Written by "Alinne"}

\section{"El Laberinto del Dolor"-Alinne}

Spanish Translation

¡Mi abuelita y abuelito dijeron que estaba lista para el camino por delante!

Te amamos mucho, nuestro amor siempre estará contigo

Ninguna distancia puede separar lo mucho que te amamos. Nuestro vínculo está más allá de la distancia.

Es tiempo de irse. ¡Tienes un largo camino por delante!

¿A dónde voy? ¿Por qué necesito irme? ¿Por qué no vienes? ¿Por qué?

No quiero ir.... ¡Por favor!

Este momento fue la primera vez que me di cuenta de que tenía un corazón ...... [estaba] con mucho dolor.

¡Estaba perdida en tratar de entender el camino por delante!

Tienes que entender que nadie pone a su hijo en un avión para viajar tan lejos, a menos que el nuevo destino prometa un futuro mejor.

Nadie sale de casa por elección propia, ipero debemos hacerlo!

Ya no sentía el calor del sol en mi piel. Mi mundo se fue.

¡Ahora sentía el viento frío contra mi piel en el camino por delante!

Ya no sentía el amor de mi abuelita y abuelito ........ ¡se fue para siempre en el camino!

Mi familia se había ido ... ¿Yo también desaparecería?

La niña murió, ¡mi identidad murió en ese camino por delante!

Los minutos se convirtieron en horas, días, meses y años. ¡Finalmente olvidé de dónde vengo! ¡El Laberinto del dolor fue traído por el camino por delante!

[No] No quiero quedarme aquí, dijo la niña.

La mujer dijo que el camino por delante es nuestro hogar.

Los años pasaron; mi corazón estaba lleno de lágrimas, mientras me perdía en el camino por delante

Ya no quería irme a casa, ¡mi nuevo hogar fue encontrado en el camino por delante!

En ese camino por delante, ;estoy completamente inmerso en mi nueva identidad!

Pero te veo en mis sueños mi abuelita y abuelito sosteniendo mi mano

iißRegreso a casa cada vez en mis sueños ... porque soy Latina!!!

Escrito por "Alinne" 


\section{"Doble Identidad" -Blanca}

Originally written in Spanish

Como inmigrante Latina, mi vida ha cambiado y definitivamente

no volverá a ser igual.

Deje mi familia, mis amigos, mi trabajo

y el futuro que tenía desempeñando mi carrera.

Las emociones son muy intensas

el conocer lugares; el conocer gente

sobre todo, cuando por lo menos hablan tu propio idioma

mucha frustración al no entender algo,

aunque hablaba el idioma

no hay mejor escuela que tener que sobrevivir...

Una alegría enorme conocer gente de tu país;

mucha tristeza de estar sola,

de ver cómo la gente quiere siempre aprovecharse de tu desconocimiento del sistema, como a veces la gente que debe apoyarte no lo hace

$\mathrm{y}$ te hacen sentir que no eres bienvenido o eres una carga.

¿Si hay ayuda para los inmigrantes porque nos hacen sentir basura cuando la necesitamos?

Ha habido momentos indignantes...

como cuando una trabajadora social originaria de mi país

me negó su apoyo para una entrevista de ayuda social

alegando que no le gusta la gente que abusa del sistema,

cuando yo no tenía más opción que tomarlo

o me quedaba sin un lugar para vivir y comer estando embarazada.

El estrés era constante

mientras aprendía hacia dónde dirigirme,

iba de un lugar a otro,

la gente te ve diferente,

no lo expresan abiertamente,

pero sabes que a muchos no le agradan los inmigrantes.

He aprendido a ser fuerte,

he llorado y me he desesperado,

la incertidumbre es terrible, 
pero sabes que tienes que salir adelante, tienes que pelear más por un trabajo ya que no tienes el privilegio de un color de piel que te ayude, y el acento...el acento que muchos pretenden no entender cuando pronuncias algo un poco diferente.

Me comporto diferente, sigo las reglas, mantengo la distancia, no puedo ser tan amigable, la gente no se presta para socializar, son a veces huraños y groseros.

No puedo visitar a los amigos que tengo porque aquí es la cultura de lo planeado, nunca de lo espontaneo...

En el trabajo se me ha criticado por hablar español con mis compañeros latinos. Esto es Canadá, y se habla inglés.

He adoptado las costumbres y tradiciones canadienses.

Mis hijos nacieron aquí y les inculco el amor por su país, les inculco el amor por el mío, aunque no lo entenderán nunca al 100 por ciento porque ellos no tienen el arraigo que yo tengo, pero les explico lo que significa para mí.

Han pasado casi 18 años y aquí sigo... soy un miembro productivo de la sociedad, me he incorporado y salido adelante, soy canadiense pero primero y siempre seré Mexicana.

$$
\text { Escrito por "Blanca" }
$$

\section{"Double Identity" -Blanca}

English Translation

As a Latina immigrant, my life has definitely changed 
it will never be the same.

I left my family, my friends, my job

and the future that I had with my career.

Emotions are very intense

Get to know places; meeting people

especially when they speak your own language too!

A lot of frustration at not understanding something,

although I spoke the language

there is no better school than having to survive ...

An enormous joy to meet people from your country;

much sadness to be alone,

sad to see how people always want to take advantage of your ignorance of the system,

sometimes the people who should support you don't do it

and they make you feel like you're not welcome or a burden.

If there is help for immigrants why they make us feel trash when we need it?

There have been outrageous moments ...

like when a social worker originally from my country

denied me support for a social aid interview

claiming that she doesn't like people who abuse the system,

when I had no choice but to take it

or I was left without a place to live and eat while pregnant.

The stress was constant

While learning where to go,

went from one place to another,

people see you differently,

they don't express it openly,

but you know that there are many that do not like immigrants.

I've learned to be strong

I have cried and I have despaired,

uncertainty is terrible

but you know you have to get ahead,

you have to fight more for a job

since you don't have the privilege of a skin color to help you,

and the accent ...

the accent that many pretend not to understand

when you pronounce something a little different. 
I behave differently, I follow the rules, I keep my distance I can't be that friendly people don't lend themselves to socialize, they are sometimes reclusive, cold and rude.

I can't visit the friends I have

because here is the culture of the planned, never spontaneous ...

At work I have been criticized

for speaking Spanish with my Latino colleagues.

This is Canada, and English is spoken.

I have adopted Canadian customs and traditions.

My children were born here and I instill in them love for their country, I instill in them love for mine, although they will never understand it 100 percent because they don't have the roots that I have, But I explain what it means to me.

Almost 18 years have passed and I'm still here ...

I am a productive member of society,

I have settled and got ahead,

I am Canadian but first and always will be Mexican.

Written by "Blanca" 


\section{"Breaking out of my Cocoon" -Carla}

Originally written in English

Base on my experience I can help other women

that are facing some difficult time in this situation

I will be so happy to share with you my story.

I have a back-ground as a Latina

I came to Canada because one of my friends invited me to come

I liked Toronto,

I knew that Canada was a beautiful Country,

with lot of opportunities to grow.

After some time, I considered that I want to live here,

I didn't have any idea how it will be

and all the challenges that I will be faced.

In my journey, I have had three challenges...

Migratory status

Dealing with mental issues

and being a single mother of two kids

First challenge was my status

I didn't have any idea how to be legal in this country

I started working

a daily race started in my life trying to survive.

After a while, I meet the father of my kids.

He is Turkish-Canadian

with his roots very strong

very different culture.

We got married after short period of dating

At that time, I didn't know he was faced some mental issues

he is bipolar with very strong issues.

As loving mothers and Latinas

we learn in our lives, that as women, we have to be with our man.

All the time. no matter what...

we always have to support them

we have to be strong

we are after all, the only person that can be for them. 
I had to live like this for more that 10 years

treats, domestic violence, addictions.

I have been raised by a Mom who loves too much!

I don't want my kids,

To have the wrong idea,

Of what a family is in this time

when you move to another country with different cultures

and being raised by only a mother.

At some point

I felt empty, alone

homesick,

missing my family

my life, my freedom

After many counselling and therapy for my self

I learn that I wasn't happy

I was not what I was expecting to be

with all the courage and strength

I understood that I deserve to live and move on with my two kids.

Finally, I made my decision to move on....

Written by "Carla"

\section{"Saliendo de mi Capullo'-Carla}

Spanish Transaltion

Basándome en mi experiencia, puedo ayudar a otras mujeres

que están en esta situación, pasando un momento difícil

Me alegro de compartir con ustedes mi historia.

Mi etnicidad es ser Latina

Vine a Canadá porque uno de mis amigos me invitó a venir

Me gustó Toronto

Sabía que Canadá era un país hermoso

con muchas oportunidades para crecer.

Después de un tiempo,

consideré que quería vivir aquí, 
No tenía idea de cómo seria

y todos los desafíos que enfrentaría

En mi viaje, he tenido tres desafíos ...

Estado migratorio

Tratar con problemas mentales

y ser madre soltera de dos hijos

El primer desafío fue mi estado migratorio

No tenía idea de cómo ser legal en este país

Empecé a trabajar

empezó una carrera de todos los días, tratando de sobrevivir.

Después de un tiempo,

me encuentro con el padre de mis hijos.

El es Turco-Canadiense

con sus raíces muy fuertes

Cultura muy diferente.

Nos casamos después

de un corto período de citas.

En ese momento, no sabía que tenía problemas mentales.

Él es bipolar con problemas muy fuertes.

Como Madres amorosas y Latinas aprendemos en nuestras vidas, que las mujeres tienen que estar con su hombre.

Todo el tiempo. no importa qué...

siempre tenemos que apoyarlos,

tenemos que ser fuertes,

después de todo, somos la única persona que puede ser para ellos.

Tuve que vivir así durante más de 10 años

Maltratos, violencia doméstica, adicciones.

¡Fui criada por una Madre que ama demasiado!

No quiero que mis hijos,

tengan una idea equivocada

de lo que es una familia,

cuando te mudas a otro país con diferentes culturas

y siendo criado solo por una madre.

En algún momento 
Me sentí vacía, sola, nostálgica, extrañando a mi familia,

mi vida

mi libertad.

Después de muchos asesoramientos y terapia Aprendí que no era feliz

No era yo lo que esperaba ser

Y con toda valentía y fortaleza

comprendí que merecía vivir y seguir adelante con mis dos hijos.

Finalmente, tomé la decisión de seguir adelante ...

\section{Escrito por "Carla"}

\section{Narrative Themes}

In the following section, I discuss the themes that result from the poetic expression and the interviews with the participants. There was a recurrence of themes in the participants' poems despite them being expressed differently according to the social location of the participants. The semi structures interviews presented the themes founded in the poems from a deeper perspective. After analyzing those themes, I highlight five prominent themes; the cumulation of grief, losses and stress guide migration, cultural values dictate Latinas settlement, changes in identity, struggle with oppressive systems and resistance and resilience.

During this analysis, fragments of the poems will be presented in italics and will appear entirely in their original language. An English translation will follow poems or phrases in Spanish. Poems or phrases originally written in English will be presented only in English. Phrases that are written with "quotation marks" indicate the verbal comments of the participants.

Each theme is presented individually, including one or two representative fragments of the poems as well as fragments of the participants' voices from their oral narratives describing the 
theme. The poems may contain spelling mistakes because I have preserved the original writing of the participants.

\section{The cumulation of grief, losses and stress guides settlement}

A communality on the three poems and conversations with the participants is their description of how the experience of migration has brought a cumulation of losses that have impacted their grief and acculturation to Canada. As Latinas, the intensity of the participants' experiences varies according to their social location. However, what they have in common is the profound mark that their losses and their migratory journey have left in them.

"Solo los que han emigrado saben lo que duele" / "Only those who have migrated understand how much it hurts," Blanca commented while reflecting on the profound impact that migration has in the lives of Latinas.

In the case of Alinne, she expressed in her poem the pain and loneliness that she felt after being separated from her grandparents:

Mi abuelita y abuelito said you are ready for the road ahead!

We love you so much, our love will be with you always

No distance can separate how much we love you. Our bond is beyond distance

It is time to go. You have a long road ahead!

Where am I going? Why do I need to leave? Why are you Not coming? Why?

I do not want to go.... Please!

This moment was the first time I realized I had a heart....... [it]was in so much pain.

Lost in trying to understand the road ahead! - "Ana"

Blanca recognized in her poem the many losses that Latinas grieve when immigrating and how the process changes their lives.

Como inmigrante Latina, mi vida ha cambiado y definitivamente no volverá a ser igual.

Deje mi familia, mis amigos, mi trabajo y el futuro que tenía desempeñando mi carrera. 
[English] As a Latina immigrant,

my life has definitely changed

it will never be the same.

I left my family, my friends, my job

and the future that I had with my career

Blanca's most profound losses were her family, friends, her job and her professional career.

Blanca studied psychology in her home country when she emigrated to Canada one loss that she had to grieve was her profession. Blanca discovered that her profession was not valid in Canada:

“Aquí mi carrera no era válida / Here my profession was not valid’. "Tenía que empezar de nuevo y no podía darme ese lujo. Había que trabajar para sobrevivir / I had to start again and I couldn't give me that luxury. I had to work to survive"

Blanca further elaborated during the interview about her experience of losing her career as a Latina woman:

"Después de todo lo que estudie y venir aquí y que me digan que no vale y que tengo que estudiar de nuevo. /After everything that I studied, I come here so they can tell me that my career is not valid, and I have to start again."

Those statements present an overview of the unexpected symbolic, intangible losses that Latinas confront during their settlement process. Those losses contribute to their bereavement and aggravate their grief process that is already mourning the losses caused by migration.

Blanca continued:

¿Como que no cuentan mis estudios? Aquí en este país borran tan fácil todo lo que uno ha logrado. How come that my studies are not valid? / Here in this country they so easily erase everything that one has achieved." Furthermore, Blanca narrative showed how her losses were exacerbated by the erasure of her professional identity and ignored by Canadian society. 
Meanwhile, Carla, in her poem, narrated what she lost and how she felt and when she immigrated to Canada:

missing my family

my life, my freedom

At some point

I felt empty, alone

homesick,

Carla felt homesick and alone, isolated from her family, she immigrated to Canada because she had the expectations that Canada will offer her many opportunities to success:

I have a back-ground as a Latina

I came to Canada because one of my friends invited me to come

I liked Toronto,

I knew that Canada was a beautiful Country,

with lot of opportunities to grow.

After some time, I considered that I want to live here,

I didn't have any idea how it will be

and all the challenges that I will be faced.

Carla narrated, in her poem the challenges that she faced during her migration:

In my journey, I have had three challenges...

Migratory status

Dealing with mental issues

and being a single mother of two kids

Carla elaborated, during the interview how her migratory status, the loss of her freedom due to being trapped in a violent relationship hindered her settlement:

"I came as a visitor and decided to stay. I did know how to apply for a resident visa, so I was illegal, I had to hide and work hard to survive. Then I met my husband; he was Canadian. He promised to sponsor me. He had some mental problems. He was violent, I could not get out, he controlled me, he threatened to deport me and take my kids away from me." 
The pain and isolation of immigration bring stress to the settlement of Latinas, and it can be exacerbated by their social location and structures of oppression. Alinne described how profound was the pain of leaving her "Abuelita and Abuelito"/Grandmother and Grandfather when she was seven-years-old;

"My grandparents raised me, and my Mom was a distant memory. She was not real, but my grandparents were real. I was surrounded by my extended family, my uncles, my aunts, and my cousins. I was very very loved. I never question love at all because I felt their love. When my Mom sent from me and took me away from them, I lost my connection with my family, my country, even my language. I was not able to go back until many years later."

Blanca brought up the topic of stress and trauma as effects of migratory grief by reflecting on how her settlement process was complicated due to the losses and stress caused by her migratory experiences. In her poem, Blanca talked about how the stress was a constant in her settlement life:

El estrés era constante

mientras aprendía hacia dónde dirigirme, iba de un lugar a otro.

[English]

The stress was constant

While learning where to go went from one place to another.

Distress during migration has a direct relation with a range of psychological effects. Blanca felt that the challenges during pre-migration, during migration and post-migration caused her stress and anxiety. She elaborated further during the interview:

"Si no hubiera tenido que empezar de cero, mi vida aquí hubiera sido mas fácil; sin tanta ansiedad, sin tanto estress. / If I had not start from zero, my life here would have been easier; without so much anxiety stress, without so much stress." 
Blanca, during the interview, connected her challenges with migration as a source of her constant stress and anxiety. Moreover, Blanca reflected that if the process of the settlement was easier, the level of stress and anxiety would have dismissed as well.

\begin{abstract}
Alinne adds to the topic describing as "traumatic" her immigration experience:
"If I touched back on what happened to me, there is an enormous loss, and the loss is your identity who you are, so that person that I knew That little girl was lost when she went up in the plane. The person that arrived in Canada was a different person. Now that I reflect on this, it was so traumatic losing them. It was so painful leaving them then that little girl had to disappeared to continue her new life in Canada."
\end{abstract}

According to Alinne, the losses of her Grandparents, extended family, and her way of life in Peru were very painful, making a deep impact on her well-being. She had to block those memories, to erase her old herself to be able to survive and settle in Canada:

"I lost so much, but I think that unconsciously I forced myself to forget because it was too painful for me to cope. I focused on how to survive in this new country and how to fit in with my family" Alinne exposure to traumatic events during her migration had a direct relationship with her disconnection of herself and the anxiety that she suffered during her settlement.

Carla contributed to the theme by describing her settlement experiences as traumatic as well. However, in her case, she reflected that it was influenced by the uncertainty of her immigration status, domestic violence and her fear of being separated from her children:

"It was a trauma. I was isolated from my family, I did know the laws, the customs here, I did have any support. I could not go back home due to... mi [migratory] status and the violent relationship that I had with my ex-husband. He constantly scared me... threaten me 
that he will not be sponsored me, and he will take away the kids. I lived in constant fear of being deported and losing my children.”

For Blanca, the stress generated during her settlement was traumatic as well. She realized that it was generated not only by her migratory losses but also by the systemic oppression that she felt contributed to hinder her acculturation and settlement in Canada:

“Aquí tu vida te cambia, nunca más es la misma tuve que enfrentar situaciones humillantes como inmigrante y Latina, el sistema en Canadá te hace sentir que no perteneces, te aísla. Me sentí aislada, estigmatizada. Esas experiencias fueron un shock, super estresantes... traumáticas. / Here your life changes you, it is never the same. I had to face humiliating situations as an immigrant and as a Latina. The system in Canada makes you feel like you don't belong, it isolates you. I felt isolated, and stigmatized. Those experiences were shocking, very stressful...traumatic."

Participants recognized in their narratives the different psychical and symbolic losses that they encountered during their immigration journey to Canada. They also reflected on their grief and feelings of loneliness, sadness, and homesickness that they faced during their migration. Their social location influenced their migratory grief experiences although unique; however, they have the commonality that their process of acculturation was guided by trauma and stress generated by the multiple losses that originated by their migration.

\section{Cultural values dictate Latinas settlement}

The participants narrated in their poems their experiences of cultural bereavement and its intersection of their cultural values, gender roles and their settlement. The values and traditions of Latinas are firmly attached to their culture, dictating their experiences with cultural bereavement. The value of familismo had a huge influence on their bereavement. For Alinne, family ties for 
Latinas were a fundamental part of her identity. The loss of her "Abuelos/Grandparents," extended family, the love and nurture that they provided to her was irreparable. In her poem, she elaborates:

You have to understand no one puts their child on a plane to travel so far, unless the new destination promises a better future.

No one leaves home by choice, but we must!

I no longer felt the warmth of the sun on my skin. My world was gone.

I now felt the cold wind against my skin on the road ahead!

I no longer felt the love of my abuelita y abuelito.........gone forever on the road ahead!

After losing her family ties with her "Abuelos/Grandparents" Alinne, could not reestablished those closed ties with her Mom and new family in Canada. Her bereavement was complicated by the loss of connections with her Mom:

"I felt like I was adopted. I never felt love, the love that my grandparents gave me, that closeness was gone. I tried to connect with my family. I did not have that connection with my Mom, but my Mom never hugged me like' I am happy to have you' or' I love you" or kissed me. I do not remember any of that, nothing, I lost it. I never had that. I just remember a feeling of loss...

In the case of Blanca, her refugee status meant that she could not go back to her country.

She was close to her family and missed the connection to her roots. Blanca yearned for that connection while meeting other Latinos that spoke Spanish:

Las emociones son muy intensas

el conocer lugares; el conocer gente

sobre todo, cuando por lo menos hablan tu propio idioma

[English]

Emotions are very intense

Get to know places; meeting people

especially when they speak your own language too!

Blanca tried to re-established social ties with friends from the Latino diaspora as a measure to counteract her bereavement. 
Una alegría enorme conocer gente de tu país;

mucha tristeza de estar sola

[English]

An enormous joy to meet people from your country;

much sadness to be alone,

However, those relationships lack the closeness that they had in her country. Her social relationship here in Canada, even between Latinos were influenced by the cultural values and norms of the host country.

No puedo visitar a los amigos que tengo

porque aquí es la cultura de lo planeado, nunca de lo espontaneo...

[English]

I can't visit the friends I have

because here is the culture of the planned, never spontaneous ...

Blanca was left homesick with a sense of never fully belong, mourning the closeness, warmth, and spontaneity that exists in the familismo value:

"Extraño esa cercanía de la familia, el apoyo de tenerlos cerca si necesitas algo o en una emergencia. Los mexicanos somos muy alegres, tus amigos se vuelven parte de tú familia, hay mucha cercanía, puedes visitarlos cuando quieras. Aquí en cambio son muy fríos, tienes que hacer cita para verte! / I miss that family closeness, the support of having them around if you need something or if you have an emergency. Mexicans are happy people; your friends become part of your family, there is much closeness, you can visit them whenever you want. Here they are very cold; instead, you have to make an appointment to see them.”

Cultural values provide Latinas with a sense of identity, purpose, and meaning in life. The value of marianismo was also part in the bereavement process of the participants. In Carla 
situation, the values of familismo and marianismo intersected to exalt her role as a mother and nurturer. Carla found solace by closing ties with her nucleus family here in Canada after leaving a violent relationship. She wrote in her poem:

I don't want my kids,

To have the wrong idea,

Of what a family is in this time

when you move to another country with different cultures

and being raised by only a mother

Carla elaborated:

"I had to be strong and be there for my family, my kids. I am a mother of two, raising them as a single mother. I want my kids to learn what it means to be a family that supports each other, that loves each other."

Marianismo influenced the experiences of participants by shaping their perception of traditional gender roles as a mother and as a wife. Carla wrote in her proem about how she perceived herself based on the value of marianismo:

As loving mothers and Latinas

we learn in our lives,

that as women, we have to be with our man...

Marianismo values exalt motherhood; however, this value also influences the gender roles of submission and self-sacrifice of Latinas. Carla described how the values of marianismo influenced her attitude in her marriage.

We got married after short period of dating At that time, I didn't know he was faced some mental issues he is bipolar with very strong issues

All the time. no matter what... we always have to support them 
Blanca shared during the interview that in her case, she made the sacrifice to stay home after she gave birth to her children as a way to support her husband, however that sacrifice let her feel even more isolated:

"Después de tener a mis niños, decidimos que me quede en casa, aunque con muchos sacrificios era menos costos que encontrar un trabajo mal pagado. Aparte no teníamos dinero para una guardería. Fue muy difícil, no tenía apoyo, me sentía muy sola no contaba con ayuda. Cuando mi esposo llegaba a casa no contaba con él para ayudarme con los niños. pues trabaja mucho y estaba cansado. Era yo la responsable de todo. / "After having my children, we decided that I will stay home, although with many sacrifices it was less costly than finding a poorly paid job. Also, we didn't have money for a daycare. It was very difficult; I had no support. I felt very lonely and I did not have help. When my husband came home after work, he didn't help me with the children. Well, he worked a lot and was tired. I was responsible for everything."

Carla explained that she felt that men have moral authority and control on their family, and her role was to keep the family together:

"I was raised like that; my Mom was like that. I learned than the husband is the head of the family. As a woman, I had to support my husband, no matter what. I had to keep the family together for the sake of the kids."

Simpatica value inspires Latinas to be friendly, caring, generous and kind. The endorsement of the traditional gender role of Latinas in their cultural values influences them to be forgiving even in despise of struggles and violence as well as to comply with social expectations and subordination that, in many cases, can negatively impact them. Carla continued:

we have to be strong

we are after all, the only person that can be for them 
Carla elaborated:

“As a Latina, in Mexico, I saw my Mom loving my Dad too much. I was taught that I had to forgive and to love him. My love would change him, make the marriage work, to sacrifice myself for him for the sake of our marriage."

Another aspect of cultural bereavement was that participants felt restricted to practice their cultural values. Blanca commented that she could not be as "simpatica" and friendly as she would like because in Canada it is not tolerated:

“Aquí no puedes ser muy amigable porque es mal visto, lo ven como invasión a su privacidad. En este país debes de controlarte y ser frio. / Here you cannot be very friendly because it is frowned upon, they see it as an invasion of their privacy. In this country, you must control yourself and be cold."

She writes about her experience in heir poem:

Me comporto diferente, sigo las reglas, mantengo la distancia, no puedo ser tan amigable, la gente no se presta para socializar, son a veces huraños y groseros.

[English]

I behave differently,

I follow the rules,

I keep my distance

I can't be that friendly

people don't lend themselves to socialize, they are sometimes reclusive, cold and rude.

The values of familismo, marianismo and simpatica intersect influencing the migratory experiences of Latinas. Carla explained the negative impact of the influence of marianismo and simpatica values in her role as a Latina. 
I had to live like this for more that 10 years

treats, domestic violence, addictions.

I have been raised by a Mom who loves too much!

Carla expanded her comments:

"I have a Mom that loves to much! I saw how she interacted with my father. I was taught that I have to be there for my family, that I have to do everything to save the family, to forgive. For more than ten years I was abused, I had to deal with his addictions, he was bipolar. I felt so alone.”

Alinne saw the intersection of values in her experiences with her family here in Canada: "I wanted to fit in, in this country in the school, with my family, with my Mom, I tried to fit but with her... [Mom] I couldn't do it. My Mom was no close to me, she never hugged me or said I love you... It made me feel as I was not her daughter; I was a stranger.”

Latino cultural values are a set of attitudes and behaviours that establish gender norms in Latinas dictating their attitudes, experiences and viewpoints influencing their bereavement stories. The values and traditions of Latinas are firmly attached to their culture, dictating how they perceived themselves in their gender roles and how they uphold those traditional norms during their migration.

\section{Changes in identity - The identity of Latinas straddle two worlds: where they came from and where they live.}

The many losses and challenges that come with migration influence participants' identity and concepts of self. The migratory transition of Latinas can be traumatic, influencing their grief and dictating their experiences. Often Latinas do not count on the resources to support them with their migratory grief. Due to the grief and trauma of immigration, their identity is forever changed. Moreover, in many cases, it is even lost. 
For Alinne, her migration process was so traumatic that her identity and concept of self as

Latina were lost. She wrote:

My family was gone.... would I also disappear?

The little girl died--my identity died on that road ahead!

The minutes turned to hours, days, months, and years.

I eventually forgot where I came from!

The Labyrinth of pain was brought on by the road ahead!

Alinne felt that she needed to create a new identity that was fully acculturated to Canada, forgetting her Latina identity. Alinne wrote:

I no longer wanted to go home-my new home was found in the road ahead!

On that road ahead -I am fully immersed in my new identity!

Alinne elaborated:

"I had to adjust to a new culture, a new family, a new language. I was in so much pain missing my Abuelitos /Grandparents" that I think to forget what happened. It was my way to cope with the trauma of leaving my grandparents. I had to forget who I was. Now I feel ready to share this. I am reconnecting again with that part of me, the Latina in me.”

Alinne continued:

"If I touched back on what happened to me, there is an enormous loss, and the loss is your identity, who you are, so that person that I knew, that little girl was lost when she went up in the plane. The person that arrived in Canada was a different person."

For Blanca, her identity as Latina was in permanent conflict with the culture and values of the host country. She resisted her acculturation as a way to retain her cultural values and prevent more losses. She felt that her identity was in permanent conflict. 
Over the years, her identity was shaped by her assimilation of Canadian culture and her Latin American values. Blanca found a duality that exalts her culture while including the influences of Canadian culture. She described it:

"Le pongo a mi poema el nombre de "doble identidad" porque eso es lo que me ha pasado con el paso de los anos. Mi identidad se ha transformado en dos partes que conforman una misma. Al principio cuando llegue, era tanto mi duelo que me resistía a otras influencias incluso positivas ahora que el tiempo ha pasado y mis hijos han nacido aquí he incorporado ciertos aspectos de la cultura canadiense en mi identidad. He tomado lo mejor de Canadá y lo he incorporado a mi identidad como Mexicana y Latina. / "I gave my poem the name of "double identity" because that is what has happened to me over the years. My identity has been transformed into two parts that make up one. In the beginning, when I arrived, my grief was so profound that I resisted other influences, even positives ones. Now that time has passed, and my children have been born here, I have incorporated certain aspects of Canadian culture into my identity. I have taken the best of Canada and have included it in my identity as Mexican and Latina.

Carla felt as well that her identity was constantly influenced by Canadian culture; she is trying to balance those influences with her Latina identity:

"Después de todo lo que he pasado, con mucho esfuerzo estoy saliendo adelante, quiero para mis hijos que estén en contacto con México, con la familia que tengan ese apoyo, pero también que se sientan bien de vivir en Canadá. No quiero que se pierdan mis raíces, aunque es difícil pues aquí estanos solos rodeados de la cultura Canadiense / After everything that I have been through, with a lot of effort I am finally moving forward. I want my children to be in contact with Mexico, with the family that they have that support, but 
also that they feel good about living in Canada. I do not want my roots to be lost although it is difficult because here, we are alone surrounded by Canadian culture.”

The identities of Latinas are multidimensional. They are influenced by not only their gender, nationality and social location but also by their losses and grief experiences with migration and settlement. The identities of Latinas are forever changed after migration.

\section{Struggle with oppressive systems - "No eres bienvenido o eres una carga /Either you are not welcome, or you are a burden."}

The title of this section, "no eres bienvenido o eres una carga / either you are not welcome, or you are a burden," originated from Blanca's poem and story. In this short paragraph of her poem, Blanca highlighted the topics to be covered in this section; racism, discrimination and antiimmigrant sentiment:

mucha tristeza de estar sola,

de ver cómo la gente quiere siempre aprovecharse de tu desconocimiento del sistema, como a veces la gente que debe apoyarte no lo hace

y te hacen sentir que no eres bienvenido o eres una carga.

¿Si hay ayuda para los inmigrantes porque nos hacen sentir basura cuando la necesitamos?

[English]

It is sad to see how people always want to take advantage

of your ignorance of the system,

sometimes the people who should support you don't do it

and they make you feel like you're not welcome or a burden.

If there is help for immigrants why they make us feel trash when we need it?

Blanca commented how Latinas are classified and perceived in Canada based on prejudice and stereotypes:

“Aquí en Canadá no eres bienvenido o eres una carga. Esperan que como Latina tu trabajo sea de limpieza o cualquiera de esos trabajos que creen que hacen los Latinos. Les 
sorprende que seas una mujer preparada. Y si tienes la mala suerte que necesitas apoyo y solicitas ayuda, te tratan mal, te humillan y creen que como eres Latina estas tomando ventaja del sistema. / Here in Canada, they expect that as a Latina your job is to clean or to do any other type of job that they think Latinos do. It surprises them that you are an educated woman. If you have the bad luck to need support and you ask for help, they [Canadians] treat you very bad, they humiliate you and think that you are abusing the system."

In her poem, Blanca gave to examples of how anti-immigrant sentiment, racism and discrimination is embedded in daily micro-aggressions in Canadian society:

la gente te ve diferente,

no lo expresan abiertamente,

pero sabes que hay muchos que no le agradan los inmigrantes.

[English]

people see you differently,

they don't express it openly,

but you know that there are many

that do not like immigrants.

Another example is how racism toward Latinas applies in the job force:

tienes que pelear más por un trabajo

ya que no tienes el privilegio de un color de piel que te ayude,

y el acento...el acento que muchos pretenden no entender

cuando pronuncias algo un poco diferente.

[English]

you have to fight more for a job

since you don't have the privilege of a skin color to help you,

and the accent ...

the accent that many pretend not to understand

when you pronounce something a little different. 
As women, Latinas deal with numerous difficulties. Then again, their intersection as a race group made them faced unique barriers. Blanca talked about how stigma and stereotypes against Latinas intersect with systemic racism and antimigrant sentiment in social services to oppress them.

Ha habido momentos indignantes...

como cuando una trabajadora social originaria de mi país

me negó su apoyo para una entrevista de ayuda social

alegando que no le gusta la gente que abusa del sistema,

cuando yo no tenía más opción que tomarlo

o me quedaba sin un lugar para vivir y comer estando embarazada.

[English]

There have been outrageous moments ...

like when a social worker originally from my country

denied me support for a social aid interview

claiming that she doesn't like people who abuse the system,

when I had no choice but to take it

or I was left without a place to live and eat while pregnant.

Blanca delved into the topic:

"Fue indignante, muy humillante...Tenia la necesidad de aplicar por un servicio social. No estaba ahí por gusto, pero me toco una trabajadora social que había emigrado de mi país, que hablaba español, pero en vez de comprender la situación tan difícil en la que estaba pasando por esos momentos. / It was outrageous, very humiliating ... I had the need to apply for a social service. I was not there for pleasure, I got a social worker who had emigrated from my country, who spoke Spanish, but instead of understanding the difficult situation in which I was going through those moments.

"Decidió humillarme diciendo que aquí no les gustaban los Latinos que abusaban del sistema. Asumió que nosotros íbamos a abusar del sistema también. Como si todos fuéramos iguales. Me puso muchos obstáculos para que yo aplicara y recibiera el servicio, 
me la hiso difícil. Me sentí como si estuviera pidiendo limosna. Tuve que aguantar todas esas humillaciones porque si no me quedaba sin comer y estaba embarazada... / " She humiliated me by saying that here in Canada they don't like Latinos who abused the system. She assumed that we were going to abuse the system too. As if we were all the same. She put a lot of obstacles for me to apply and receive the service. The social worker made the process so difficult for me. I felt like I was a beggar She put many obstacles for me to apply and receive the service, making it very difficult for me. I felt like I was begging. I had to put up with all those humiliations because if I didn't do it, I was going to be left out without eating and I was pregnant ...”

Blanca experiences of discrimination from the Latina social worker shown that, in some cases, the efforts of immigrants to adapt to their host country may include the acceptance of the dominant society's racism towards their own race and ethnicity.

Carla added to the topic of anti-immigrant sentiment:

After some time, I considered that I want to live here, I didn't have any idea how it will be and all the challenges that I will be faced.

Carla explained: "I had an idea of Canada to be so welcoming, the reality is different, especially if you do not have papers, if you are Latina and don't speak English, they accept your less. Your life is very difficult."

Carla continued:

"I was threatened to be reported, as Latina without visa there is more danger., there are people who report you, and as a Latina, you are more at risk. I did not know that there were support services that I could ask for help to fix my status. I was told that the only way was through my ex-husband sponsorship; he used that against me." 
Even though Alinne immigrated to Canada since she was seven-years-old, the stereotypes of being Latina continued in her daily interactions: "People expected me to be the type of Latina that fits their stereotype. They are surprised if I don't like something that Latinas are supposed to like or if I don't behave as Latinas are supposed to do."

The narratives of Latinas showed that based on their gender and race, they encountered many barriers of oppression that impacted their migration journey.

\section{Resistance and Resilience}

There are loss and grief but also resilience and resistance in the migration process. Based on the stories of the participants asserting their ethnicity as Latinas is the vital importance, they resisted the "erasure" of their identity and culture by their host country in different ways. They used different copying factors as resilience.

For Blanca, one of the ways to resist is to challenge dominant discourse by being part of this study:

"Hice mi poema en español porque si voy a contar algo tan doloroso no hay nada mejor que hacerlo en mi idioma. Aparte me gusta la idea que sea presentado en su idioma original... el español por que este estudio es de Latinas. / I made my poem in Spanish because if I am going to tell something so painful there is nothing better than doing it in my language. Besides I like the idea of it [poem] being presented in its original language [Spanish]... because this study is from Latinas."

For Carla, her way of resisting was completely the opposite way:" I wrote my poem in English because I have worked very hard in learning this language, and also, I wanted to show the ability that Latinas have of being bilingual." 
For Alinne, her way of resisting was to reconnect with that Latina identity that was lost when she as a child separated from her beloved grandparents, family and her country:

But I see you in my dreams my abuelita y abuelito holding my hand I return home each time in my dreams...porque soy Latina!!

She elaborated during her interview: "I have come to terms with my past. I am reconnecting with that Latina part within myself. I feel that I am ready to confront my past. To reconnect with that part of me, that died"

Despise the immigration-related challenges that the participants encountered in their journey. They have been able not only to resist but to develop resistance. These protective factors interconnect to challenge subordination, oppression while empowering Latinas to keep their ties to their cultural values and identity.

For Blanca resistance and resilience had help her to keep strong ties to her culture, her children and to feel proud about her identity. She wrote in her poem:

Mis hijos nacieron aquí y les inculco el amor por su país, les inculco el amor por el mío, aunque no lo entenderán nunca al 100 por ciento porque ellos no tienen el arraigo que yo tengo, pero les explico lo que significa para mí.

Han pasado casi 18 años y aqui sigo... soy un miembro productivo de la sociedad, me he incorporado y salido adelante, soy Canadiense pero primero y siempre seré Mexicana.

[English] My children were born here and I instill in them love for their country, I instill in them love for mine, although they will never understand it 100 percent because they don't have the roots that I have, But I explain what it means to me.

Almost 18 years have passed and I'm still here ... I am a productive member of society, I have settled and got ahead, 


\section{I am Canadian but first and always will be Mexican}

She commented:

"Para mí es muy importante enseñarles a mis hijos las tradiciones de mi país, porque en cierta manera México también es su país, aunque no hayan nacido allá es importante que las conozcan para que no se pierdan. / For me it is very important to teach my children the traditions of my country, because in a certain way Mexico is also their country, although they were not born there, it is important that they get to know them [traditions] so that they do not get loss.

Blanca continued:

"Se necesita mucho coraje para seguir adelante como Latina en este país cuando casi todo está en tu contra, pero aun así si trabajas duro puedes lograr una vida mejor / It takes a lot of courage to keep going as a Latina in this country when almost everything is against you but even with those difficulties if you work hard you can achieve a better life." “A pesar de todo he salido adelante, he vencido muchos obstáculos. Aunque ya soy Canadiense primero que nada siempre he sido y seré Mexicana. / I have persevered despise of everything that happened. I have overcome many obstacles. Although I am Canadian, first of all I have always been and will be Mexican."

Carla explained that she resisted by reconnecting with her traditions: "If you don't pass on your traditions, they [the children] would not know them."

Carla reflected in her resistance and resilience as protective factors in her poem:

After many counselling and therapy for my self

I learn that I wasn't happy

I was not what I was expecting to be

with all the courage and strength

I understood that I deserve to live and move on with my two kids.

Finally, I made my decision to move on.... 
Carla further elaborated about her experience:

"I decided to do something about the violence at home. I was not happy; I was not the woman and Mom that I wanted to be. Therapy helped me to face the horrible situation that my kids and I were living. I needed to leave; although I was fearing so much that step, I had to heal and to protect my family. I had to be strong for my two kids, and I did it. I feel so proud of myself.

Carla said that now she wants to pay it forward, to tell her story to other Latinas that may be facing a similar situation so they are better prepared and can ask for help. She wrote in her poem:

\section{Base on my experience I can help other women}

that are facing some difficult time in this situation

I will be so happy to share with you my story.

She elaborated:

"Now, being part of this research, I want to help other Latinas through my story. I hope that by reading my story can prevent suffering to other Latinas. Que sepan que a pesar de las tragedias se puede salir adelante. / Let them know that despite the tragedies, you can move forward with you live."

The participants, as Latinas, have reacted with resilience to multiple sources of oppression in their migratory journey. They have resisted and tried to overcome oppressive challenges during their settlement. 


\title{
CHAPTER 6
}

\section{DISCUSSION \& CONCLUSION}

\author{
When you finally arrived al norte. \\ You found yourself alone, \\ Without family or the language. \\ Alone, with a fistful of dreams and hope. \\ -Ana - "Manojo de sueños" (Christoph, 2014)
}

\section{Introduction}

Throughout this chapter, I have used a Latino Critical Race (LatCrit) perspective to discuss the findings of this study. A discussion of the themes with a connection to the literature will be presented in this chapter. It will be followed by the implications and limitations of the study. A series of recommendations based on findings will be suggested. Finally, the conclusion of this research will be presented.

\section{Discussion}

The present study was conducted to explore the impact and effects of migratory grief among Latinas and its effect on their identity and well-being. The findings drew on the lived experiences of Latina women and their stories of migratory grief. The themes found in this study indicated that migratory grief impacts their identity, well being and settlement experiences of Latinas in Canada. In this discussion, Latino Critical Race Theory (LatCrit) was used to analyze Latinas stories to connect their experiences with the findings.

LatCrit is rooted in the tenets of storytelling, each voice of colour is unique, and race is socially constructed. Under those LatCrit tenets this discussion will present the themes found in this research recognizing the experimental knowledge of women of colour (Latinas), challenging preestablish research paradigms and by deconstructing issues of race that subordinate Latinas experiences during their immigration (Solórzano \& Yosso, 2000) 
This research honours those principles by presenting the perspectives of Latinas in their own voices through poems written by them and by their conversations. The perspectives of Latinas in this study are based non only on their immigration stories and gender but on their social identity and the intersection of multiple layers of subordination that shapes their experiences with migratory grief of the participants narrating their stories. The analysis of the findings presented five themes; the cumulation of grief, losses and stress guides their process of acculturation, cultural values dictate Latinas settlement, changes in identity, struggle with oppressive systems and Resistance and Resilience. This discussion will present the themes found in the analysis under a LatCrit lens.

\section{The cumulation of grief, losses and stress guides their process of acculturation}

The experiences of Alinne, Blanca and Carla with migratory grief are unique. The grief of each one of the participants is complex, flexible and multidimensional, and it is based on their social location (Casado et al., 2010; Gonzalez; 2005; Perry, 2010). However, there are some commonalities in their stories. Alinne, Blanca and Carla spoke about the thread of loss, the shock, stress and trauma that they felt during their migration journey and settlement. Gastaldo (2014) argues that in Canada, the process of migration for newcomers is determined by economic, social, cultural and personal losses and influenced by bereavement suffered during their immigration journey (p.62). Furthermore, based on this study's findings, the stress caused by migratory grief and accumulations of losses in Latinas during their migration impacts their settlement in Canada.

The literature argues that grief is a commonality in migration. Migratory grief is a universal thread in immigrants that lead to multiple types of losses (Ayala \& Dalouh, 2014; Casado \& Leung, 2001; Diaz, Molina, \& Marín, 2015; Gonzalez, 2005; Perry, 2010; Stroebe, \& Blink, 2008 ). Research has demonstrated that for Latinos, their migratory grief is often neglected, and it can lead 
without support to negative effects in their well-being if left unresolved (Casado et al., 2010; Gonzalez, 2005; Moya et al., 2016; Perez \& Arnold-Berkovits, 2018). Other studies argued that a correlation exists between migratory grief and the process of acculturation of Latinos in their host country (Ayón et al., 2017; De Snyder, 1987; Gil, \& Vega, 1996;). Regarding the experiences of Latinas with migration, some studies had focused on their migratory grief. Those studies focused their research on the experiences of Latinas immigrants in the United States. They argue that the impact of their grief is related not only to their gender but to oppressive structures in their host country. (Hondagneu-Sotelo 1992; Horton, 2009; Perez \& Arnold-Berkowitz, 2018; Renfroe, 2018; Valencia-Garcia, \& Kim, 2017). However, the impact of the stress and cumulation of losses caused by the intersection of migratory grief and structures of oppression in Latinas during their settlement in Canada is not yet fully recognized in Canadian research.

Under the lens of LatCrit, Santos (2019) found that stress, the trauma of migration and cultural shock shapes the experiences of Latinas immigrants (p.13). A commonality in the findings of the three participants was that the stress prior and during migration was aggravated by many aspects (losses, culture, immigration status, racism, anti-immigrant sentiment, domestic violence) in their acculturation, as well as the lack of support during their settlement. The "lack of support during migration, along with the pressure to assimilate, causes acculturative stress that influences their settlement" (Dalla et al., 2009, p.168).

Connecting the literature with the findings, Blanca shared in her poem and interview, the pain of grieving a variety of losses when leaving Mexico, and how her settlement caused a lot of stress and isolation. She summarizes her grieving in a quote: "Solo los que han emigrado saben lo que duele" / "Only those who have migrated understand how much it hurts." Immigration for 
default is a stressful event in the lives of Latinas. It brings a sense of isolation in Latinas that is often neglected, influencing their settlement and identity. (Casado et al., 2010; Gonzalez; 2005)

In the literature review, some studies highlighted that the stress on Latinos is influenced by familial, economic, social changes, family separation (Ayón et al., 2017; De la Revilla et al., 2010; Perez \& Arnold-Berkovits, 2018). However, the literature review did not present a more profound analysis regarding the impact of cumulative losses, specifically in Latinas immigrants in Canada and its relationship with acculturative stress.

Based on the poems and conversation with the participants, findings showed that migration, regardless if it was by choice or involuntary, can generate stress, anxiety and, on many occasions, maybe traumatic. Those experiences can present a risk factor to the well-being of Latinas

Alinne shared how leaving her "Abuelos" (Grandparents), country, extended family, culture, and language, when she was a child, was a traumatic experience. Then she found herself in a new country, forced to leave her life behind, she felt alone, scared, with anxiety about her future and stress about her new life. Her reality reflects the reality of many immigrants presented in the literature. Studies concluded that migration causes many losses and grief, leading to stress and anxiety (Abbasi, 2015; Dalla et al., 2009; Cleary, Snead, Dietz-Chavez, Rivera, \& Edberg, 2017).

Research shows that the transition of the immigrant leaving everything that was loved and familiar can lead to trauma (Abbasi, 2015). In addition, research states that there is an association between trauma and premigration, during migration, and postmigration experiences in Latinos (Cleary et al., 2017; Perreira, \& Ornelas, 2013;). Moreover, some studies have argued that stress and trauma may affect the well-being of immigrants (Abbasi, 2015; Perreira \& Ornelas, 2013). Under the perspective of LatCrit, some studies have recognized the experiences of Latinas, 
acknowledging the influence of stressors and the impact of migration in their well-being. The experiences of immigrant "women of colour" (Latinas) with assimilation are fragmented due to stressors caused by structures of oppression like discrimination, racism and sexism (Flippen \& Parrado, 2015; Portes \& MacLeod, 1996). Those studies missed focusing on how the cumulation of losses and stressors in Latinas identities dictate their settlement experiences in Canada.

The findings in this study showed that based on the social location of Latinas, the cumulation of losses, stress, and trauma hinder the settlement of Latinas in Canada. In the case of Carla, she described her acculturation and settlement experiences as traumatic. Her migratory grief became complicated when Carla had to faced many challenges (immigration status, lack of English skills, domestic violence) in her settlement process. Carla's stressors were exacerbated by their settlement experiences, causing a risk to her welfare.

The findings in this study showed that it is highly likely that stress and trauma after migration adds to the mourning of losses that come before migration. Those stressors affect the acculturation and settlement of Latinas in Canada.

\section{Cultural Bereavement influences the cultural values of Latinas impacting their settlement}

Another topic that was discussed in the findings was the influence of cultural values in the settlement process of Latinas. The findings in this study argue that for Latinas, their cultural values determine their gender roles interconnecting with a variety of oppressive structures that influence non only their bereavement but their settlement experiences.

Literature under the lens of LatCrit theory discussed findings under a gender analysis that explained how cultural bereavement and systems of oppression influence the migratory journey of Latinas. Some articles in the literature argue that cultural bereavement is triggered by the loss of cultural values, social structures, and self-identity of the immigrant. The articles further argue that 
the effect of cultural bereavement can distress the immigrant. (Eisenbruch, 1991) Another study by Bhugra \& Becker (2005), argues that cultural bereavement influences the process of acculturation in immigrants. Few studies examine how cultural values of Latinos influence their migratory experiences (Hernandez-Truyol, 1997; Solórzano \& Bernal, 2001). There are very few studies than focus specifically on Latina experiences (Perez \& Arnold-Berkovist, 2018; Schoulte 2011;) Although the literature is not vast in this subject, the discussion of the literature aligns with the findings of this study.

The poems written by Alinne, Blanca and Carla, connected with the literature by sharing their experiences on how their cultural values (familismo, marianismo and simpatica) influenced their gender roles and interjected with their cultural bereavement and settlement process. Studies in the literature argue that familismo values loyalty and unity. It is the belief of putting the need of the family before the needs of the individual, it influencing identity and perception of self (Bean et al. 2001; Calzada et al. 2010).

For Latinas, the concept of family includes extended family and friends, where each member of the family learns to make decisions and behave based on pleasing the family (Flake \& Forste, 2006; Gonzalez \& Méndez-Pounds, 2018). The literature connects with the narratives of the participants, through Alinne story, she described in her poem 'The Labyrinth of Pain" how the connection with her family, culture, the language was part of her identity and when she lost them when she immigrated to Canada as a child. The cultural bereavement and migratory grief of Alinne were so profound that they affected not only her settlement but her identity as well. The literature accurately shows that the values and traditions of Latinas are firmly attached to their identity influencing their experiences with migratory grief and cultural bereavement during their settlement. (De Snyder, 1987; Furman et al., 2009). 
The literature argues that the cultural value of Latinas not only dictate their experiences with migratory grief, but they impact their coping mechanisms through their settlement ( Schoulte 2011; Perez \& Berkovist, 2018). The literature connected with the stories of the participants when Blanca shared how she mourned the sense of belonging and closeness that familismo provided to her before her migration. She tried to make connections with the Latino diaspora as a way to recapture the interconnection and closeness. However, those connections lacked the warmth and closeness that Blanca was craving. She realized that Canadian values and traditions now influenced those relationships.

In the case of Carla, she focused on her nuclear family in Canada as a way to helped her to cope with the loss of her extended family. For the three participants, the value of familismo influenced their bereavement and their settlement. The findings in this study regarding familismo indicate that this value influences the attachment of Latinas to their homeland, affecting their acculturation process.

LatCrit tenet of storytelling recognizes that the knowledge of Latinas is socially constructed and political and identifies power disparities in their experiences (Delgado et al., 2013)

The narratives of the participants in this study showed how their cultural values such as familismo, simpatica and marianismo could either support them during their bereavement and their settlement or can hinder their settlement experiences and complicated their grief. Those findings are linked to literature. Hunnicutt (2009) argued that marianismo, simpatica and Familismo values "reflect a dualism, where either those values have a positive influence in the lives of Latinas or are used to exert power and subordinate Latinas through repression" (p.554).

During their interviews, participants highlighted the influence of the value of marianismo in their perception of their roles as mothers and wives. The characteristics of marianismo have a 
duality of both positive and negative behavioural expectations. On one side marianismo highlights the concept of "la mujer buena /the good woman" that is capable and strong; on the other, her exertion of power is limited mainly to the home focusing in the care oh her family (Castillo et al., 2010). Those roles based on the narratives of Blanca and Carla influenced them to self-sacrificed to hold the family together and as wives to submission. Blanca commented on how she felt even more isolated and stressed after she decided to sacrifice her professional career to stay at home. After having her children, Blanca partakes in caretaking duties with the purpose to help the family avoid child care costs. This discussion aligns with the literature about the impact of marianismo in Latinas.

The study of Raffaelli \& Ontai (2004) demonstrated that marianismo could negatively influence Latinas into subordination, reflecting the believes that Latinas must show obedience for the patriarchal family structure (p.290). In other studies, marianismo influences Latinas into selfsilencing to prevent confrontation and to maintain harmony within their relations (Sanchez et al., 2017). Latinas are expected to be deferential to their husbands performing self-sacrificing behaviours to benefit the family structure as an emulation of the virgin Mary (Hubbell, 1993; Mendez-Luck, \& Anthony, 2016). Additionally, the Maria Paradox commands Latina women to prioritize the needs of men over their own needs, reinforcing gender expectation of submission. This paradox may negatively influence Latinas experiences because "connects capable, intelligent, ambitious Latinas to a no-win lifestyle insisting that Latinas live in a world which no longer exists" (Gil \& Vazquez, 1997, p. 273). In another study, Latina women put conformity over conflict first, reducing their opportunities considerably to ask for help and leave an abusive relationship. (Harper 2017). 
The literature relates to the narrative of Carla regarding the influence of marianismo in her marriage. Carla was taught by example from her mother that women must sacrifice for the sake of the family. In despise of being in an abusive relationship, she believed that as a wife, she could demonstrate love to her husband by being all-forgiving and accepting and by prioritizing the needs of her husband at the expense of her own needs and safety.

Some studies in the literature conclude that the cultural value of simpatica inspires Latinas to be polite, respectful, social, outgoing, kind, friendly and caring. In the duality of this value, simpatica influences the roles of Latinas to be submissive, compliant, and not to express confrontation or assertiveness (Carr-Ruffino 1999; Harper 2017; Ortiz, 2018). The simpatica value may influence the migratory grief experiences in Latinas triggering abusive situations against them in their new host country by encouraging them to be caring, benevolent and forgiving even at the risk of their own safety increasing the possibilities of being abused. Simpatica causes that Latina women put conformity over conflict first, reducing their opportunities considerably to ask for help and leave an abusive relationship (Harper 2017). Carla, in her poem, demonstrated how the simpatica value influenced her to be forgiving and to provide care to her husband at her own risk. Simpatica encouraged Latinas to be empathic and to conform by avoiding conflict in order to maintain harmony in the relationship (Castillo et al., 2010). In the case of Alinne, she felt that she had to be compliant and subordinate to the structure of her new family in Canada to fit in. She tried to conform by finding a connection within her family without too much success. Blanca felt restricted to practice her simpatica value during her settlement due to the influence of Canadian culture in the social interaction of Canadians. Blanca had to adjust her level of friendliness and openness because, in Canada, the interactions are more restrictive and colder. 
The finding in this study align with the literature; it has shown that the value of simpatica and marianismo influenced Latinas to be complacent to traditional roles and to subordinate to the dominated culture even in despise of struggles that may harm them. The narrative of Carla connected with the literature when she explained how she felt when she had to care for her husband and be there for him because she was the only person that could unconditionally support him with his mental issues.

Cultural values may have a positive impact on the bereavement and settlement of Latinas. familismo, simpatica and marianismo can exalt the friendliness, kindness, compassion of Latinas as a coping mechanism to their migratory grief. However, the duality of cultural values may have a negative effect on the cultural bereavement and settlement of Latinas in particular, the pressure to place the needs of over their needs to preserve family ties and relationships may hinder their migratory experiences exacerbating their grief. Cultural values may stop being a source of comfort and become an enabler of violence against women. Finally, cultural bereavement influences the interaction of Latinas with their cultural values shaping the perception of themselves in their gender roles and the way they uphold those traditional norms during their migration.

\section{Changes in Identity}

Another important point brought up throughout the findings is that the experiences of Latinas with migratory grief influences their identity during their settlement. Through the lens of LatCrit, this discussion argues that the identities of Latinas are multidimensional. Their identities are influenced by their migration, social factors, values and experiences during their settlement. Hernandez-Truyol, (1997) Furthermore, the identity of Latinas may be influenced by external and internal factors that oppressed them and empower them (Solorzano \& Bernal, 2001). 
Those studies connect with the discussion presented by the participants on how their migratory experiences had shaped their identities. Identity changes were another key factor identified by Carla, Alinne and Blanca during their migration. Carla and Blanca identified influences in their identities as Latinas. Alinne, on the other hand, talked about her identity as Latina dying to be replaced by a Canadian.

Immigrants identities may be changed by the process of acculturation (Gil \& Vega, 1996; Perez \& Arnold-Berkovits, 2018). Some studies in the literature argue that the process of acculturation can have a positive effect on Latino identities by bringing closure to their heritage and culture (Taylor et al., 2012). Changes in identities due to acculturation may help them adapt to stressors and experiences that accompany immigration (Rodriguez, 2000).

Carla's story connects with the discussion. Carla explained how her experiences with migratory grief, domestic violence and single motherhood and as an undocumented immigrant had taken part in influencing her identity. This narrative shows that acculturation may help the culturally bereaved individual to gain a semblance of equilibrium. Bhugra \& Ayonrinde (2004) wrote about how the migratory experiences of the immigrant in addition to the attitudes od the host country towards the immigrant can influence changes in their identities (Bhugra. \& Becker, 2005).

Studies in the review claimed that for Latinos, their grief process and looses associated with migration are often ignored, and if let them unresolved may cause negative effects on their identity (Casado et al. 2010; Gonzalez, 2005). Carolyn Liebler (2017) argues that significant vicissitudes influence changes in the identities of immigrants (Deaux et al., 2018). For Carla, her identity was influenced not only by migratory grief experiences but also by domestic violence, racism and discrimination during her settlement. 
Acoach \& Webb, 2004 discussed that negative perceptions of Latino culture in the host country hinder their identity. Alinne did not have any support during her migratory grief. According to her narratives, the losses overwhelmed her to such a degree that Alinne felt the need to disconnect with the Latina part of herself. Gonzalez (2005) claimed that for Latinos, their grief process and looses associated with migration are often ignored, and if let them unresolved may cause negative effects on their identity (Casado et al. 2010). The literature connected with the discussion when Alinne explained that her migratory grief and losses were so traumatic that her concept of self and identity was lost.

Ferreira (2014) spoke about how immigrants' identities due to extreme causes during migration will assimilate. Immigrants will process assimilation as a coping mechanism to deal with grief and losses. Immigrants will reject their native traditions by replacing them with the culture of the host culture (Bhugra, 2004). The narrative of losing one's identity during assimilation connects with the experiences of Alinne. As Alinne settled in Canada, she felt the need to assimilate into Canadian culture fully and left behind her Latina identity as a coping mechanism to deal with her grief. Her identity was lost during the assimilation process.

A study by Torres (1999) argues that as a coping mechanism, immigrants identities change as a way to maintain their culture while being changed by their new culture. Moreover, Love \& Buriel (2007) claim that Immigrants identities may be shaped by biculturalism (a synthesis of two different languages and cultures that result in a newly shaped third culture. Latinos immigrants may be devolved a bicultural identity as a way to balance living in a dual society of Latino culture in their home environment and the host country culture outside of their environment. (Ferreira, 2014). Blanca named her poem "Doble Identidad/Double Identity" to express the duality that exists 
in her identity. Blanca discussed how her identity conflicted with her cultural values as Mexican and the influence of Canadian values in her life in Canada.

Blanca and Carla spoke how, as their grief process progressed, they began letting in influences of the host country finding common ground where they felt that they would not lose their identities as Latinas. This narrative relates to immigrant experiences with the loss of their homeland and culture. They may discover that as they advance with the process of acculturation, a new sense of belonging occurs (Bhugra \& Ayonrinde, 2004). For Blanca, her identity as Mexicana is no longer affected by integrating Canadian culture; it exalts her identity as Latina.

Most of the articles in the literature regarding Latinos' identities and migration focus on the experiences of Latinos in the United States. However, there are not studies in Canada that focus on Latinas/os identities shaped by grief and experiences due to migration. This discussion presented findings concerning the impact of migratory grief in Latinas identities in Canada. Findings in this study argue that the identities of Latinas are influenced not only by their grief but also by their experiences in their settlement. This discussion illustrates the multidimensions of Latinas identities and the influence of the host culture in their assimilation and acculturation of their identities during their settlement.

Struggle with systems of oppression-No eres bienvenido o eres una carga (Either you are not welcome or you are a burden)

Blanca, Carla, and Alinne recognized and objected in their poetry the systems of oppression that they had experience in Canada, shaping their migratory grief journey. Race as a social construction is one of the principles of LatCrit; it claims that there is not a biological fundament for the construction of categories of race. It further argues that Latinas identities are judged and 
oppressed based on the ethnicity bias that the dominant white group holds over them. (Montoya, 1994; Stefancic, 1997).

Furthermore, this discussion aligns with the Critical Race literature that argues that people of colour (Latinos) during their settlement are taught to recognize the subtleties of microaggression. (Pérez Huber \& Solorzano, 2015) Other studies argue that the experiences of Latinos with discrimination and racism are influenced by their social location (Pérez Huber \& Solorzano, 2015; Solorzano, 1998; Solorzano \& Yosso, 2000). Furthermore, other articles found that racism and discrimination affect the well being of Latinas (Pérez Huber \& Cueva, 2012; Solorzano, 1998) Moreover, discrimination and racism may act as stressors causing the immigrants to feel powerless.

Carla, Blanca and Alinne, narrated how they perceived and framed the different forms of oppression (discrimination, racism, stigma and stereotypes, anti-immigrant sentiment) that they have encountered as against them Latinas immigrants in Canada.

In Alinne's poem; “The Labyrinth of Pain" she described her invisibility as an immigrant; when she arrived in Canada, Alinne felt that she had to assimilate and forget her identity as Latina in order to survive. Another important point brought up throughout the findings is how Latinas confront many systems of oppression when they arrive in Canada that leaves them in a vulnerable position during their grief process. The intersection of experiences of immigration gender inequalities, social marginalization, and cultural bereavement causes an effect in Latinas of being erasure on their own ethnic identity. Gastaldo (2014) explains that a "biographical erasure" is erasure by the dominant culture of the cultural identity of Latinas. This erasuse causes Latinas "to be seen and to feel as permanent a foreigner" by erasing the cultural values, traditions, language 
of Latinas during the process of assimilation in Canada; the dominant culture causes a hinder in the integration on Latinas in Canadian society (p.64).

In the literature, some studies examine structures of oppression among Latinas immigrants in the United States (Gil \& Vega, 1996; Pérez Huber, 2010; Perez \& Arnold-Berkovits, 2018). studies by Pérez Huber (2010) determine that Latinos/as immigrants are a more frequent targeted of racist nativism due to the negative construction of Latino perceptions that exist in the United States. (Pérez Huber \& Solorzano, 2015). Another study argues that being the object of racism as immigrants hinder the settlement of Latinas (Perez \& Arnold-Berkovits, 2018).

Moreover, the study findings argue that the intersection of structures of oppression and immigration may exacerbate the migratory grief of Latinas (Perez \& Arnold-Berkovits, 2018). Those studies related to the narratives of Carla, Alinne and Blanca regarding the impact of migratory grief with systems of oppression during their settlement. However, the shortcomings of these studies are that their emphasis is on Latina immigrants in the United States, ignoring the experiences and stories of Latina immigrants in Canada.

In her poetry, Blanca named the multi-dimension of oppression that she had to confront as a Latina immigrant in Canada. Blanca described how anti-immigrant sentiment and microaggressions are part of her daily interactions with Canadian society. She described how microaggressive comments relating to her native language, cultural values and traditions as Latina are made to her in her daily life.

Blanca brought another important point on racism and stereotypes that exist in social services in Canada. She described in her poem how systemic racism, stigma and discrimination intersect to oppressed her while applying for social services when she was pregnant. The assumption that was made by the service provider about Blanca due to her ethnicity, immigration 
status and gender demonstrated how anti-immigrant sentiment and racism are embedded in social services.

Latinos, due to their colonial stories, bias and stereotypes imposed by the white colonial state, are constantly reminded that they will never be "Canadian enough" to be accepted (Gastaldo, 2014, p.63). In the case of Alinne, despite that she fully acculturated in Canada, she has still been the object of stereotypes around her Latina identity in her daily interactions. She has had to deal with the expectations that people in Canadian society has regarding Latinas. While for Carla, discrimination and racism came with her immigration status but also came invisibility. In her poem, Carla describes the isolation that she felt as an undocumented immigrant who was ignored by the host country community.

The dominant culture puts pressure on immigrants to assimilate. The host culture uses discriminatory tactics targeting immigrants' cultural values and language. However, Latinos hold to their language as a source of strength, regardless of being discriminate by speaking Spanish. Latinos resist to stop being bi- or tri-lingual and instead embrace Spanish as the first language as an effort to resist discrimination (Ayón et al., 2018). For Blanca, Carla and Alinne, the microaggressions and racist attitudes of the host culture regarding Spanish made them hold to their attachment even more. Their native language became a source of comfort for their grief, a resistance tool towards discrimination and a cultural link to pass it to their children.

The experiences of Alinne, Blanca and Carla, demonstrated the normalization of racial micro-aggression in Canadian society towards Latinas. In the findings, there was a significant relationship between the intersection of migratory grief and different forms of racism and discrimination that influence their grief process and assimilation in Canada. The migratory grief of Latinas complicates when they are the target of negatives interactions based on her ethnicity. 
Furthermore, those interactions may influence how Latinas perceive themselves and their assimilation in Canada. Meaning that in Canada, Latinas experiences with migratory grief and structures of oppression as immigrants are typically overlooked. Findings indicate a need to challenge anti-immigrant sentiment and racism toward Latinas through advocacy, research and practice.

\section{Resistance \& Resilience}

Other topics that were discussed in the findings that came up continuously throughout the poems and interviews were the resistance and resilience of Latinas as a copy mechanism to deal with their grief and migratory experiences. In the literature, some articles spoke about resistance and resilience in Latinas. There have been some studies under the lens of LatCrit that argue that immigrants are capable of resisting, challenging and overcoming oppression (Pérez Huber \& Solorzano, 2015). Valdes (1997) argue that Latinos are less likely to assimilate the host country as a way to resist the oppressive supremacy of whiteness. Blanca, Carla and Alinne described in their poems how in despise of have endured losses and adversity during their migration. They have to use resilience as a way to empower themselves during their migratory grief journey.

Latinas resist assimilation as a strategy to attain equality and to gather resilience (Valdes, 1997). Alinne experiences connected to the literature when she shared how in her migratory journey, she has been able to rebound from very traumatic experiences during her migration to Canada. Nevertheless, she has been able to reconnect with her lost identity as a Latina and thrive as a Latina and Canadian. Latinos immigrants have the ability to overcome crisis as a supporting factor for adaptation and, ultimately, healthy survival (Becvar, 2013).

Carranza (2008), in her study, concluded that strategies used by Latinas to overcome oppression are not in tune with dominant Anglo-strategies; however, they are an effective 
protective factor against subordination. Those narratives connected with the discussion when the participants demonstrated through their narratives and poetry multiple ways to resist oppression and to demonstrate resilience in adversity.

Alinne, Blanca and Carla resisted being invisible in Canadian research by participating in this study. Solorzano \& Bernal (2001) argue that LatCrit offers a lens to "talk about transformational resistance in Latinas" (p. 312). For Blanca and Carla, resistance meant having the opportunity to narrate their stories and be heard in their language, in their own way. Alinne talked that resistance for her meant to challenge preconceived narrative notions about Latinas and to present a more accurate reflection of their experiences in Canada.

Alinne, Blanca and Carla have reacted with resilience to multiple sources of oppression in their migratory journey. There have been some studies that argue that immigrants are capable of overcoming oppression (Pérez Huber \& Solorzano, 2015). For Latino families being bilingual and bicultural are important resilience factors. Blanca and Carla talked about the importance of passing traditions to their children while including Canadian influences. Carla spoke about resilience when she shared the importance of writing her poem in English as a way to showcase the bilingual abilities of Latinas. Latinos use bilingualism as a method to resist and as a resilience strategy to preserve positive connections with their culture of origin and the one in their host country (Cabrera \& Padilla, 2004: Becvar, 2013).

Latinas learn how to navigate the norms and values of the dominant culture effectively as well as to maintain their values, language and traditions. The three participants mentioned that keeping ties with their culture and traditions, continue speaking Spanish and pass it to their children; all are mechanics that have been used as protective factors to challenge domination.

(Casado \& Leung, 2001; Gonzalez, 2005; Rando, 1993). 
Finally, the stories of the participants exhibited some parallels associated with the dualprocess model of grief, developed by Stroebe and Schut (2010) This process identifies that grief is messy and multidimensional. Moreover, it recognizes a dualism in the way the bereaved reacts to grief; the oscillation between coping behaviour and avoidance, and the importance of the need of the bereaved to express and control feelings and actions depending on the circumstances (Stroebe at el., 2008; Stroebe and Schut, 2010; Stroebe et al., 2002; Stroebe et al., 2016).

The parallels can be seen in Blanca, Carla and Alinne poetry. The participants narrated the ambivalence of their pain, mourning and losses caused by migratory grief. Their poems and narratives showed the influence of systems of oppression in their grief instead of their grief been centred exclusively on their losses. Secondly, the stories of the participants revealed how, during their settlement, they have dither between coping behaviour and avoidance.

Lastly, this study recognized an ambiguity in the bereavement of Latinas, impacting their experiences during their migration. The poetry presented by Blanca, Carla and Alinne demonstrated the duality of the impact of migratory grief and cultural values in their settlement. Their stories narrated how helpful and detrimental the effects of their cultural values may have on their acculturation. Those effects are the stark difference between the expectation of migration and reality. In the end, the stories of the participants exhibited the longing on their losses. The duality of their migratory grief, the contradictions during their settlement, the impact that immigration and acculturation had on their identity, their efforts to straddle their two worlds trough their cultural values, all fused to create a more complex reality in their settlement.

\section{Limitations}

This study was limited to the type of literature that was available. There was a limitation regarding the access to Canadian literature that was relevant to the study. Literature in the United 
States and Spain, focusing on experiences of Latinos with migratory grief, had to be included to expand and enrich this literature review.

This study understands the limitation based on the sample size of participants. The participants in this study represented a self-selected small group. Three Latinas whom each had great insight based on their migratory grief journey participated in the study. Therefore, while this is an appropriate sample size for a qualitative study, the question remains as to whether the results will be relevant to larger samples. This study understands that the findings do not represent the experiences of all Latinas living in Canada.

Another limitation of the study was the inability to have an in-person interview with the participants to discuss their poems. Due to the COVID-19 guidelines, all in-person interviews were moved to phone interviews as a precaution method. The setting of the interview acted as a limitation of the collection of visual and circumstantial data that could have enriched even more the study.

\section{Impact}

I hope that this study contributes to enabling Social Workers to recognize migratory grief and to gain a better understanding of the impact of cultural bereavement in the lives of immigrants. Also, this author hopes that social workers and service providers advocate challenging the invisibility that exists in the Latino community. Social workers can advocate for change in policies to provide services, resources and programs that will support no only the Latino diaspora but to all the immigrant communities throughout their settlement process and grief.

Migratory grief is real; it is a common denominator shared by the thousands of immigrants arriving in Canada every year. This issue must be further studied in social work, so new programs are developed that incorporate into practice the cultural values of newcomers. Also, service 
providers must be aware and culturally competent of this crucial issue and of the importance of recognizing and acknowledging the migratory grief of immigrants by providing them with emotional support during their settlement journey. Loss and grief related to immigration are a fundamental issue that needs to be studied as many immigrants require services that are culturally tailored to their unique values and customs to supported them through their settlement path in Canada.

Thorough poetry, Latinas stories of migratory grief, cultural bereavement during their settlement process help practice to gain a better understanding of the effects of their grief in their identity. Their stories provide valuable information to researchers regarding Latino experiences, and the findings can guide scholars in understating how migratory grief influence the migration experiences of Latinas

Regardless of the limitations, the study had strengths and furthered our understanding of experiences of Latinas as a population overlooked by Canadian research. The results of this study could assist in the design of culturally effective interventions for Latinos. Future studies should explore the risk and protective factors that intersect with the migratory grief of Latinos, so it will be possible to provide support services that will reduce negative outcomes and enhance resilience.

The phenomenology of migratory grief, cultural bereavement and its effects in the identity and well-being of Latinas, is understudied in Canadian Latin Americans. Presenting the research under the lens of Latin Critical Race theory can help Social Work to gain a better understanding of the Latino diaspora formation in specific on issues of migratory grief and cultural bereavement and the influencing factors in their process of acculturation to Canada.

As this diaspora community settles and grows, so will the need to be represented in academia and the need to do research that disrupts the invisibility of Latinos and bring their 
identities and issues into the Canadian narrative, integrating Latinos into all aspects of the fabric of Canada. Finally, this author hopes that this study will enrich the reader and the public's understanding of migratory grief, promoting a new insight into the impact of grief in the migratory journey of immigrants.

\section{Recommendations}

The recommendations from this study result from the findings and also from the entire process of this research. Firstly, grief has no time frame, and it is as individual as a fingerprint. I invite social workers to reflect on their own understanding of migratory grief. To get familiar with the complexities of grief and loss during migration so they can provide grief support services that support the bereavement of the immigrants.

One recommendation is for social workers to include in their practice a companionship model that recognizes and validate the losses of immigrants within a culturally safe space. Through that model, immigrants are allowed to not only recognize but feel their grief. So, they can start the process of honouring their losses by permitting themselves to grieve and to connect with their cultural values as a source of comfort while they comprehend the impact of their losses in their new life in Canada.

Secondly, I recommend decolonizing migratory grief in research. One of the strengths of this qualitative study is the anti-oppressive, anti-racist, decolonial approach to include postmodern frameworks to guide this research. The incorporation of art-based poetry and narrative approaches to honour Latinas tradition of storytelling and the principles of LatCrit theory center Latina voices to create knowledge and to disrupt rigid Anglo-western hierarchies regarding who should be creating knowledge. 
Decolonizing the life stories of immigrants help to expand discussions of race, gender in a way that increases a better of understanding of their migratory grief experiences. According to Allan (2006), social work research in North America is "western, Anglo and white-centric," so it is the grief model (as cited in Sakamoto, 2007 p.111). The western ideology of grief is rooted in colonialism and white supremacy ideologies that have created a grief hierarchy where acceptance, tolerance and support to the bereaved pain and loss is a luxury for minorities. Decolonizing grief in research means dismantling dominant discourses that marginalize migratory grief. According to Haig-Brown (2012), what hinders that understanding is the lack of willingness to listen to each other and the avoidance of sharing stories of colonialization (p.88).

Canadian research must dismantle dominant migratory grief discourses through an antioppressive practice that includes analysis and transformation of power relations (Healy 2005; Glaser, 2017). Researchers wishing to counteract dominant discourses should challenge those ideologies and offer methodologies and practices that embrace holistic approaches that analyze the complexity of migratory grief and the many layers of pain, loss and sorrow that encompasses. Furthermore, Canadian researchers should focus on the emotional, ethnical, spiritual, and cultural parts of migratory grief that aids the bereaved to search for meaning from their losses and to ease their settlement in a new country.

Thirdly, a final recommendation is to incorporate ethics of care in social work. One way to challenge the western grief model within social work is to recognize and integrate ethics of care in social work regarding migration and grief support. Ethics of care is a feminist approach, a moral theory that focuses on meeting the needs of the others for whom we take responsibility (Held, 2006). Noddings (2010) argues that "care is an act of receptive attention" (p.35). It mandates to 
care for the most vulnerable. It "requires empathy, compassion, and motivation and for that care to be accepted" (Noddings, 2010, p.45).

Ethics of care are compatible with social work values of advocacy, social justice and dignity. Ethics of care takes one step further in caring. It promotes interconnectedness by given importance to human relationships with integrity and competence. Incorporating ethics of care can make a significant contribution by not only revitalizing the model of care for social work but by providing a critical framework for moving beyond the current approaches of managerialism on social work. Thus, care involves and becomes more than a simple issue. Care "becomes political and intimately related to breaking oppressive structures of class, gender, ability, and race" (Meagher, \& Parton, 2004, p.22).

Due to the lack of Care Ethics, migratory grief is invisible in a societal and governmental level. Canadian society and government have failed to validate the migratory grief experiences of immigrants. Immigrants arriving in Canada become a percentage, and as a statistic, their experience of migration is seen as something distant, a notion of otherness (Held, 2005).

Through ethics of care, social work can advocate and fight for social justice for immigrants within a broad political and social context. Social work through practice and research can disrupt the institutionalized invisibility of migratory grief in Canada.

Social workers can bring awareness of the incapacity of the societal level and the government level and their lack of moral responsibility (Tronto, 2010). Social work through the use of ethics of care in their practice can help in transforming those structures oppression that until today have intersected to marginalized Latinas immigrants

Finally, ethics of care can support social workers' self-understanding as moral agents in caring relationships with service users (Meagher, \& Parton, 2004). Social workers using ethics of 
care can approach immigrants with a deep awareness and empathy for their challenges and experiences with migratory grief. Social workers can honour the caring relationship, that they established with their service users by creating a practice where grief is encouraged and supported, by letting the "bereaved to take control of their grief and to lead the way in their grief journey" (Louie, 2013 p.4).

\section{Conclusion}

The experiences of grief and losses due to migration are a universal reality for immigrants. However, Latinas go through the process of grieving in their own unique ways. Migratory grief influences their migratory journey based on the intersections of their gender, social locations, cultural values and structures of oppression, shaping their identity and settlement in Canada.

The stories of the participants showed that grief is complex and underestimated. Exists a connection between their mourning, social location, cultural values and structures of oppression that determine their grief responses to their settlement.

Migratory grief needs to be given more attention in research to be able to better understand its impact on the lives of immigrants during and after migration. Based on the findings in this study, the migratory grief on Latinas complicates when they are the target of negatives interactions based on her ethnicity. Furthermore, those interactions impact how Latinas perceive themselves and their assimilation in Canada. Meaning that Latinas experiences with migratory grief and structures of oppression as immigrants are typically overlooked in Canada.

The purpose of this study is fulfilled, as it is to contribute to the literature and to commence the creation of knowledge that invites the readers to gain a better perspective of the impact of migratory grief in Latinas. The findings and discussion on this study presented the knowledge 
generated from Latinas that have been as a race subordinated in Canadian culture and excluded in Canadian social work research and practice.

This study has been very important to me. I wanted to contribute to social work research because literature in Canada about migratory grief in Latinos is non-existent. I noticed during my migratory grief journey and during my practice as a social worker that the Latino diaspora is not represented in research and practice.

As an immigrant, I yearned from migratory grief support services that were culturally aware and safe. As a social worker providing grief support and settlement services, I noticed the gap that exists in services for Latinos and the need of the community to access culturally safe grief support services. As a researcher, I wanted to see in literature Latino studies that I noticed are incipient in Canadian social work and to empower the representation of women who are transnational ambassadors in Canadian literature.

A strength of this study is the presentation of the counternarratives of Latinas. Through their poems as an exploration method, the reader will have a better understanding of the experiences of Latinas during their migratory grief journey and their connections with oppressive systems (racism, sexism, discrimination, anti-immigrant sentiment). This research recognizes the limits of understanding the complexities of racial, the gender of the experiences in all Latinas. The complexity of grief and experiences due to migration has been understudied in Canada.

Under the lens of LatCrit advocating for the creation and advancement not only of theory but of practice (Valdes, 1997). This material aimed to bring social change by presenting Latinas narratives with migratory grief to centre Latino migration discourses in research and academia. Furthermore, because social transformation is a key function in social work, this research aimed 
to foster social justice by bringing to light the unique challenges that Latino diaspora encounter in Canada.

The stories of Blanca, Alinne and Carla provided to this research insight into the impact and effects of grief during the migratory journey into Canada. The poetry and narratives of the participants are raw, powerful, personal, shaped by their strength and inspired by their courage. Their words in their poems are the strongest means of pouring their narratives of grief into a message of resilience to share with the world.

Finally, this research concludes with a quote from the painter Frida Kahlo (1952) that so brilliantly expressed the complexity of the experiences of Latinas and their ability to resist oppression and to overcome challenges.

'No reniego de mi naturaleza, no reniego de mis elecciones, de todos modos, he sido una afortunada. Muchas veces en el dolor se encuentran los placeres más profundos, las verdades más complejas, la felicidad más certera... / [English] I don't deny my nature, I don't deny my choices, anyway, I've been a lucky one. Many times, in pain you find the deepest pleasures, the most complex truths, the most certain happiness." - Frida Kahlo 


\section{APPENDIX A- RECRUITMENT EMAIL ENGLISH \& SPANISH}

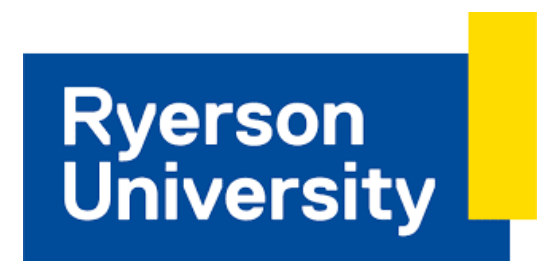

\section{$\underline{\text { Recruitment Email }}$}

Subject: Research Study Participation regarding migratory grief in Latinas

Hello, my name is Covy Blanco. I am a graduate student of the Master of Social Work program at Ryerson University. I am doing a study for my master's research project, and my supervisor name is Dr. Ken Moffatt of the Faculty of Social Work at Ryerson University.

I am contacting you to see if you might be interested in participating in my research study regarding the impact of grief migration on Latinas in Canada. The purpose of the study is to learn more about the overall effects of migratory grief and loss in the well-being and identity of Latinas. The focus of this study is to gain a better understanding of the losses experienced by Latina women due to migration and how those losses have influenced their life in Canada.

\section{To participate you need:}

- To identify as a woman

- Be 18 years old and older

- To identify as Latina

- To have immigrated to Canada from any country from Latin America and resided in Canada for at least a year.

- You enjoy artistic expression, like using poetry as a way to express yourself.

Participation in this study is confidential and voluntary. You are also able to withdraw from participating at any time.

\section{If you agree to volunteer, you will be asked:}

- To commit to participating in two individual phone interviews of one hour. Those interviews will be divided into one initial interview and one final interview (one interview per week) regarding your lived experiences with grief and loss as an immigrant in Canada. 
- After the initial interview, you will be asked to contribute with a poem describing your experiences with migration, grief and loss as Latina. The poem will be presented in the final interview. (You don't have to be a poet or an artist)

- If you don't feel comfortable with creating a poem, you can choose to write a poetic expression that expresses the story of migratory grief and its impact on your life and what it has meant to you as a Latina immigrant.

\section{Interviews can be conducted in Spanish or English}

If you would like to participate in this study or have any further questions or concerns, please send your response by email at cblancom@ryerson.ca

In light of the COVID-19 outbreak, and following the Ryerson Research Ethics Board (REB) advice, this project has been modified to accommodate safety protocols to protect participants and researchers. To prevent risks, all personal contact and interviews between participant and researcher will be modified using social distance guidelines to prevent infection and to safeguard the well-being of participants and researchers.

This research study has been reviewed by the Ryerson Research Ethics Board (REB 2020-077)

Thank you for your time, Covy Blanco BSW, SSW 


\section{Ryerson}

University

\section{Spanish Template /Borrador en Espanol}

\section{Correo electrónico de reclutamiento}

\section{Asunto: Participación en un estudio de investigación sobre el duelo migratorio en Latinas}

Hola, mi nombre es Covy Blanco, soy estudiante de postgrado de la Maestría de Trabajo Social en la Universidad de Ryerson. Estoy haciendo un proyecto de investigación como parte de la Maestría de Trabajo Social. El nombre de mi supervisor es Dr. Ken Moffatt, profesor adjunto de la Facultad de Trabajo Social en la Universidad de Ryerson.

Me pongo en contacto con usted para ver si podría estar interesada en participar en mi estudio de investigación sobre el impacto del duelo cultural y migratorio en las mujeres Latinas en Canadá. El objetivo del estudio es conocer los efectos generales del duelo y la pérdida migratoria en el bienestar y la identidad de las mujeres Latinas. El propósito de este estudio es aprender más sobre sus experiencias con las pérdidas que tienen que sufrir las mujeres Latinas desde que dejan su país de origen y cómo ese duelo y perdidas han influenciado en su vida en Canadá.

\section{$\underline{\text { Requerimientos para participar: }}$}

- Identificarse como mujer y tener más de 18 años de edad.

- Identificarse como Latina

- Haber emigrado a Canadá desde cualquier país de América Latina

- Estar residiendo en Canadá durante al menos un año

- Gusto por actividades artísticas como el uso de poemas como forma de expresión La participación en este estudio es confidencial y voluntaria. También puede retirarse de participar en cualquier momento.

\section{$\underline{\text { Si acepta ser voluntario: }}$}

- Se le pedirá que se comprometa a participar en dos entrevistas telefónicas individuales de una hora. Esas entrevistas se dividirán en una entrevista inicial y una entrevista final (una entrevista por semana) con respecto a sus experiencias vividas con el duelo y la pérdida como emigrante en Canadá.

- Después de la entrevista inicial, se le pedirá que contribuya con un poema que describa sus experiencias con la migración, el dolor y la pérdida como emigrante Latina, el poema 
será presentado para analizarlo en la última entrevista. (No tienes que ser usted poeta o artista para crear un pensamiento poético)

- Si no se siente cómoda creando un poema, puede elegir escribir una expresión poética que exprese la historia del dolor migratorio y su impacto en su vida y lo que ha significado para usted como inmigrante latina.

\section{Las entrevistas pueden realizarse en español o inglés.}

Si desea participar en este estudio o si tiene más preguntas o inquietudes, por favor, envíe su respuesta por correo electrónico: cblancom@ryerson.ca

Debido al brote de COVID-19, y siguiendo el consejo de la Junta de Ética de Investigación de la Universidad de Ryerson (REB), este proyecto se ha modificado para acomodar protocolos de seguridad para proteger a los participantes e investigadores. Para evitar riesgos, todos los contactos personales y las entrevistas entre el participante y el investigador se modificarán utilizando pautas de distancia social con

el fin de prevenir la infección y salvaguardar el bienestar de los participantes y los investigadores.

Este estudio de investigación ha sido revisado por la Junta de Ética de Investigación de Ryerson. (REB 2020-077)

Gracias por tu tiempo,

Covy Blanco BSW, SSW 


\section{APPENDIX B - CONSENT AGREEMENT GOOGLE FORM ENGLISH}

\section{Ryerson University}

\section{Consent Agreement}

You are being invited to participate in a research study. Please read this consent form so that you understand what your participation will involve. Before you consent to participate, please ask any questions to be sure you understand what your participation will involve.

In light of the COVID-19 outbreak, and following the Ryerson Research Ethics Board (REB) advice, this project has been modified to accommodate safety protocols to protect participants and researchers. To prevent risk all personal contact and interviews between participant and researcher will be modified using social distance guidelines with the purpose of preventing infection and to safeguard the well-being of participants and researchers.

\section{De su propia voz, el impacto del duelo cultual y luto migratorio en Latinas viviendo en Canadá. \\ (In their own voices, the impact of cultural bereavement and grief migration on Latinas in Canada)}

\section{INVESTIGATORS}

This research study is being conducted by Covadonga Blanco BSW, SSW, a Master of Social Work Student at Ryerson University, under the supervision of Dr. Ken Moffatt professor of the Faculty of Social Work and Jack Layton Chair of Social Justice at Ryerson University.

If you have any questions or concerns about the research, please feel free to contact the principal investigator Covadonga Blanco, BSW, SSW email at cblancom@ryerson.ca or with her supervisor Dr. Ken Moffatt PDH, email at kmoffatt@ ryerson.ca

\section{PURPOSE OF THE STUDY}

The objective of this study is to learn more about the effects of migratory grief and cultural bereavement in the identity and well-being of Latinas Immigrants. The research study will focus in understanding the migratory experiences of Latina women in Canada and how their unique cultural values have influenced their grief and identity You are being invited to take part in this research because we feel that your experiences can contribute to a better understanding of how Latina immigrants deal with the grief and the losses that come with their migration to Canada. 
Furthermore, those experiences can contribute to generate knowledge regarding the of migratory grief and cultural bereavement in the Latin America diaspora population.

The number of participants being recruited/signed up for this study includes three people, using the following requirements:

- Participant identifies as female

- The participant is 18 years old and older

- The participant has immigrated to Canada from any country from Latin America

- The participant has resided in Canada for at least a year

- The Participant must enjoy artistic expressions like using poems or written poetic expressions as a way to express herself.

- Able to commit to participate in two individual phone interviews of one hour and to contribute with a poem describing her experiences with migration, grief and loss as Latina.

The poem will be presented in the final interview. (You don't have to be a poet or an artist)

If you don't feel comfortable with creating a poem, you can choose to write a poetic expression that expresses the story of migratory grief and its impact on your life and what has meant to you as a Latina immigrant.

This research is being done by a graduate student in the Master of Social Work program so that the results will contribute to the master research project of the principal investigator as a requirement of completion of her graduate studies in Social Work.

\section{WHAT YOU WILL BE ASKED TO DO [OR] WHAT PARTICIPATION MEANS}

If you decide to participate and volunteer in this study, you will be required to be in this study for two weeks, during that time, you will be asked to do the following things:

Complete digital consent by submitting it on the google consent form. The link to access the consent form will be sent to you by email, prior to the 1st phone interview. In case that option is not possible you can provide consent through audio recording during the beginning of the 1st phone interview. While the study is in progress the consent forms will be stored online on the Ryerson Google Shared Drive

1. You will be asked to have two phone interviews with the principal investigator:

- During the first week one initial appointment of 1 hour long

- During the second week, a final interview of 1 hour long approx. 
2. You will be asked in your own time at home to invest between 1-2 hrs. of your own time to complete your poem.

- Between the first week interview and the second-week final interview, you will be expected to create your poem. (You don't have to be a poet or an artist)

- If you don't feel comfortable with creating a poem, you can choose to write a poetic expression that expresses the story of migratory grief and its impact on your life and what has meant to you as a Latina immigrant.

All forms and documentation for participants will be presented in Spanish and English to prevent hardship to participants in case they are not fluent in English or in the case they feel more comfortable speaking their native language.

\section{Week 1- One initial phone interview session of 1 hour.}

A phone interview will be scheduled, and it will be divided into the following parts:

1. Introduction and Orientation of the research study and principal investigator

2. Information about rights as a participant, potential risks and benefits of participation.

3. Any clarification regarding procedures, expectations, and consent will be explained.

Interviews can be conducted in Spanish or English, depending on what language you will feel more comfortable.

During the phone interview:

1. You will be asked to commit and to create a poem or written artistic expression during the second week in your leisure time at home.

2. You will be informed of the procedure, expectation and dateline of the poem that you will create.

3. You will be given a week to complete your poem or artistic expression on your own time during the following week. You will be expected to send the poem as an email attachment to me one day before the final phone interview.

4. The Final interview will be scheduled during the following week, and you will be expected to have the poem ready and send it as an email attachment by that time.

5. You will be expected to write the poem and email it to the investigator so it can be ready to be discussed and analyzed in the final interview. You will need to leave a copy of your poem to be included in the research findings.

Note: If you do not wish to answer any of the questions during the interview or to continue your participation, you may say so, and I will move on to the next question or will stop the session. 


\section{Between Week 1 \& Week 2-To create a Poem}

You will be asked to commit to creating a poem expressing your unique experiences with migratory grief and its effects on your identity.

\section{During the second week:}

1. In your free time, at your own leisure, you will be asked to reflect on your experiences with migratory grief as a Latina immigrant and to create a poem describing your experiences with migration, grief, loss and their effects on your well-being as a Latina woman.

2. Your poetic expression can be written in Spanish or English depending on what language you feel more comfortable in expressing your experiences

3. You will be expected to complete your poetic expression on time before the final appointment and to send the poem as an email attachment to me one day before our final interview for discussion and analysis.

\section{Week 3- Final Phone Interview/Presentation of Poem}

The purpose of the final interview is for you to present your poem for discussion and analysis.

\section{During the final interview:}

1. You will be expected to finalize the poem and to send the poem as an email attachment to me one day before the final interview.

2. You will be asked to read your poem and to talk more in detail about it, to analyze it (e.g. how did you feel about writing it.

A copy of your poem will remain with the Principal Investigator for the purpose of analyzing it and using it as part of the investigation. Your poem will be included in the findings of this research as a requirement of completion of the principal investigator's graduate studies in Social Work. You have the right to keep the original copy of your poem for your records.

If the poem is presented in Spanish, will be translated at English by the principal investigators to present findings. A copy of the translation of your poem will be given to you for your records.

\section{What kind of study and where will it be?}

The research study will be in the form of a qualitative study. This study is used when the topic is almost unknown, or when the researcher wants to have a better perspective of a person's experience (Faulkner \& Faulkner, 2016). The study will be done through phone interview style. The location of where the research will be done will be in a private closed room that allows for confidentiality and that meets your needs. You will be interviewed a total of two times, Monday 
to Saturday depending on your availability, the interviews will be 1 hour. You will be asked questions related to your experiences.

Interview questions will be guided by your responses but will follow an interview guide. For example:

1. Questions will be asked regarding clarification of any subject that you talk about in your artistic expression (e.g., In your poem you talk about... [xxx]?

2. The interviewer will ask you questions to learn more about a specific topic that you talk about in your poem (e.g. migratory grief; How have you dealt with your grief? or What cultural values and traditions have influenced your experience with migratory grief in Canada as an immigrant?)

\section{DEMOGRAPHIC COLLECTION}

Due to the nature of the research project, the following demographic data will be collected during the first interview with your consent:
a) Name
b) Age
c) Gender
d) Ethnicity

Information collected from you will be:

- What is your Name?

- $\quad$ Are you 18 or over in age?

- What are your gender and ethnicity?

- What is your email address/ and or phone number?

\section{FINDINGS}

\section{Will the research findings be available?}

The research findings will be available through a link to the Ryerson Digital Repository.

The Digital Repository has been created by Ryerson University as a space to collect, preserve and provide online access to research created by the Ryerson community. All MRP's including my MRP will be uploaded to the digital Repository after completion so that you can get the results on your own time.

After the MRP is uploaded, you can access the Ryerson Digital Repository through this link:

\section{https://digital.library.ryerson.ca/}


Principal Investigator will be available for any questions that you have during your participation and after the findings are presented The poetic expression will be translated at English by principal investigators to present findings if needed.

\section{POTENTIAL BENEFITS}

I cannot guarantee, however, that you will receive any benefits from participating in this study. However, one potential benefit of this study is that it will raise awareness in the Canadian society of the losses that immigrants faced and the influence of their grief journey in their settlement process. Another benefit is that findings on this research project can guide Social Work and scholars in understating the Latino diaspora in specific on issues of migratory grief and cultural bereavement and the influencing factors that contribute to their acculturation in Canada.

Lastly, the findings will present a better understanding of the unique experiences and challenges that Latin women faced when immigrating, those findings can help to inform practices and services tailored to Latina women.

\section{WHAT ARE THE POTENTIAL RISKS TO YOU AS A PARTICIPANT?}

Due to the personal nature of sharing your personal experiences of loss and grief of leaving your home country and migrating to Canada, there is a risk that during the interviews, or during the time that it takes to write the poem or poetic thought you will reflect and remember some unpleasant memories.

At any moment that you feel uncomfortable or you do not wish to answer any of the questions during the interviews, you may say so and the interviewer will move on to the next question or point in the poem or artistic thought analysis.

This topic is about your story so if at any time it causes psychological risks such as anxiety or emotional distress you or me (the researcher) may decide to temporarily stop the interview and/or study or permanently end the study.

Emotional support and referral services will be available during the interview if interviews create any undue stress to you. A list of social services in your community that offer emotional and immigration support in Spanish and English will be given to you in case you need additional support at home or after the study. Before and after the phone interview process, I will send through email a list of support services in English and Spanish in your community. 
Emotional support will be provided by phone. The principal investigator is a grief support facilitator that will be able to offer you individual support during the session if needed and requested. Therefore, a relaxing, grounding exercise will be done as the final step of their interview (e.g.,5 min closing mediation), this mindfulness therapy has been proved in grief support to ground participants and to reduce stress.

If you share any information during the interviews that can potentially be a threat to you or anyone else such as to harm yourself or others, I have a professional duty to report the information to legal authorities. I will make sure that you have a different name in the research study to protect your personal identity.

\section{CONFIDENTIALITY}

All data will be stored on Ryerson Google Shared Drive. The poetry (poems or poetic expressions) will be safe in the Ryerson google share drive so that they can be included in the MRP. The poems will have no identifying information, pseudonyms will be given and assigned to each participant. The entire interviews will be audio-recorded. The raw audio recordings will be deleted following transcription and verification. After the finalization of the phone interviews, the poems, and audio recordings will go on the computer and will be saved and stored on the Ryerson Google Shared Drive, the drive minimizes the risk of data being accessed by unauthorized individuals because it is secure and all information is encrypted. All data collected before and during the interview process will be kept confidential

The data will be stored for a period of one year and it will be available to participants before the data analysis stage. The data for the transcripts will be available to participants for review/edit until May 30,2020, before the research project moves to the data analysis stage. If after that date the participants do not provide input, it will be assumed that participants are satisfied with the transcripts as they are and the researcher will proceed to the data analysis phase. Transcripts will be stored for a period of 1 year. Transcripts will be sent to participants through email with an attachment to a file in the Ryerson Google Shared Drive that is password protected.

You have the right to review/edit the recordings until May 30, 2020, before the data analysis stage. However, if any of the information provided can potentially be a threat to the participants or anyone. I, as the principal investigator, have a professional duty to report the information to legal authorities if necessary.

\section{INCENTIVES FOR PARTICIPATION:}

No incentives will be offered for your participation. 


\section{COSTS TO PARTICIPATION:}

There are some no costs associated with your participation.

\section{VOLUNTARY PARTICIPATION AND WITHDRAWAL}

Participation in this study is completely voluntary. You can choose whether to be in this study or not. If any question makes you uncomfortable, you can skip that question. You may also choose to not have your data included in the study.

Your choice of whether or not to participate will not influence your future relations with Ryerson University or the investigators Covadonga Blanco (principal investigator) and Ken Moffatt (supervisor)involved in the research.

In case you decide not to do the poem your participation may be terminated without your consent. Due to the nature of this project a poetic expression is necessary to inform this investigation, your poetic expression will contribute to advising this project, without a poetic expression this project may not be possible.

\section{QUESTIONS ABOUT THE STUDY}

If you have any questions about the research now, please ask. If you have questions later about the research, you may contact:

\begin{tabular}{|l|c|c|}
\hline \multicolumn{1}{|c|}{ Name } & Email & Position \\
\hline 1.Covadonga Blanco BSW, SSW & cblancom@ @yerson.ca & $\begin{array}{c}\text { Principal } \\
\text { investigator }\end{array}$ \\
\hline 2.Dr. Ken Moffatt PhD & kmoffatt@ @ryerson.ca & Supervisor \\
\hline
\end{tabular}

This study has been reviewed by the Ryerson University Research Ethics Board. If you have questions regarding your rights as a participant in this study please contact:

Research Ethics Board

c/o Office of the Vice President, Research and Innovation

$$
\begin{gathered}
\text { Ryerson University } \\
\text { 350 Victoria Street } \\
\text { Toronto, ON M5B 2K3 } \\
\text { 416-979-5042 } \\
\text { rebchair@ryerson.ca }
\end{gathered}
$$




\section{De su propia voz, el impacto del duelo cultual y luto migratorio en Latinas viviendo en Canadá. \\ (In their own voices, the impact of cultural bereavement and grief migration on Latinas in Canada)}

\section{CONFIRMATION OF AGREEMENT}

In the checkbox below, you will have options to select whether or not you want to participate in this study.

By selecting the "YES" box in the checkbox below and writing your full name, you indicate that you have read the information in this agreement and have had the opportunity to ask any questions you have about the study.

By selecting the "YES" box in the checkbox below and writing your full name, you indicate that you agree to participate in the study and that you have been informed that you can change your mind and withdraw your consent to participate at any time.

Selecting the "YES" box and writing your full name in the checkboxes below, indicates that you have been given a copy of this agreement. You have also been informed that by signing this consent agreement you are not giving up any of your legal rights.

Do you accept to participate in this study?

$\bigcirc$ Yes, I agree

No, I do not agree

** By selecting the "YES" checkbox you are signing this Confirmation Agreement electronically

Full name:
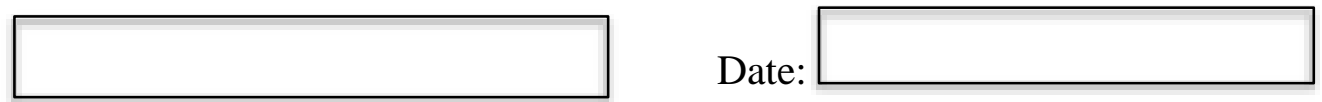

**By typing your name and selecting the "YES" check box you are signing this Confirmation Agreement electronically

\section{Declaration}

I confirm that I was given an opportunity to ask questions about the study, and all the questions have been answered correctly and to the best of the ability of the Principal Investigator.

Yes, I agree

No, I do not agree

I confirm that I have not been coerced into giving consent and that my consent has been given freely and voluntarily.

$\bigcirc$ Yes, I agree

No, I do not agree 


\section{Audio-Record Consent}

I agree to be audio-recorded for the purposes of this study. I understand how these recordings will be stored and destroyed.

Yes, I agree

$\bigcirc$ No, I do not agree

**By selecting the "YES" checkbox you are agreeing to be audiotaped in this study.

I confirm that I have not been coerced into giving consent and that my consent has been given

OYes, I agree

No, I do not agree

\section{Download Consent Form}

Thank you for agreeing to participate in this study.

The Consent Agreement is available in Spanish and English for you to download and keep for your records.

If you wish to obtain a copy of the agreement, click on the link below in the corresponding language to access the Consent Form to download it.

English:

Spanish:

\section{https://drive.google.com/file/english}

https://drive.google.com/file/spanish

\section{Participation Declined}

You have elected no to participate; you can click the submit or simple close your browser 


\section{APPENDIX C - CONSENT GOOGLE FORM IN SPANISH}

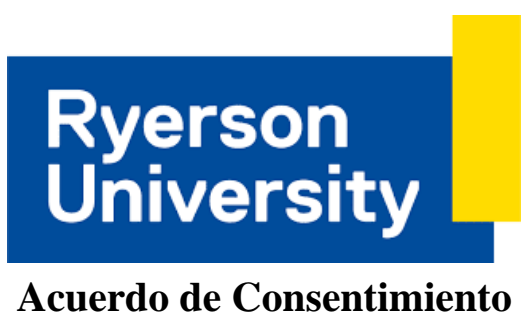

Estás siendo invitado a participar en un estudio de investigación. Lea este formulario de consentimiento para comprender lo que implicará su participación. Antes de dar su consentimiento para participar, haga cualquier pregunta para asegurarse de comprender lo que implicará su participación.

Debido al brote de COVID-19, y siguiendo el consejo de la Junta de Ética de Investigación de la Universidad de Ryerson (REB), este proyecto se ha modificado para acomodar protocolos de seguridad para proteger a los participantes e investigadores. Para evitar riesgos, todos los contactos personales y las entrevistas entre el participante y el investigador se modificarán utilizando pautas de distancia social con el fin de prevenir la infección y salvaguardar el bienestar de los participantes y los investigadores

\section{De su propia voz, el impacto del duelo cultural y luto migratorio en Latinas viviendo en Canadá. \\ (In their own voices, the impact of cultural bereavement and grief migration on Latinas in Canada)}

\section{INVESTIGADORES:}

Este estudio de investigación está siendo realizado por Covadonga Blanco BSW, SSW, estudiante de maestría en trabajo social en la Universidad de Ryerson bajo la supervisión de Ken Moffatt, profesor de la Facultad de Trabajo Social y Jack Layton, Presidente de Justicia Social en la Universidad de Ryerson.

Si tiene alguna pregunta o inquietud sobre la investigación, no dude en comunicarse con el investigador principal Covadonga Blanco al correo electrónico: cblancom@ryerson.ca Dr. Ken Moffatt PHD al correo electrónico kmoffatt@ryerson.ca

\section{PROPOSITO DEL ESTUDIO:}

El objetivo de este estudio es aprender más sobre los efectos del duelo migratorio y el duelo cultural en la identidad y el bienestar de los inmigrantes Latinos. Usted esta invitada a participar en esta investigación porque creemos que sus experiencias al lidiar con el dolor y las pérdidas que 
surgen al inmigrar a Canadá como inmigrante Latina. Estas experiencias pueden contribuir mucho a nuestra comprensión y conocimiento de cómo el dolor migratorio y el duelo cultural es experimentado entre la comunidad Latina específicamente en sus mujeres.

El número de participantes reclutados / inscritos para este estudio incluye a tres personas, utilizando los siguientes requisitos:

- La participante se identifica como femenino

- La participante es mayor de 18 años.

- La participante ha emigrado a Canadá desde cualquier país de América Latina.

- La participante ha residido en Canadá durante al menos un año.

- La participante debe disfrutar de expresiones artísticas como el uso de poemas o expresiones poéticas escritas como una forma de expresarse.

- La participante debe de ser capaz de comprometerse a participar en dos entrevistas telefónicas individuales de una hora y contribuir con un poema que describe sus experiencias con la migración, el dolor y la pérdida como latina.

El poema se presentará en la entrevista final. (No tienes que ser poeta o artista para participar)

Si usted no se siente cómoda creando un poema, puede optar por escribir una expresión poética que exprese la historia del dolor migratorio y su impacto en su vida y lo que ha significado para usted como inmigrante latina.

Esta investigación está siendo realizada por un estudiante de posgrado en el programa de Maestría en Trabajo Social para que los resultados contribuyan al proyecto de investigación de maestría del investigador principal como requisito para completar sus estudios de posgrado en Trabajo Social.

\section{QUE ES LO QUE SE LE PEDIRA QUE HAGA [ O] QUE SIGNIFICA QUE PARTICIPE:}

Si decide participar y ser voluntaria en este estudio, se le pedirá que participe en este estudio durante dos semanas, durante ese tiempo se le pedirá que haga lo siguiente:

1. Complete el consentimiento digital en el formulario de consentimiento en el Google file.

El enlace para acceder al formulario de consentimiento se le enviará por correo electrónico antes de la primera entrevista telefónica. En caso de que esa opción no sea posible, puede dar usted su consentimiento mediante la grabación de audio al comienzo de la primera entrevista telefónica. Mientras el estudio esté en curso, los formularios de consentimiento se almacenarán en línea en la unidad compartida de Google de Ryerson (Google Share Drive)

2. Complete el consentimiento informado por escrito y envíelo por correo electrónico antes de que se puedan realizar entrevistas telefónicas. 
3. Se le pedirá que tenga dos entrevistas telefónicas con el investigador principal:

- Durante la primera semana una cita inicial de 1 hora de duración

- Durante la segunda semana una entrevista final de 1 hora de duración aprox.

4. Se le pedirá en su propio tiempo, en casa, que invierta entre 1-2 horas. de tu propio tiempo para completar tu poema.

- Entre la entrevista de la primera semana y la entrevista final de la segunda semana, se espera que crees tú poema. (No tienes que ser poeta o artista)

- Si no se siente cómoda creando un poema, puede optar por escribir una expresión poética que exprese la historia del dolor migratorio y su impacto en su vida y lo que ha significado para usted como inmigrante latina.

Todos los formularios y la documentación para los participantes se presentarán en español e inglés con el propósito de evitar dificultades a los participantes en caso de que no dominen el inglés o en el caso de que se sientan más cómodos hablando su idioma nativo.

Semana 1- Una sesión de entrevista inicial de 1 hora.

Se programará una entrevista telefónica y se dividirá en las siguientes partes:

- Introducción y orientación del estudio de investigación e investigador principal.

- Información sobre derechos como participante, riesgos potenciales y beneficios de la participación.

- Cualquier aclaración con respecto a los procedimientos, expectativas y consentimiento será explicada.

Las entrevistas se pueden realizar en español o inglés, según el idioma con el que se sienta usted más cómoda.

Durante la entrevista telefónica:

1. Se le pedirá que se comprometa y cree un poema o una expresión artística escrita durante la segunda semana en su tiempo libre en casa.

2. Se le informará sobre el procedimiento, las expectativas y la fecha del poema que creará.

3. Se le dará una semana para completar su poema o expresión artística en su propio tiempo durante la semana siguiente. Se espera que me envíe el poema como un archivo adjunto por correo electrónico un día antes de la entrevista telefónica final.

4. La entrevista final se programará durante la semana siguiente y se espera que tenga el poema listo y lo envíe como un archivo adjunto de correo electrónico para ese momento.

5. Se espera que usted escriba el poema y lo envíe por correo electrónico al investigador para que esté listo para ser discutido y analizado en la entrevista final. Deberá dejar una 
copia de su poema al investigador para que se incluya en los resultados de la investigación.

Nota: Si no desea responder ninguna de las preguntas durante la entrevista, o para continuar su participación, puede decirlo y pasaré a la siguiente pregunta o detendré la sesión.

\section{$\underline{\text { Entre la Semana } 1 \text { \& Semana 2-Para crear un poema }}$}

Se le pedirá que se comprometa a crear un poema que exprese sus experiencias únicas con el dolor migratorio y sus efectos en su identidad.

Durante la segunda semana:

1. En su tiempo libre, a su propio ritmo; se le pedirá que reflexione sobre sus experiencias con el dolor migratorio como inmigrante latina y que cree un poema que describa sus experiencias con la migración, el dolor, la pérdida y sus efectos sobre su bienestar como mujer latina.

2. Su expresión poética se puede escribir en español o inglés, según el idioma con el que se sienta más cómodo al expresar sus experiencias.

3. Se espera que complete su expresión poética a tiempo antes de la cita final y que me envíe el poema como un archivo adjunto por correo electrónico un día antes de nuestra entrevista final para su discusión y análisis.

\section{Semana 3- Entrevista final / Presentación del poema}

El propósito de la entrevista final es que usted presente su poema para discusión y análisis.

Durante la entrevista final:

1. Se espera que finalices el poema y me lo envíes como un archivo adjunto por correo electrónico un día antes de la entrevista final.

2. Se le pedirá que lea su poema y que hable más en detalle sobre él, para analizarlo (por ejemplo, ¿cómo se sintió al escribirlo?)

Una copia de su poema permanecerá con el investigador principal con el propósito de analizarlo y usarlo como parte de la investigación. Su poema se incluirá en los resultados de esta investigación como un requisito para completar los estudios de posgrado del investigador principal en Trabajo Social. Tiene usted, derecho a conservar la copia original de su poema para sus registros.

Si el poema se presenta en español, los investigadores principales lo traducirán al inglés para presentar los hallazgos. Se le entregará una copia de la traducción de su poema para sus archivos.

\section{¿Qué tipo de estudio es y dónde será?}


El estudio de investigación tendrá la forma de un estudio cualitativo. Este estudio se utiliza cuando el tema es casi desconocido, o cuando el investigador quiere tener una mejor perspectiva de la experiencia de una persona (Faulkner y Faulkner, 2016). El estudio se realizará a través del estilo de entrevista telefónica. La ubicación donde se realizará la investigación será en una habitación privada cerrada que permita la confidencialidad y que satisfaga sus necesidades. Serás entrevistado un total de dos veces, de lunes a sábado dependiendo de tu disponibilidad, las entrevistas serán de 1 hora. Se le harán preguntas relacionadas con sus experiencias.

Las preguntas de la entrevista se guiarán por sus respuestas, pero seguirán una guía de entrevista. Por ejemplo:

1. Se le harán preguntas sobre la aclaración de cualquier tema que hable en su expresión artística (por ejemplo, en su poema habla sobre ... [xxx]?.,

2. El entrevistador le hará preguntas para obtener más información sobre un tema específico del que habla en su poema (p. Ej., Duelo migratorio; ¿Cómo ha lidiado con su duelo? O ¿Qué valores y tradiciones culturales han influido en su experiencia con el duelo migratorio en Canadá? ¿inmigrante?)

\section{COLECCIÓN DEMOGRÁFICA}

Debido a la naturaleza del proyecto de investigación, los siguientes datos demográficos se recopilarán durante la primera entrevista con su consentimiento:

a) Nombre

b) Años

c) Género

d) Etnicidad

La información recopilada de usted será:

- ¿Cuál es tu nombre?

- ¿Tienes 18 años o más?

- ¿Cuál es su género y etnia?

- ¿Cuál es su dirección de correo electrónico y / o número de teléfono?

\section{RECOMENDACIONES}

\section{¿Donde estarán los resultados de la investigación disponibles?}

Los resultados de la investigación estarán disponibles a través de un enlace al Repositorio digital de Ryerson.El Repositorio digital ha sido creado por la Universidad de Ryerson como un espacio para recopilar, preservar y proporcionar acceso en línea a la investigación creada por la comunidad 
de Ryerson. Todos los MRP, incluido mi MRP, se cargarán al Repositorio digital después de la finalización para que pueda obtener los resultados en su propio tiempo.

Después de cargar el MRP, puede acceder al Repositorio digital de Ryerson a través de este enlace:

\section{https://digital.library.ryerson.ca/}

El investigador principal estará disponible para cualquier pregunta que usted tenga durante su participación y después de que se presentan los resultados. La expresión poética será traducida al inglés por el investigador principal para presentar los hallazgos si es necesario.

\section{BENEFICIOS POTENCIALES}

No puedo garantizar que usted recibirá ningún beneficio por participar en este estudio. Sin embargo, un beneficio potencial de este estudio es que creará conciencia en la sociedad canadiense de las pérdidas que enfrentan los inmigrantes y la influencia que tiene en su experiencia con el duelo en su proceso de aclimatarse a un nuevo país. Otro beneficio es que los hallazgos de este proyecto de investigación pueden guiar al Trabajo Social y a los académicos a comprender a la diáspora Latina en temas específicos de duelo migratorio y duelo cultural y los factores influyentes que contribuyen a su aculturación en Canadá.

Por último, los hallazgos presentarán una mejor comprensión de las experiencias de duelo, perdidas y desafíos únicos que enfrentan las mujeres Latinas cuando inmigran, esos hallazgos pueden ayudar a informar prácticas y servicios diseñados para mujeres latinas.

\section{¿CUÁLES SON LOS RIESGOS POTENCIALES PARA USTED COMO PARTICIPANTE?}

Debido a la naturaleza personal de compartir sus experiencias personales de pérdida y pena de abandonar su país de origen y emigrar a Canadá, existe el riesgo de que durante las entrevistas o durante el tiempo que lleva escribir el poema o el pensamiento poético, usted reflexione y recuerda algunos recuerdos desagradables.

En cualquier momento que se sienta incómodo o no desee responder ninguna de las preguntas durante las entrevistas, puede decirlo y el entrevistador pasará a la siguiente pregunta o punto del poema o análisis de pensamiento artístico. Este tema trata sobre su historia, por lo que, si en algún 
momento contarla le causa riesgos psicológicos como ansiedad o angustia emocional, usted o yo (el investigador) podemos decidir suspender temporalmente la entrevista, o finalizar el estudio de forma permanente.

El apoyo emocional y los servicios de referencia estarán disponibles durante la entrevista si las entrevistas crean un estrés indebido para usted. Se le proporcionará una lista de servicios sociales en su comunidad que ofrecen apoyo emocional y de inmigración en español e inglés en caso de que necesite apoyo adicional en su hogar o después del estudio. Antes y después del proceso de entrevista telefónica, enviaré por correo electrónico una lista de servicios de apoyo en inglés y español en su comunidad.

Se brindará apoyo emocional por teléfono. El investigador principal es un facilitador de apoyo de duelo que podrá ofrecerle apoyo individual durante la sesión si es necesario y solicitado. Por lo tanto, se realizará una técnica de relajación para el estado de ánimo como el paso final de su entrevista (por ejemplo, meditación de cierre de 5 minutos), esta terapia de atención plena se ha demostrado que es efectiva para reducir el estrés que es causado por el duelo a los participantes

Si usted durante las entrevistas, comparte conmigo información que pueda ser potencialmente una amenaza para usted o cualquier otra persona, como lastimarse a sí mismo o a otros, tengo el deber profesional de informar a las autoridades correspondientes. Me aseguraré de que usted tenga un nombre diferente en el estudio de investigación para proteger su identidad personal.

\section{CONFIDENCIALIDAD}

Todos los datos se almacenarán en Ryerson Google Share Drive. La poesía (poemas o expresiones poéticas) estará segura en el Ryerson Google share drive para que puedan incluirse en el MRP. Los poemas no tendrán información de identificación, se darán seudónimos y se asignarán a cada participante.

Todas las entrevistas serán grabadas en audio. Las grabaciones de audio se eliminarán después de la transcripción y verificación. Después de finalizar las entrevistas telefónicas, los poemas y las grabaciones de audio irán a la computadora y se guardarán y almacenarán en Ryerson Google Shared Drive, la unidad de almacenamiento Google de Ryerson minimiza el riesgo de que personas no autorizadas accedan a los datos porque es seguro y toda la información está encriptada. Todos los datos recopilados antes y durante el proceso de la entrevista se mantendrán confidenciales.

Los datos se almacenarán durante un período de un año y estarán disponibles para los participantes antes de la etapa de análisis de datos. Los datos de las transcripciones estarán disponibles para su revisión / edición hasta el 30 de Mayo de 2020, antes de la etapa de análisis de datos. Si después 
de esa fecha usted como participante no aporta ningún cambio o información, se supondrá que usted está satisfecha con las transcripciones tal y como están y se procederá a la siguiente etapa Las transcripciones se almacenarán por un período de 1 año. Las transcripciones se enviarán a los participantes por correo electrónico con archivo adjunto en la unidad de almacenamiento Google de Ryerson (Ryerson Google Share Drive) que está protegido con contraseña.

Tiene derecho antes de Mayo 30,2020 a revisar / editar las transcripciones. Sin embargo, si alguna de la información proporcionada puede ser percibida como una amenaza para usted, los participantes o cualquier persona. Yo, como investigador principal, tengo el deber profesional de informar la información a las autoridades legales si es necesario.

Todos los datos recopilados antes y durante el proceso de la entrevista se mantendrán confidenciales. Tiene usted derecho a revisar / editar las grabaciones, usted puede solicitar en cualquier momento durante la duración de este estudio para revisar las cintas de audio y / o transcripciones. Sin embargo, si alguna de la información proporcionada por usted durante las entrevistas puede ser potencialmente una amenaza para usted, los demás participantes o cualquier persona. Yo, como investigador principal, tengo el deber profesional de informar a las autoridades correspondientes.

\section{INCENTIVOS PARA LA PARTICIPACIÓN:}

No se ofrecerán incentivos por su participación.

\section{COSTOS A LA PARTICIPACIÓN:}

No hay costos asociados con su participación.

\section{PARTICIPACIÓN VOLUNTARIA Y RETIRAR PARTICIPACIÓN}

La participación en este estudio es completamente voluntaria. Puede usted elegir si participa en este estudio o no. Si alguna pregunta le hace sentir incómoda, puede saltarte esa pregunta. Si decide dejar de participar, también puede optar por no incluir sus datos en el estudio.

Su elección de participar o no, esta decisión no influirá en sus futuras relaciones con la Universidad de Ryerson o los investigadores Covadonga Blanco (investigador principal) y Ken Moffatt (supervisor) involucrados en la investigación.

En caso de que decida no hacer el poema, su participación puede finalizar sin su consentimiento. Debido a la naturaleza de este proyecto, es necesaria una expresión poética para informar esta 
investigación, su expresión poética contribuirá a asesorar este proyecto, sin una expresión poética este proyecto podría no ser posible.

\section{PREGUNTAS SOBRE EL ESTUDIO}

Si tiene alguna pregunta sobre la investigación ahora, por favor pregunte. Si tiene preguntas más adelante sobre la investigación, puede comunicarse con:

\begin{tabular}{|l|c|c|}
\hline \multicolumn{1}{|c|}{ Nombre } & Correo Electronico & Posición \\
\hline 1. Covadonga Blanco BSW,SSW & cblancom @ryerson.ca & Investigador Principal \\
\hline 2. Ken Moffatt PhD & kmoffatt@ryerson.ca & Supervisor \\
\hline
\end{tabular}

Este estudio ha sido revisado por la Junta de Ética de Investigación de la Universidad de Ryerson. Si tiene preguntas sobre sus derechos como participante en este estudio, comuníquese con:

Research Ethics Board/ Junta de Ética de Investigación / c/o Office of the Vice President, Research and Innovation / c / o Oficina del Vicepresidente de Investigación e Innovación Ryerson University 350 Victoria Street Toronto, ON M5B 2K3 Telefono :416-979-5042

Correo electronico: rebchair@ryerson.ca 


\section{De su propia voz, el impacto del duelo cultual y luto migratorio en Latinas viviendo en Canadá. \\ (In their own voices, the impact of cultural bereavement and grief migration on Latinas in Canada)}

\section{ACUERDO DE CONFIRMACION:}

En la parte de abajo,al seleccionar la casilla de "SI" y escribir su nombre completo, usted indica que usted ha leído la información en este acuerdo y ha tenido la oportunidad de hacer cualquier pregunta que tenga sobre el estudio.

En la parte de abajo, al seleccionar la casilla de "SI" y escribir su nombre completo, , indica que acepta participar en el estudio y que le han informado que puede cambiar de opinión y retirar su consentimiento para participar en cualquier momento.

Al seleccionar en la parte de abajo la casilla de "SI" y escribir su nombre completo, usted indica que le han dado una copia de este acuerdo. Le han informado también que al firmar este acuerdo de consentimiento no renuncia a ninguno de sus derechos legales.

\section{Al seleccionar en la parte de abajo la casilla de verificación "SÍ" está usted firmando este} Acuerdo de Conformación electrónicamente.

Acepta participar en este estudio?

$\bigcirc \mathrm{Si}$, estoy de acuerdo

No, no estoy de acuerdo

*Al seleccionar la casilla de verificación "SÍ" usted está firmando este Acuerdo de Conformación electrónicamente

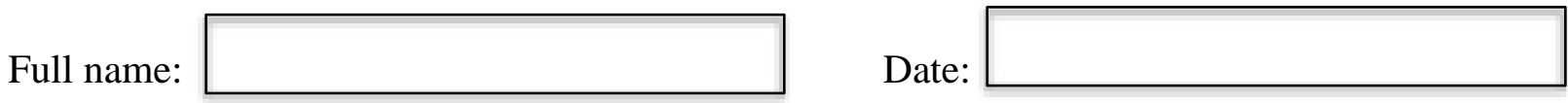

*Al escribir su nombre y seleccionar la casilla de verificación "SÍ" usted está firmando este Acuerdo de Conformación electrónicamente

\section{Declaracion}

Confirmo que no he sido forzada de ninguna manera a dar mi consentimiento, y que mi consentimiento lo estoy dado de forma libre y voluntaria.

$\mathrm{Si}$, estoy de acuerdo

No, no estoy de acuerdo

Confirmo que se me dio la oportunidad de hacer preguntas sobre el estudio, y que todas mis preguntas han sido respondidas correctamente y con la mejor intención y capacidad del investigador principal.

$\mathrm{Si}$, estoy de acuerdo 
No, no estoy de acuerdo

\section{Autorización para ser grabado en audio}

Acepto ser grabado en audio para los propósitos de este estudio. Entiendo cómo se almacenarán y destruirán estas grabaciones.

$\mathrm{Si}$, estoy de acuerdo

No, no estoy de acuerdo

*Al seleccionar la casilla de verificación "SÍ" usted está aceptando ser grabado en audio.

Confirmo que se me dio la oportunidad de hacer preguntas sobre el estudio, y que todas las preguntas han sido respondidas correctamente y de la mejor manera posible del Investigador Principal.

$\mathrm{Si}$, estoy de acuerdo

No, no estoy de acuerdo

\section{Forma de Consentimiento}

Gracias por aceptar participar en este estudio. Usted recibirá por correo electrónico una copia de la forma que usted acaba de llenar.

Si desea una extra copia en Inglés o en Español, el acuerdo de consentimiento está disponible en español e inglés para que lo baje y lo guarde en sus archivos.

Para obtener una copia del acuerdo, haga click en el link de abajo en el idioma correspondiente para acceder a la forma y poderla bajar a su computadora.

Bajar Forma de Consentimiento

English:

Spanish: https://drive.google.com/file/english

https://drive.google.com/file/spanish

\section{Declina Participación}

Usted ha decidido no participar en este estudio, de le click al botón de submit o simplemente cierre su ventana para salir del programa. 


\section{APPENDIX D - INTERVIEW GUIDE IN ENGLISH}

\section{Semi-Structured Interview Guide}

A semi-structured interview format has been chosen for the project with the purpose of exploring more possible topics that can arise from the poetry that participants will do as a method of data collection.

The interviewer will have more freedom to word questions spontaneously, and the participants will have the opportunity to answer more broadly and to describe their experiences deeply with grief, migration and loss written in their poems.

The question will be asked in Spanish or English. It will be up to the participants to decide in what language they feel more comfortable responding and sharing their experiences.

Semi-Structured Interview Questions:

\section{Initial Interview}

To begin this interview, I'd like to ask you some questions about the country where you grew up.

I. Let's begin by discussing the country that you grew up in.

1. Tell me about your home country?

2. What are the reasons that cause you to immigrate to Canada?

II. Instruction to create a Poem.

1. During week two in your free time, at your own leisure; you will be asked to create a or poem describing your experiences with migration, grief, loss and their effects on your wellbeing during your free time

In your poetry, you are required to talk about:

- Your experiences with grief and loss leaving your country

- How those experiences have influenced your life in Canada.

- As a woman

- Latina

- Immigrant

- How your cultural values and traditions have influenced those experiences. 
Your poetry can be written in Spanish or English, depending on what language you feel more comfortable expressing your experiences.

3. At your leisure and at your own time, you will have the freedom to create your poetic expression and to reflect on your experiences with migratory grief as a Latina immigrant.

\section{Final Interview}

1. Share your poem; please read it

2. Tell me about your poem...

3. In your poem, you said that......[xxx]?

- Is that correct?

- If says yes: Does that mean that?

- If says no: Then what it means?

1. In the poem, you tall about what did you leave behind to tell me...

a) How that has affected your life in Canada

- As a Latina

- As a woman

- Immigrant

1. How did you cope with those losses?

2. How have you dealt with your grief?

3. What cultural values and traditions have influenced your experience with migratory grief in Canada as an immigrant?

4. Tell more about your migratory grief and losses...

5. As a Latina have your encounter challenges in

- Immigration process

- Acculturation to Canada

- In your home country

- If yes, how have they affected your identity?

The following unstructured questions will be asked to allow the interviewee to guide the conversation; those questions will be reworded spontaneously according to participants' poetry. 
1. Tell me more about that.

2. How did you feel about that?

3. What do you mean when you say $[\mathrm{xxx}]$ ?

\section{$\underline{\text { Closing }}$}

1. Before we conclude this interview, is there something about your experience with migratory grief and loss that we have not discuss?

2. Is there something else that you want to share or add? 


\section{APPENDIX E - INTERVIEW GUIDE IN SPANISH}

\section{Guia para Entrevista Semi-structurada}

Se eligió un formato de entrevista semiestructurada para el proyecto con el propósito de explorar los más temas posibles que puedan surgir del poema que la participante hará como método de recolección de datos.

El entrevistador tendrá más libertad para formular preguntas espontáneamente y los participantes tendrán la oportunidad de responder de manera más amplia y describir profundamente sus experiencias con el dolor, la migración y la pérdida escritas en sus poemas.

La pregunta se hará en español o inglés. Depende de los participantes decidir en qué idioma se sienten más cómodos respondiendo y compartiendo sus experiencias.

\section{Preguntas de la entrevista semiestructurada}

\section{Entrevista inicial}

I. Para comenzar esta entrevista, me gustaría hacerle algunas preguntas sobre el país donde creció.

Comencemos por hablar sobre el país en el que creciste.

1. ¿Cuéntame sobre tu país de origen?

2. ¿Cuál es la razón que te hace emigrar a Canadá?

II. Instrucción para crear poema.

Durante la segunda semana se le pedirá que: 
- En su tiempo libre, a su propio ritmo usted cree un poema que describa sus experiencias con la migración, el dolor, la pérdida y sus efectos en su bienestar durante su vida en Canadá.

En su poema se espera que usted escriba acerca de lo siguiente:

1. Sus experiencias con el dolor y la pérdida al salir de su país.

2. Cómo esas experiencias han influido en tu vida en Canadá.

- como mujer

- latina

- emígrate

3. Cómo sus valores culturales y tradiciones tienen influencia en esas experiencias

- Su expresión poética se puede escribir en español o inglés dependiendo del idioma en que se sienta usted más cómoda al expresar sus experiencias.

- En su tiempo libre tendrá la libertad de crear su expresión poética y reflexionar sobre sus experiencias con el dolor migratorio como inmigrante Latina.

\section{Entrevista final}

1. Comparte tu poema, por favor léelo...

2. Cuéntame sobre tu poema ...

3. ¿En tu poema hablas acerca de... [xxx]? ¿Es correcto?

- Si dice sí: ¿Eso significa ...?

- Si dice no: ¿entonces qué significa?

4. En tu poema escribes de tus perdidas, acera de lo que dejaste dime...

a. Como han afectado tu vida en Canadá 


$$
\begin{aligned}
& \text { - Como Latina } \\
& \text { - Como mujer } \\
& \circ \text { Como inmigrante }
\end{aligned}
$$

5. ¿Cómo hizo frente a esas pérdidas?

6. ¿Como has lidiado con tu duelo migratorio?

7. ¿Qué valores culturales y tradiciones influyen en su experiencia con el dolor migratorio en Canadá como inmigrante?

8. Cuenta me más sobre tu duelo migratorio y tus pérdidas...

9. Como Latina ha tenido desafíos

- Proceso de emigración

- Aculturación a Canadá

- En su país de origen

10. En caso afirmativo, ¿cómo han afectado su identidad?

Se usarán las siguientes preguntas no estructuradas con el objetivo que permitan al entrevistado guiar la conversación, esas preguntas se redactarán o redactarán espontáneamente de acuerdo con las expresiones poéticas de los participantes.

1. Cuéntame más sobre eso.

2. ¿Y cómo te sentiste al respecto?

3. ¿Qué quieres decir cuando dices $[\mathrm{xxx}]$ ?

\section{Conclusión}

Antes de concluir esta entrevista,

1. ¿hay algo acerca de su experiencia con el dolor y la pérdida migratoria que no hayamos discutido?

2. ¿Hay algo más que quiera compartir o agregar? 


\title{
APPENDIX F- LIST OF RESOURCES IN ENGLISH AND SPANISH
}

\author{
Support Resources for the Latin America community in Toronto \\ Servicios de Apoyo para la comunidad Latina en Toronto \\ Community \& Settlement counselling and support services \\ Servicios comunitarios, de inmigración y de apoyo a la comunidad Latina
}

\section{Phone Support/Apoyo telefonico \\ Distress Centres of Greater Toronto \\ - Lineas telefonicas de ayuda /Helpline Numbers: \\ ○ https://www.torontodistresscentre.com/ \\ - 905-459-7777 (Brampton \& Mississauga) spanish line/linea en espanol \\ ○ Text to 45645 /Puede textear por apoyo al 45645}

- English Helplines are open 24 hours a day, 7 days a week, 365 days a year/Líneas telefónica de ayuda en Ingles los 365 días del ano, los 7 días de la semana, las 24 horas al día

- Multilingual Phone Helplines. Monday to Friday, 10am - 10pm/Lineas Telefonica en different lenguas, disponibles de Lunes a Viernes de 10am-10pm

- Crisis and Distress lines in Spanish / Lineas de crisis y angustia en Spanish

- Services are confidential, easy to access, non-judgmental and totally free/ Servicios son confidenciales, facil de accesar, y sin costo alguno

- In case of emergency dial 911/EN caso de emergencia marque al 911

\section{Individual Counselling /Terapia Individual}

\section{Encuentro Latino}

1700 Wilson Ave, Suite 114, Toronto, M3L 1B2

Phone: (416) 244-0480 | Fax: (416) 244-0379

Email: nyork@costi.org | www.costi.org

- Spanish Services/Servicios en español

- Terapias individuales sin costo

Family Service Toronto

355 Church Street, Toronto, M5B $1 Z 8$

Phone: 416-595-9230 | Fax: 416-595-0242 |

http://www.familyservicetoronto.org/programs/seniors.html

- Spanish Services/Servicios en español 
- Counselling services ( family, domestic violence, individual and crisis )/ Terapias sin costo (familiares, violencia doméstica, individuales, y crisis)

\section{Centre for Information and Community Services of Ontario}

2330 Midland Ave, Toronto, M1S 5G1

Phone: (416) 292-7510 | Fax: (416) 292-9120

Email: info@cicscanada.com | www.cicscanada.com

- Spanish Services/Servicios en español

- Information, referrals, immigration and commutiy services / Servicios de Información, referencia, inmigración, Apoyo comunitario

\section{Social Work /Servicio Social}

\section{AYCREST}

3560 Bathurst St.

Toronto, ON M6A 2 E1

t. 416-785-2500

www.baycrest.org

Social Services/Servicios Sociales:

- Offers weekly friendly telephone calls and email messages /Ofrece llamadas semanales y mensajes de correo electrónico para apoyo emocional.

- Access to a social worker for information, referral or brief counselling upon request /Acceso a trabajadora social para información, referencias de servicios y breve terapia individual

\section{CENTRE FOR SPANISH SPEAKING PEOPLES}

2141 Jane St., 2nd Floor

Toronto, ON M3M 1 A2

t. 416-533-8545

www.spanishservices.org

- Social Services/Servicios Sociales

- Offers support in filling out official documents and applications /Apoyo con llenando y completar documentación oficial y aplicaciones.

\section{WEST NEIGHBOURHOOD HOUSE}

248 Ossington Ave.

Toronto, ON M6J 3A2

t. $416-532-4828$

www.westnh.org

- Social Services/Servicios Sociales 
- Offers a program that provides lunch while updating attendees on services and educating them on what is available in the community /Ofrece programa que provén almuerzo mientras que presentan conferencias con información y servicios disponible sen la comunidad.

\section{Emergency services and non-emergency services}

Emergency Multi-lingual 9-1-1 Service

- If you do not speak English, translation services for over 140 languages are available through

- 9-1-1 / Servicios de traducción en más de diferentes lenguajes están disponibles al marcar

9-1-1.

Ask for service in your language if you cannot explain the situation in English, or if you cannot understand the call-taker/ Al marcar pida servicios en español.

Non-Emergency Services/Servicios de no Emergencias

$\underline{211}$

- Call 2-1-1 for information and referral to community and social services. 211 is free, confidential, multilingual and available 24-hours a day /Llama para referencias a servicios sociales dentro de la comunidad, Servicio gratuito, en español y disponible las 24 horas del día. 


\section{Support Resources for the Latin America community in Peel Region Servicios de Apoyo para la comunidad Latina en la Región de Peel}

Community \& Settlement counselling and support services

Servicios comunitarios, de inmigración y de apoyo a la comunidad Latina

\section{$\underline{\text { Mississauga }}$}

\section{Distress Centres of Greater Toronto (Spectra Helpine)}

- Lineas telefonicas de ayuda /Helpline Numbers:

○ 905-459-7777 (Brampton \& Mississauga)

○ 1-877-298-5444 (Caledon)

○ 905-278-4890 (TTY)

- English Helplines are open 24 hours a day, 7 days a week, 365 days a year/Lineas telefónica de ayuda en Ingles los 365 dias del ano, los 7 días de la semana, las 24 horas al día

- Multilingual Phone Helplines. Monday to Friday, 10am - 10pm/Lineas Telefonica en different lenguas, disponibles de Lunes a Viernes de 10am-10pm

- Crisis and Distress lines in Spanish /Lineas de crisis y angustia en Spanish

- Services are confidential, easy to access, non-judgmental and totally free./ Servicios son confidenciales, facil de accesar, y sin costo alguno

\section{Catholic Cross-cultural Services}

3660 Hurontario St., 7th floor

Mississauga, ON L5B 3C4

Tel: 905-273-4140

Spanish Services/Servicios en español

\section{Catholic Family Services}

10 Kingsbridge Garden Circle Unit 400

Mississauga, ON L5R 3K6

Tel: 905-897-1644

Spanish Services/Servicios en español

\section{Dixie Bloor Neighbourhood Services Centre}

3650 Dixie Rd, Unit 103

Mississauga, ON L4Y 3V9

Tel: 905-629-1873

Spanish Services/Servicios en español

Family Services of Peel - Mississauga

151 City Centre Dr., Suite 501

Mississauga, ON L5B 1M7 
Tel: 905-270-2250

Spanish Services/Servicios en español

- Must call the intake office to schedule an appointment beforehand 905-4535775 / Llama con anterioridad para sacar cita al telefono:905-453-5775

Newcomer Centre of Peel

165 Dundas St W, Suite 116

Mississauga, ON L5B 2N6

Tel: 905-306 0577, 905-306-1275

Spanish Services/Servicios en español

\section{$\underline{\text { Malton }}$}

Family Services of Peel - Malton

6870 Goreway Dr., Unit 201

Mississauga, ON L4V 1P1

Tel: 905-453-5775

Services in Spanish/Servicios en español

- You must call the intake office to schedule an appointment beforehand/ Llama con anterioridad para sacar cita.

Malton Neighbourhood Services

3540 Morning Star Dr,

Mississauga, ON L4T 1Y2

Tel: 905-677-6270

- Translation services can be arranged/ Call beforehand to make appointment

\section{Brampton}

\section{Catholic Crosscultural Services}

8 Nelson St. W, Suite 302

Brampton, ON L6X 4J2

Tel: 905-457-7740

Spanish Services/Servicios en español

\section{Catholic Family Services}

60 West Drive, Suite 201

Brampton, ON L6T 3T6

Tel: 905-450-1608

Spanish Services/Servicios en español

\section{Family Services of Peel}


60 West Drive, Suite 209

Brampton, ON L6T 3T6

Tel: 905-453-5775

Spanish Services/Servicios en español

- Must call the intake office to schedule an appointment beforehand 905-453-5775 /Llamar con anterioridad al telefono 905-453-5775 para sacar cita.

\section{COSTI Immigrant Services}

Centennial Mall

227 Vodden St E, Unit 3

Brampton, ON L6V $3 E 7$

Tel: 905-459-6700

Spanish Services/Servicios en español

\section{YMCA of Greater Toronto}

20 Union Street

Brampton, ON, L6V $1 R 2$

Tel: 905-451-9622

Translation services can be arranged/ Call beforehand to make appointment

\section{Caledon}

\section{Caledon Community Services}

18 King St. E, Upper Level

Caledon, ON L7E 1E8

Tel: 905-584-9460

Translation services can be arranged/ Call beforehand to make appointment

\section{Emergency services and non-emergency services}

Emergency Multi-lingual 9-1-1 Service

- If you do not speak English, translation services are available through 9-1-1 /Servicios de traducción en más de diferentes lenguajes están disponibles al marcar 9-1-1.

- Ask for service in your language if you cannot explain the situation in English, or if you cannot understand the call-taker/ Al marcar pida servicios en español.

Non-Emergency Services

$\underline{211}$

- Call 2-1-1 for information and referral to community and social services. 211 is free, confidential, multilingual and available 24-hours a day / Llama para referencias a servicios sociales dentro de la comunidad, Servicio gratuito, en español y disponible las 24 horas del día. 


\section{REFERENCES}

Achotegui, J. (2019). Migrants living in very hard situations: Extreme migratory mourning (the Ulysses syndrome). Psychoanalytic Dialogues, 29(3), 252-268.

doi:10.1080/10481885.2019.1614826

Anzalda, G. (1990). Haciendo caras, una entrada. In G.Anzalda (Ed.), Making face,making soul: Creative and critical perspectives by feminists of color (p. 371-377).San Francisco, CA: Aunt Lute Books.

Ayala, E. S., \& Dalouh, R. (2014). Moroccan immigrant women in Spain: Problems of identity and emotional well-being. Procedia - Social and Behavioral Sciences, 132, 222-228. doi: 10.1016/j.sbspro.2014.04.302

Ayón, C., Valencia-Garcia, D., \& Kim, S. H. (2017). Latino immigrant families and restrictive immigration climate: Perceived experiences with discrimination, threat to family, social exclusion, Children's vulnerability, and related factors. Race and Social Problems, 9(4), 300-312. doi:10.1007/s12552-017-9215-Z

Ayón, C., Wagaman, M. A., \& Philbin, S. P. (2018). No te dejes pisotear por nadien: Examining Latino immigrants' efforts to resist discrimination. Journal of Social Service Research, 44(1), 78-95. doi:10.1080/01488376.2017.1395381

Aylward, C. A. (1999). Canadian critical race theory: Racism and the law Fernwood.

Becvar, D. S. (2013). Familias Fuertes: Family resilience along Latinos. In D. S. Becvar (Ed.), Handbook of family resilience (p. 205-227). Springer Science. Business Media. https://doi.org/10.1007/978-1-4614-3917-2_24

Bishop, E., \& Willis, K. (2014). "hope is that fiery feeling": Using poetry as data to explore the meanings of hope for young people. Forum: Qualitative Social Research, 15(1) 
Bhugra, D. (2004). Migration and mental health. Acta Psychiatrica Scandinavica, 109(4), 243258. doi:10.1046/j.0001-690X.2003.00246.x

Bhugra, D., \& Ayonrinde, O. (2004). Depression in migrants and ethnic minorities. Advances in Psychiatric Treatment, 10(1), 13-17. doi:10.1192/apt.10.1.13

Bhugra, D., \& Becker, M. A. (2005). Migration, cultural bereavement and cultural identity. World Psychiatry: Official Journal of the World Psychiatric Association (WPA), 4(1), 1824.

Bhuyan, R., Osborne, B. J., \& Cruz, J. F. J. (2016). “Once you arrive, se te sala todo" (everything is salted): Latina migrants' search for "Dignity and a right to life" in Canada. Journal of Immigrant \& Refugee Studies, 14(4), 411-431. doi:10.1080/15562948.2016.1147630

Bold, C. (2012). Using Narrative in Research. Lodon: Sage.

Bonanno, G. A. (2004). Loss, trauma, and human resilience: Have we underestimated the human capacity to thrive after extremely aversive events? American Psychologist, 59(1), 20-28. doi:10.1037/0003-066X.59.1.20

Bonanno, G. A., \& Kaltman, S. (2001). The varieties of grief experience. Clinical Psychology Review, 21(5), 705-734. doi:10.1016/S0272-7358(00)00062-3

Bucher-Maluschke, J., Gondim, M., \& Pedroso, J. d. S. (2017). The effects of migration on family relationships: Case studies. International Journal of Migration, Health and Social Care, 13(2), 198-206. doi:10.1108/IJMHSC-05-2015-0016

Buskirk, M. (2003). The contingent object of contemporary art. Cambridge, MA: MIT Press.

Cahnmann, M. (2003). The craft, practice, and possibility of poetry in educational research. Educational Researcher, 32, 29-36. DOI: 10.3102/0013189X032003029 
Calero, C. (2017). Latinx students in the GTA and surroundings and high school disengagement. Ryerson University.

Carr, J. M., (2003). Poetic expressions of vigilance. Qualitative Health Research, 13, 1324-1331. Carr-Ruffino. N., (1999). Diversity success strategies. Butterworth-Heinemann, 322 pages. New York: Wiley Subscription Services, Inc., A Wiley Company. doi:10.1002/hrm.10037

Casado, B. L., Hong, M., \& Harrington, D. (2010). Measuring Migratory Grief and Loss Associated with the Experience of Immigration. Research on Social Work Practice, 20(6), 611-620. doi.org/10.1177/1049731509360840

Casado, B.L. \& Leung, P. (2001). Migratory grief and depression among elderly Chinese American immigrants. Journal of gerontological social work, 36(1-2), 5-26.

Castillo, L. G., Perez, F. V., Castillo, R., \& Ghosheh, M. R. (2010). Construction and initial validation of the marianismo beliefs scale. Counselling Psychology Quarterly, 23(2), 163175. doi:10.1080/09515071003776036

Chatterjee, S. (2019). Immigration, anti-racism, and indigenous self-determination: Towards a comprehensive analysis of the contemporary settler colonial. Social Identities, 25(5), 644661.

Christoph, N. (2014). Mexican immigrant women's poetry: Voices from a community poetry class. Carmen. Personal interview. Pacific Coast Philology, 49(2), 221-244. doi:10.5325/pacicoasphil.49.2.0221

Clandinin, D.J., (2007). Handbook of Narrative Inquiry: Mapping a Methodology. SAGE.

Cleary, S. D., Snead, R., Dietz-Chavez, D., Rivera, I., \& Edberg, M. C. (2017;2018;). Immigrant trauma and mental health outcomes among Latino youth. Journal of Immigrant and Minority Health, 20(5), 1053-1059. doi:10.1007/s10903-017-0673-6 
Crenshaw, K. (1995). Critical race theory: The key writings that formed the movement $\mathrm{New}$ Press.

Creswell, J. W. (2013). Qualitative inquiry and research design: Choosing among five approaches (3rd ed.). Los Angeles, CA: SAGE Publications.

Dalla, R., Amarapurkar, S., Bates L., Balter B.L., (2009) Strengths and Challenges of New Immigrant Families: Implications for Research, Education, Policy, and Service. Lexington Books.ISBN-10: 0739114565. ISBN-13: 978-0739114568

Dei, G. J. S. (2000). Toward an anti-racism discursive framework. In G. J. S Dei \& A. Calliste (Eds.), power, knowledge and anti-racism education: A critical reader (pp. 23-40). Halifax, NS: Fernwood Publishing

De la Revilla, L., de los Ríos Álvarez, A. M, de Dios Luna del Castillo, J., Gómez García, M., Valverde Morillas, C., \& López Torres, G. (2010). Estudio del duelo migratorio en pacientes inmigrantes que acuden a las consultas de atención primaria. presentación de un cuestionario de valoración del duelo migratorio. Atención Primaria, 43(9), 467-473. doi: 10.1016/j.aprim.2010.09.013

Delgado, R., \& Stefancic, J. (1994). Hateful speech, loving communities: Why our notion of "a just balance" changes so slowly. California Law Review, 82(4), 851.

Delgado, R., \& Stefancic, J. (1998). Critical race theory: Past, present, and future. Current Legal Problems, 51(1), 467-491. doi:10.1093/clp/51.1.467

Delgado, R.\& Stefancic, J., (2013). Critical Race Theory: The Cutting-Edge 3rd ed. Philadelphia: Temple University Press,

Delgado, R., Stefancic, J., \& Harris, A. P. (2017). Critical race theory: An introduction (Third ed.). New York: New York University Press. 
De Snyder, V.N., (1987). The role of ethnic loyalty among Mexican immigrant women. Hispanic Journal of Behavioral Sciences, 9(3), 287-298. doi:10.1177/07399863870093005

Deaux, K., Foner, N., \& Donato, K. M. (2018). Introduction: Immigration and changing identities. RSF: The Russell Sage Foundation. Journal of the Social Sciences, 4(5), 1-25. doi:10.7758/rsf.2018.4.5.01

Diaz, V. E., Molina, A. N., \& Marín, M. A. (2015). Las pérdidas y los duelos en personas afectadas por el desplazamiento forzado /Loss and grief in persons affected by forced displacement. Pensamiento Psicologico, 13(1), 65

Doka, K. (2002). Introduction. In K. Doka (Ed.), Disenfranchised grief: New directions, challenges, and strategies for practice (pp. 5-22). Champaign, IL: Research Press.

Eisenbruch M. (1984); Cross-cultural aspects of bereavement. II. Ethnic and cultural variations in the development of bereavement practices. Culture, Med. Psychiatry. Vol. 8,315-347.

Eisenbruch, M. (1990). The cultural bereavement interview: A new clinical research approach for refugees. Psychiatric Clinics of North America, 13(4), 715-735.

Eisenbruch, M. (1991). From post-traumatic stress disorder to cultural bereavement: Diagnosis of southeast Asian refugees. Social Science \& Medicine, 33(6), 673-680. doi:10.1016/0277-9536(91)90021-4

Erlingsson, C., \& Brysiewicz, P. (2013). Orientation among multiple truths: An introduction to qualitative research. African Journal of Emergency Medicine, 3(2), 92-99. doi: 10.1016/j.afjem.2012.04.005

Fernando, S., \& Rinaldi, J. (2017). Seeking Equity: Disrupting a History of Exclusionary Immigration Frameworks. Canadian Ethnic Studies 49(3), 7-26. doi:10.1353/ces.2017.0019. 
Ferreira, A. M., (2014). A Look into the Latino Experience: The Process of Identity Formation for Latinos in the United States. Claremont College. Senior Theses. 886. Retrieved from: http://scholarship.claremont.edu/cmc_theses/886

Flake, D. F., \& Forste, R. (2006). Fighting families: Family characteristics associated with domestic violence in five Latin American countries. Journal of Family Violence, 21(1), 19-29. doi:10.1007/s10896-005-9002-2

Flippen, C. A., \& Parrado, E. A. (2015). Perceived discrimination among Latino immigrants in new destinations: The case of Durham, NC1. Sociological Perspectives. Pacific Sociological Association, 58(4), 666-685. doi:10.1177/0731121415574397

Fraser, H. (2004). Doing narrative research: Analysing personal stories line by line. Qualitative Social Work, 3(2), 179-201. doi:10.1177/1473325004043383

Fraser, N., \& Nicholson, L. (1990). Social criticism without philosophy: An encounter between feminism and postmodernism. Theory, Culture \& Society, 5(2-3), 373-394. doi:10.1177/0263276488005002009

Furman, R., Negi, N. J., Iwamoto, D. K., Rowan, D., Shukraft, A., \& Gragg, J. (2009). Social work practice with Latinos: Key issues for social workers. Social Work, 54(2), 167-174. doi:10.1093/sw/54.2.167

Galvin, K. T., \& Prendergast, M. (2016). Poetic inquiry II: Seeing, caring, understanding: Using poetry as and for inquiry. Rotterdam: Sense Publishers. doi:10.1007/978-94-6300-316-2

Gastaldo, D. (2014). Biographical Erasure as Oppression. Journal of Critical Anti-Oppressive Social Inquiry, 1(1).62-66 
Gil, A. G., \& Vega, W. A. (1996). Two different worlds: Acculturation stress and adaptation among Cuban and Nicaraguan families. Journal of Social and Personal Relationships. 13(3), 435-456. doi:10.1177/0265407596133008

Gilligan, C. (1982). In a different voice: Psychological theory and women's development. Cambridge, MA: Harvard University Press.

Gilligan, C., Spencer, R., Weinberg, K., \& Bertsch, T. (2003). On the listening guide: A voicecentered relational method. In P. M. Camic, J. E. Rhodes, \& L. Yardley (Eds.), Qualitative research in psychology: Expanding perspectives in methodology and design, (pp. 157-172).

Washington, DC: American Psychological Association. doi:10.1037/10595-009

Gil, R. M., \& Vazquez, C. I. (1997). The Maria paradox: how Latinas can merge Old World traditions with New World self-esteem. Bloomington, IN: Scenery Press.

Gonzalez, D.A., (2005). "Migrating Latinas and the Grief Process.” Brigham Young University. All Theses and Dissertations. Retrieved from: https://scholarsarchive.byu.edu/etd/760

Gonzalez, N., \& Méndez-Pounds, J. (2018). The impact of acculturation and cultural values on Hispanic immigrants' parenting. Contemporary Family Therapy, 40(1), 56-67. doi:10.1007/s10591-017-9428-8

Glaser, D. (2017). Working with sexual violence in the Latinx community: Testimonios and stories of racialized women workers. Digital Repository. Ryerson University

Grillo, T. (1995). Anti-essentialism and intersectionality: Tools to dismantle the master's house. Berkeley Women's Law Journal, 10, 16.

Grinberg, L., \& Grinberg, R. (1989). Psychoanalytic perspectives on migration and exile. New Haven \& London: Yale University Press 
Guerra, G., \& Orbea, G. (2015, Nov 19). The argument against the use of the term "latinx". University Wire. Latin American Studies, Latinx, linguistics.

Harper, S. B. (2017). No way out: Severely abused Latina women, patriarchal terrorism, and self-help homicide. Feminist Criminology, 12(3), 224-247. doi:10.1177/1557085116680743

Healy, K. (2005). Social work theories in context: Creating frameworks for practice. Houndmills, UK: Palgrave Macmillan.

Held, V. (2006 ). The Ethics of Care as a Moral Theory. The ethics of care: Personal, political, and global. (pp.1-34) Oxford University Press.

Hernandez, J., \& Torres, B. (2015, Dec 03). A response to "the argument against the use of the term 'Latinx'". University Wire. http://libproxy.ung.edu/login?url=http://search.proquest.com/docview/1746662029?acco untid=159965

Hernandez-Truyol, B. (1997). Borders (en)gendered: Normativities, Latinas and a LatCrit paradigm. New York University. Law Review, 72, 882-927.

Holman Jones, S. L., Adams, T. E., \& Ellis, C. (2015). Handbook of autoethnography. Individual and Collaborative Autoethnography as Method. Chapter 3. Left Coast Press, Inc.

Hondagneu-Sotelo, P. (1992). Overcoming patriarchal constraints: The reconstruction of gender relations among Mexican immigrant women and men. Gender \& Society, 6(3), 393-415. doi:10.1177/089124392006003004

Houben, L. (2012). Counselling Hispanics through loss, grief and bereavement: A guide for mental health professionals Springer publishing company. Journal of Social Work in End-of-Life \& Palliative Care, 9(4), 369-372. doi:10.1080/15524256.2013.847150 
Horton, S. (2009). A mother's heart is weighed down with stones: A phenomenological approach to the experience of transnational motherhood. Culture, Medicine and Psychiatry, 33(1), 21. doi:10.1007/s11013-008-9117-

Hunnicutt, G. (2009). Varieties of patriarchy and violence against women: Resurrecting "patriarchy" as a theoretical tool. Violence Against Women, 15(5), 553-573. doi:10.1177/1077801208331246

Johnson, K. R. (1998). Immigration and Latino Identity. Chicana/o Latina/o Law Review, 19(1). Retrieved from https://escholarship.org/uc/item/2202w8bh

Josselson, R., Lieblich, A., \& McAdams, D. P. (2003). Up close and personal: The teaching and learning of narrative research (1st ed.). Washington. American Psychological Association. doi:10.1037/10486-000

Kahlo F., (1952). Frida Kahlo Quotes to Inspire You to Turn Pain into Beauty. Goalcats. https://www.goalcast.com/2017/11/28/17-frida-kahlo-quotes/

Kaur, R. (2016). Milk and honey. Kansas City, MO: Andrews McMeel Publishing.

Langer, C. L. \& Furman, R. (2004). Exploring identity and assimilation: Research and interpretive poems. Forum Qualitative Research. Levinger, G. (1992). Close relationship loss as a set of inkblots. In T.L. Orbuch (Ed.). Close relationship loss. New York: Bantam.

Lau, A. P. (2008). Invisible visible minorities: The experiences of racial minority teacher candidates on practicum and in teacher education programs. Queen University. https://www.collectionscanada.gc.ca/obj/thesescanada/vol2/OKQ/TC-OKQ-1402.pdf

Louie, B. L. (2013). Application of a grief model and Buddhist psychology in dealing with grieving, loss, and suffering. ProQuest Dissertations \& Theses Global. (1346190763). 
Martin, P. (2008). Global and U.S. immigration: Patterns, issues, and outlook. CLAS Policy Paper 7. Berkeley, CA: Center for Latin American Studies, University of California, Berkeley. http: hescholarship.org/uc/item/ 97m259nk

Meagher, G., \& Parton, N. (2004). Modernising social work and the ethics of care. Social Work \& Society, 2(1).

Mendez-Luck, C. A., \& Anthony, K. P. (2016). Marianismo and caregiving role beliefs among U.S.-born and immigrant Mexican women. The Journals of Gerontology. Series B, Psychological Sciences and Social Sciences, 71(5), 926-935. doi:10.1093/geronb/gbv083

Moffatt, K., Todd, S., Barnoff, L., Pyne, J., Panitch, M., Parada, H., Hunter Young, N. (2018). Worry about professional education: Emotions and affect in the context of neoliberal change in postsecondary education. Emotion, Space and Society, 26, 9-15. doi: 10.1016/j.emospa.2017.10.006

Moffatt, K. J. (2019). Postmodern social work; reflective practice and education. Columbia University Press. doi:10.7312/moff12800

Montoya, M. E. (1994). Mascaras, Trenzas, y Greñas: Un/Masking the Self While Un/Braiding Latina Stories and Legal Discourse. Chicana/o Latina/o Law Review, 15(1).

Moya, E. M., Chávez-Baray, S. M., Esparza, O., Calderon, L., Castañeda, E., Villalobos, G.,(2016). Ulysses syndrome in economical and political migrants in Mexico and the united states. Equidad. Revista Internacional De Políticas De Bienestar y Trabajo Social, (5), 11-50. doi:10.15257/ehquidad.2016.0001

Mucina, M. K. (2019). Spirituality and a Search for Home: The Complexities of Practising Sikhism on Indigenous Land. In Decolonizing the Spirit in Education and Beyond (pp. 23-43). Palgrave Macmillan, Cham. 
Ng, R. (1995). Teaching against the grain: Contradictions and possibilities. In R. Ng, P. Staton \& J. Scane (Eds.), Anti-racism, feminism, and critical approaches to education (pp. 129-152). Westport, CT: Bergin \& Garvey.

Nuñez,. A., González, P., Talavera, G. A., Sanchez-Johnsen, L., Roesch, S. C., Davis, S. M., . . Gallo, L. C. (2016). Machismo, marianismo, and negative cognitive-emotional factors: Findings from the hispanic community health Study/Study of latinos sociocultural ancillary $\begin{array}{llll}\text { study. Journal of } & \text { Latinx } & \text { Psychology, } & \text { 4(4), }\end{array}$ doi:http://dx.doi.org.ezproxy.lib.ryerson.ca/10.1037/lat0000050

Olmos, D. (2019). Racialized immigration and autonomy of migration perspectives: New directions and opportunities. Sociology Compass, 13(9), n/a. doi:10.1111/soc4.12729

Ortiz, M. (2017). Understanding the experience of immigration among adult Mexican-born males living in the united states: An exploration of grief, loss, and coping. ProQuest Dissertations Publishing. Retrieved from: https://search-proquestcom.ezproxy.lib.ryerson.ca/docview/1943411331?pq-origsite=summon

Ortiz, L. (2018). Social work with Latinos: Social economic, political and cultural perspectives Routledge. doi:10.1080/08841233.2018.1475789

Patterson, Haley. (2017). "A Sociolinguistic Survey of "Latinx". Honors Theses. 14. $\underline{\text { https://digitalcommons.northgeorgia.edu/honors theses/14 }}$

Parkes, C.M. (1988). Bereavement as a psychosocial transition: Processes of adaptation to change. Journal of social issues, 44, 53-65.

Perreira, K. M., \& Ornelas, I. (2013). Painful passages: Traumatic experiences and post-traumatic stress among U.S. immigrant Latino adolescents and their primary caregivers. The International Migration Review, 47(4), 976-1005. doi:10.1111/imre.12050 
Perez, R. M., \& Arnold-Berkovits, I. (2018). A conceptual framework for understanding Latino Immigrant's ambiguous loss of homeland. Hispanic Journal of Behavioral Sciences, 40(2), 91-114. doi:10.1177/0739986318761058

Perez Huber, L. (2010). Using Latina/o critical race theory (LatCrit) and racist nativism to explore intersectionality in the educational experiences of undocumented Chicana college students. Educational Foundations, 24(1-2), 77.

Perez Huber, L., \& Cueva, B. M. (2012). Chicana/Latina testimonios on effects and responses to microaggressions. Equity \& Excellence in Education, 45(3), 392-410.

doi:10.1080/10665684.2012.698193

Pérez Huber, L., \& Solorzano, D. G. (2015). Visualizing everyday racism: Critical race theory, visual microaggressions, and the historical image of Mexican banditry. Qualitative Inquiry, 21(3), 223-238. doi:10.1177/1077800414562899

Perruchoud R., Redpath-Cross, J., (2011). International Migration Law. IOM International Organization for Migration. Glossary on Migration NO 25.2nd Edition. ISSN 1813-2278 Retrieved from: http://www.iom.int

Perry, M. J. (2010). Colombian immigrants and their process of migratory grief. California Institute of Integral Studies. ProQuest Dissertations Publishing. Retrieved from: https://cas.ryerson.ca/login?service=http $\% 3 \mathrm{a} \% 2 \mathrm{f} \% 2 \mathrm{fezproxy}$. lib.ryerson.ca $\% 2 \mathrm{flogin} \% 3 \mathrm{fq}$ url\%3dezp.2aHR0cHM6Ly9zZWFyY2gucHJvcXVlc3QuY29tL2RvY3ZpZXcvYzMTk1 NTIwP3BxLW9yaWdzaXRIPXN1bW1vbg

Piirto, J. (2002). The question of quality and qualifications: Writing inferior poems as qualitative research. Qualitative Inquiry, 15(4), 431-446 
Potts, K., \& Brown, L. (2005). Becoming an Anti-Oppressive Researcher. In L. Brown \& S. Strega (Eds.), Research as Resistance: Critical, Indigenous and Anti-oppressive Approaches (pp. 255-286). Canadian Scholars’ Press.

Portes A., MacLeod D., (1996) What shall I call myself? Hispanic identity formation in the second generation. Ethnic and Racial Studies.19:523-547.

Raffaelli, M., \& Ontai, L. L. (2004). Gender socialization in Latino/a families: Results from two retrospective studies. Sex Roles, 50(5), 287-299

doi:10.1023/ B: SERS.0000018886.58945.06

Rando, T.A. (1993). Treatment of complicated mourning. Champaign: IL: Research.

Renfroe, S.J., (2018). The Lives of Undocumented Latina Migrants: An Intersectional Analysis of Gender, Nationality, and Migration Status in the United States. Rollins College. Honors Program Theses. 68. Retrieved From: https://scholarship.rollins.edu/honors/68

Rapport, Frances (2008). The poetry of Holocaust survivor testimony: Towards a new performative social science. Qualitative Social Research, 9(2), Art. 28, http://nbnresolving.de/urn:nbn:de:0114-fqs0802285

Sakamoto, I. (2007). Forum invited papers]: An Anti-Oppressive Approach to Cultural Competence. Canadian Social Work Review, 24(1), 105-114. Retrieved from: http://ezproxy.lib.ryerson.ca/login?url=https://search-proquestcom.ezproxy.lib.ryerson.ca/docview/210106770?accountid=13631

Salinas, C. (2020). The complexity of the "x" in latinx: How Latinx/a/o students relate to, identify with, and understand the term latinx. Journal of Hispanic Higher Education, 19(2), 149-168. doi:10.1177/1538192719900382 
Sanchez, D., Vandewater, E. A., \& Hamilton, E. R. (2017;2019;). Examining marianismo gender role attitudes, ethnic identity, mental health, and substance use in Mexican American early adolescent girls. Journal of Ethnicity in Substance Abuse, 18(2), 319-342. doi:10.1080/15332640.2017.1356785

Sands, R. G., \& Nuccio, K. (1992). Postmodern feminist theory and social work. Social Work. 37(6), 489-494. doi:10.1093/sw/37.6.489

Santos, J., (2019). Acculturation Stress and Ethnic Discrimination among Latinx Adolescent Clients in the Current Political Climate: A Qualitative Study of Mental Health Clinicians' Perspectives. College of Saint Elizabeth, ProQuest Dissertations Publishing 27548153.

Schoulte, J. C. (2011). Bereavement among African Americans and Latino/a Americans. Journal of Mental Health Counseling, 33(1), 11-20. doi:10.17744/mehc.33.1. r4971657p7176307

Smith, G. (1966). Communication and culture (Ed.). New York: Holt, Rinehart and Winston.

Stefancic, J. (1997). Latino and Latina critical theory: an annotated bibliography, La Raza Law journal, 10, 423-498. doi:10.15779/Z38Z37Q

Solheim, C., Zaid, S., \& Ballard, J. (2016). Ambiguous loss experienced by transnational Mexican immigrant families. Family Process, 55(2), 338-353. doi:10.1111/famp.12130 Retrieved form: https://doi-org.ezproxy.lib.ryerson.ca/10.1111/famp.12130

Solomon, R. P., Portelli, J. P. , Daniel, B. J., \& Campbell, A. (2005). The discourse of denial: How white teacher candidates construct race, racism and 'white privilege'. Race, Ethnicity and Education, 8, 147-169.

Solorzano, D. G., (1998). Critical race theory, race and gender microaggressions, and the experience of Chicana and Chicano scholars. International Journal of Qualitative Studies in Education, 11(1), 121-136. doi:10.1080/095183998236926 
Solorzano, D. G., \& Bernal, D. D. (2001). Examining transformational resistance through a critical race and LatCrit theory framework: Chicana and Chicano students in an urban context. Urban Education, 36(3), 308-342. doi:10.1177/0042085901363002

Solorzano, D., \&Yosso, T. (2000). Toward a critical race theory of Chicana and Chicano education. In C. Tejeda, C. Martinez, Z. Leonardo, \& P. McLaren (Eds.), Demarcating the border of Chicana(o)/Latina(o) education (pp. 35-65). Cresskill, NJ: Hampton.

Statistics Canada. (2001). The Latin American Community in Canada. Retrieved from: http://www.statcan.gc.ca/pub/89-621-x/2007008/t/4123249-eng.htm

Statistics Canada. (2011). National Household Peel Region and the Greater Toronto Area. Retrieved from: http://www12.statcan.gc.ca/nhs-enm/2011/dp-pd/prof/index.cfm

Stevens, E. P. (1973). Machismo and Marianismo. Society, 10(6), 57-63. doi:10.1007/BF02695282

Stroebe, M. S., \& Blink, E. v. d. (2008). Handbook of bereavement research and practice: Advances in theory and intervention (1st ed.). American Psychological Association. doi:10.1037/14498-000

Stroebe, M. S., \& Schut, H. (2010). The dual process model of coping with bereavement. : A decade on. Omega: Journal of Death and Dying, 61(4), 273-289. doi:10.2190/OM.61.4.b

Stroebe, M., Schut, H., \& Nauta, M. (2016). Is home-sickness a mini-grief? development of a dual process model. Clinical Psychological Science, 4(2), 344-358.

Stroebe, M., Schut, H., \& Boerner, K. (2017). Cautioning health-care professionals: Bereaved persons are misguided through the stages of grief. Omega: Journal of Death and Dying, 74(4), 455-473. doi:10.1177/0030222817691870 
Stroebe, M., Van Vliet, T., Hewstone, M., \& Willis, H. (2002). Homesickness among students in two cultures: Antecedents and consequences. British Journal of Psychology, 93, 147-168. http://dx.doi.org/10.1348/000712602162508

Taylor, P., Lopez, M. H., Martinez, J. H., \& Velasco, G. (2012). When labels don't fit: Hispanics and their views of identity. Pew Hispanic Center.

Tronto, J. C. (2010). Creating caring institutions: Politics, plurality, and purpose. Ethics and Social Welfare, 4(2), 158-171. doi:10.1080/17496535.2010.484259.

Umebinyuo I., (n.d.) "So, here you are too foreign ..." Quotes. Goodreads. Retrieved from: https://www.goodreads.com/quotes/7664973-so-here-you-are-too-foreign-for-home-tooforeign

Valdes, F., (1997). Foreword: Under Construction- LatCrit Consciousness, Community, and Theory. La Raza Law Journal. California Law Review, Vol. 85, No. 5. Retrieved from: https://www.jstor.org/stable/i276970

Vazquez, C., Dinelia, R., (2011). Grief therapy with Latinos: Integrating culture for clinicians. New York: Springer Publishing Company.

Vega, M. C. V. (2011). Yo cuento Latin American immigrant children tell their stories. Ryerson University. Master of Arts Immigration and Settlement Studies. Retrieved from: https://digital.library.ryerson.ca/islandora/object/RULA\%3A622

Villa, M.L., Cuellar, J., Gamel, N., \& Yeo, G. (1993). Aging and Health: Hispanic American Elders (2nd edition), SGEC Working Paper Series, Number 5, Stanford Geriatric Education Center.

Walter, C. A., \& McCoyd, J. L. (2009). Grief and loss across the lifespan: A biopsychosocial perspective. p.16. New York: Springer. http://dx.doi.org/10.1080/03906700601129798 
Walter, T., (2007). Modern grief, postmodern grief. International. Review of Sociology, 17 (1). pp. 123-134. ISSN 0390-670. Retrieved from:

Wakeman, B. E. (2015). Poetry as research and as therapy. Transformation (Exeter), 32(1), 50-68. doi:10.1177/026537881453776

Worden, J. W. (1982). Grief counseling and grief therapy: A handbook for the mental health practitioner Springer.

Yosso, T. J. (2005). Whose culture has capital? A critical race theory discussion of community cultural wealth. Race Ethnicity and Education, 8(1), 69-91. doi:10.1080/1361332052000341006

Yosso, T. (2006). Critical race counter-stories along the Chicana/Chicano educational. New York: Routledge. ISBN 0415951968, 9780415951968.

Young, A. A., Jr. (2004). Experiences in ethnographic interviewing about race: The inside and outside of it. In M. Bulmer \& J. Solomos (Eds.), Researching race and racism (pp. 187202). NewYork: Routledge.

Zea, M. C., Quezada, T., \& Belgrave, F. Z. (1994). Latino cultural values: Their role in adjustment to disability. Journal of Social Behavior and Personality, 9(5), 169.

Zambo, R., \& Zambo, D. (2013). Using I poems to hear the voices and understand the actions of EdD students conducting action research. The Qualitative Report, 18(84), 1-17. 